Final Report

\title{
GEOTHERMAL RESOURCE ANALYSIS AND STRUCTURE OF BASIN AND RANGE SYSTEMS, ESPECIALLY DIXIE VALLEY GEOTHERMAL FIELD, NEVADA
}

\author{
By \\ David D. Blackwell, Kenneth W. Wisian, Maria C. Richards, \\ Mark Leidig, Richard Smith, and Jason McKenna \\ Department of Geological Sciences \\ Southern Methodist University \\ Dallas, Texas 75275-0395
}

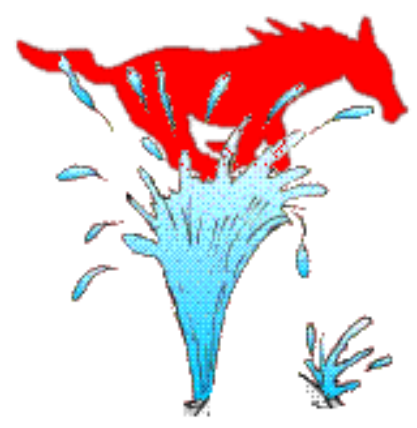

June 2003

Prepared for the U.S. Department of Energy, Under DOE Idaho Operations Office Financial Assistance award DE-FG07-01ID13886.

COPYRIGHT NOTICE The submitted manuscript has been authored by a contractor of the U.S. government under DOE contract DE-FG07-01ID13886. Accordingly, the U.S. Government retains a nonexclusive, royalty -free license to publish or reproduce the published form of this contribution, or allow others to do so, for U.S. Government purposes. 


\section{Table of Contents}

1. The SMU Geothermal Outlook-Introduction...............................................

2. Potential Ranking of Undeveloped Geothermal Systems in Nevada.............................4

3. Heat Loss - A Diagnostic Geothermal Resource Property ................................ 15

4. Regional Geophysics of Dixie Valley -

Example of A Large Basin and Range Geothermal Resource.............................21

5. Shallow Characteristics of Geothermal Systems -

Why Basin and Range Systems are Hard to Find....................................

6. Exploration Development Techniques For Basin and Range Geothermal Systems..................34

7. Insights Into Extensional Geothermal Systems from Numerical Modeling......................42

8. Construction and Explanation of the 2002 Geothermal Resource Potential Map..................50

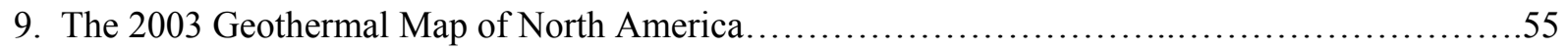

10. Data Sources and Resources:

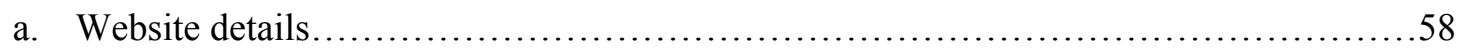

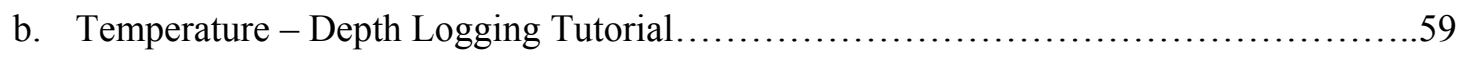

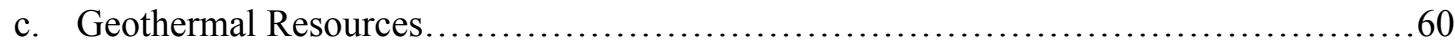

d. References...............................................................60

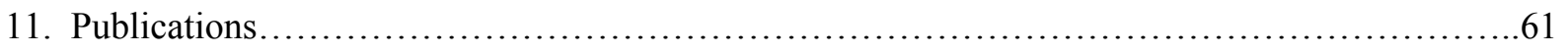




\section{Summary of Technical Results}

- Published new thermal and drill data from the Dixie Valley Geothermal Field that affect evaluation of Basin and Range Geothermal Resources in a very major and positive way

- Completed new geophysical surveys of Dixie Valley including gravity and aeromagnetics and integrated the geophysical, seismic, geological and drilling data at Dixie Valley into local and regional geologic models

- Developed natural state mass and energy transport fluid flow models of generic Basin and Range systems based on Dixie Valley data that help to understand the nature of large scale constraints on the location and characteristics of the geothermal systems

- Documented a relation between natural heat loss for geothermal and electrical power production potential and determined heat flow for 27 different geothermal systems

- Developed and published on the WWWeb a data base including information from over 5,900 geothermal exploration wells for Industry and Government use. Published a series of articles in the Geothermal Resources Council Bulletin describing the information available in the data base, the uses of the data and the implications to geothermal exploration and evaluation in the Basin and Range

- $\quad$ Prepared data set for generation of a new geothermal map of North America including industry data totaling over 25,000 points in the US alone. 


\section{Section 1. The SMU Geothermal Outlook-Introduction}

\subsection{Executive Summary}

The following chapters in this report summarize the research completed over the 3 years of this DOE contract. Articles were published in the Geothermal Resources Council Bulletin, GRC Transactions, the Stanford Geothermal Reservoir Engineering Workshops, and the World Geothermal Congress Proceedings. These articles discuss regional and site specific geothermal potential and exploration techniques for extensional geothermal systems increasing in scope from detailed studies of Dixie Valley, to the whole of the Basin and Range Province (encompassing all or part of the states of Nevada, California, Idaho, Montana, Oregon, Utah, Arizona, New Mexico and Texas). Also investigated were how to improve exploration techniques and development of a methodology for increasing the success of the next phase of exploration drilling in the region,. The final topics are related to maps produced using the information obtained from the research including the extensive data gathered from the DOE industry coupled data acquisitions of the 1980's. The Geothermal Resource Potential Map of United States developed as part of this research has successfully reached hundreds of users from our website and in publications (see Opportunities for Near-Term Geothermal Development on Public Lands in the Western United States published by DOE and BLM, and Renewable Energy Atlas of the West: A Guide to the Region's Resource Potential published by Land and Water Fund of the Rockies and NW Seed). A new "Geothermal Map of North American will be published in Fall 2003 by the American Association of Petroleum Geologists based primarily on the research described here.

Developers now regularly use the database for basic information as they evaluate geothermal projects. Although the economics are still tight, interest continues to grow to find methods for developing the geothermal resources in the United States. From home owners who would like to install heat pumps to developers wanting to install new power plants, the need to mine existing data to reduce geothermal discovery and exploitation costs is a common theme and has been addressed in this project.

To that end, the Southern Methodist University Geothermal Laboratory has collected and summarized all published temperature, gradient and heat flow data in the public domain, and made them freely accessible on our web site at: www.smu.edu/geothermal. Information provided in several of the following chapters is based on the SMU Western Geothermal Database and the Regional Heat Flow Database. Whether the research involves computer modeling of geothermal systems, interpretation of temperature and lithology logs, or interpretation of aeromagnetic data, the starting place is the synthesis of field data into interpretable data formats (databases). By learning from history, we believe that a better, less expensive and more consistent process for developing Basin and Range geothermal systems will benefit today's power plant and direct-use developers.

The basic thermal gradient data were collected over 15 years ago under a different development objective - large (multi-km square) areas with temperatures exceeding $200^{\circ} \mathrm{C}$. Most exploration effort at that time sought magma-related systems, because temperatures in extensional Basin and Range systems were thought to be usually less than $200^{\circ} \mathrm{C}$. Typical productive geothermal systems of the 1980's are primarily associated with areas where hydrothermal circulation is driven by cooling magma at shallow depths within the Earth. In these generally volcanic-related systems, temperatures can easily reach $300^{\circ} \mathrm{C}$, and have been found as high as about $500^{\circ} \mathrm{C}$. Temperature is usually not a problem for geothermal development in areas with magma-driven systems. The more important issues for geothermal developers are finding significant fluid flow in a chemically docile environment with safe locations for well fields and power plants. 
Even with minimal exploration activity between 1985 and 2000, understanding of extensional geothermal systems has changed, especially regarding deep fluid circulation in the absence of magmatism. In particular, recognition of temperatures exceeding $285^{\circ} \mathrm{C}$ in Dixie Valley (Blackwell et al., 2000), as shown in Chapter 6, Figure 6.1, p. 34, and continued successful exploitation and drilling in areas such as Steamboat, Beowawe and Dixie Valley, has increased past estimates of potential resources associated with deep fluid circulation systems. Many areas in Nevada are now known to exceed $200^{\circ} \mathrm{C}$ in temperature. Even this temperature is no longer a limiting factor with the demonstrated competitiveness of binary systems operating at temperatures on the order of $150^{\circ} \mathrm{C}$.

U.S. Geological Survey Circular 790 (Muffler, 1979) estimated geothermal potential based on system (reservoir) temperature, and assumed simplified parameters such as permeability and system (area) size. In the absence of drilling in most systems temperatures estimated for Basin and Range systems were dependent on having an appropriate sample of the deep fluids. Near-surface temperatures rarely exceed the boiling point $\left(\right.$ about $90^{\circ} \mathrm{C}$ ) and so are not a helpful indicator of actual temperatures at depth. Most Basin and Range systems available today for exploration have boiled or mixed water chemistry. Systems with clear, high-temperature geochemical signatures were drilled long ago (Benoit and Butler, 1982; Mariner et al, 1983; Edmiston and Benoit, 1984).

Dixie Valley, Nevada, the largest and hottest known nonmagnatic system, was not one of the high-temperature systems identified in the past by fluid geochemistry. In the absence of this method, or in cases where water samples are not suitable for reliable geothermometry, a positive criterion is to find high temperatures at shallow depths. We believe that shallow temperatures of greater than $80^{\circ} \mathrm{C}$ are generally found only where temperatures exceed $150^{\circ}$ at depths of $1-2 \mathrm{~km}$. So deeper temperatures will likely be at least on the order of $150^{\circ} \mathrm{C}$ in many of the areas in the Great Basin that were "left for future exploration." Resource assessment, using the new database information with multiple criteria, characterized 44 areas with geothermal exploration potential in Nevada alone.

A negative aspect to this type of exploration is the expense and difficulty of drilling a deep test well - especially when it misses the targeted flow region. Lack of understanding of shallow temperature-depth curves was a contributing factor to mislocation of many 1970-1980 vintage deep exploration wells. The best documented case is the B29-1 well at Desert Peak, where the surface casing was set at $365 \mathrm{~m}$ through the anomaly zone at about $275 \mathrm{~m}$, and the well drilled on to $2,440 \mathrm{~m}$ before completion of the well was attempted! Subsequent intermediate depth drilling located an upflow zone feeding the shallow aquifer, resulting in a highly successful geothermal development (Benoit et al., 1982). Increased understanding of the controls on temperature behavior in wells of all depth ranges is a positive asset to the next generation of exploratory drilling in the Basin and Range and has been addressed in this research.

Obviously, there is plenty of need for new drilling. New temperature gradient and conductivity data will expand the number of known geothermal areas. But the emphasis of this project was, before expensive new data collection, to revisit some of the known areas in the Basin and Range with improved concepts and insights after this long hiatus in activity. Toward this goal, we have compiled available thermal-gradient exploration data (Blackwell, 2001, web site noted above). 


\subsection{References}

Benoit, Walter R. and Rovert W. Butler, 1982. "A Review of High-Temperature Geothermal Developments in the Northern Basin and Range Province," Geothermal Resources Council Special Report 13, pp. 57-80.

Blackwell, D.D., B. Gollan, and D. Benoit, 2000. "Temperatures in the Dixie Valley, Nevada Geothermal System," Geothermal Resources Council Transactions, v.24, pp. 223-228.

Edmiston, R.C. and W.R. Benoit, 1984. "Characteristics of Basin and Range Geothermal Systems with Fluid Temperatures of $150^{\circ} \mathrm{C}$ to $200^{\circ} \mathrm{C}$," Geothermal Resources Council Transaction, v.8, pp. 417-424.

Mariner, R.H., T.S. Presser, and W.C. Evans, 1983. "Geochemistry of Active Geothermal Systems in the Northern Basin and Range Province," Geothermal Resources Council Special Report 13, pp. 95-119.

Muffler, L.J.P., ed., 1979. Assessment of Geothermal Resources of the United States-1978, U.S. Geological Survey Circular 790, 163p. 


\section{Section 2: Potential Ranking of Undeveloped Geothermal Systems in Nevada}

\subsection{Introduction}

The objective in this chapter is to discuss and provide information relevant to exploration for and utilization of geothermal energy in the Basin and Range Province, primarily in Nevada. Southern Methodist University Geothermal Laboratory collected thermal gradient/heat flow exploration reports from AMAX, Aminoil USA, Anadarko Petroleum, Chevron, Earth Power Production Co., Ensearch, Getty Oil, Gulf, Hunt, NuFuels, Oxy Geothermal, Phillips, Sunoco, Southland Royalty, TransPacific Geothermal, and Union Geothermal.

Data have also been compiled from the U.S. Geological Survey Great Basin database (Sass, 2001), the Nevada Bureau of Mines and Geology (Garside, 1997), the DNAG map of North America (Blackwell et al., 1991), and other published sources. These thermal data have been compiled into a single, Western Geothermal Database (WGD), now available online at www.smu.edu/geothermal.

The WGD is the source for information presented in this chapter. The majority of geothermal wells in the database are densely arrayed in the northcentral portion of Nevada, the Snake River Plains in Idaho, the Basin and Range eastern boundary in Utah, and the central Cascades in Oregon (Figure 2.1). The lowest density of wells is in southern Nevada and northwest Arizona, central Idaho and central Oregon. There are over 5000 individual geothermal well locations in the WGD.

The majority of collected data listed above is from the 1970s and 1980s, because of a dearth in drilling for geothermal exploration purposes in the 1990s. Hopefully, funding by DOE to produce easily accessible databases, along with their current funding of the GeoPowering the West Program, will spur renewed interest in geothermal exploratory drilling. Because of the many exploration locations and different methods used in the past, some areas have received more attention than others. We will review geothermal areas that are not usually discussed and describe a new way of comparing data between these areas.

\subsection{Data Review of Geothermal Areas}

Although the WGD covers all of western United States, Nevada is the focus of this report. Much of the emphasis in published reports and papers of the past was on examining Basin and Range power plant sites (Cove Fort, Desert Peak, Dixie Valley, Roosevelt, Soda Lake, Steamboat and Stillwater) or better known undeveloped geothermal areas (Blue Mountain, Borax Lake, Buffalo Valley, Buena Vista Valley, Drum Mountains, Fireball Ridge, Fish Lake Valley, Glass Buttes, Grass Valley, Humboldt House, McCoy, North Valley, Pirouette Mountain, Ruby Valley, Rye Patch, Surprise Valley, Tuscarora and Warner Valley, and others). However, numerous other areas from the prior exploration phase have potential for geothermal exploration and development. (Fig.2.2)

Working with the WGD and its $5000^{+}$wells led to development of a simple method for examination and comparison of the numerous geothermal areas. Because each area seems to have its own set of qualities and available data, the goal was to find a way to "even the playing field." This was necessary because within the WGD there are single well locations that seem to have as much merit as geothermal areas with many thermal gradient wells. Using a ranking scale converted to pie charts provides a useful visual technique for comparison of very different sets of data. 


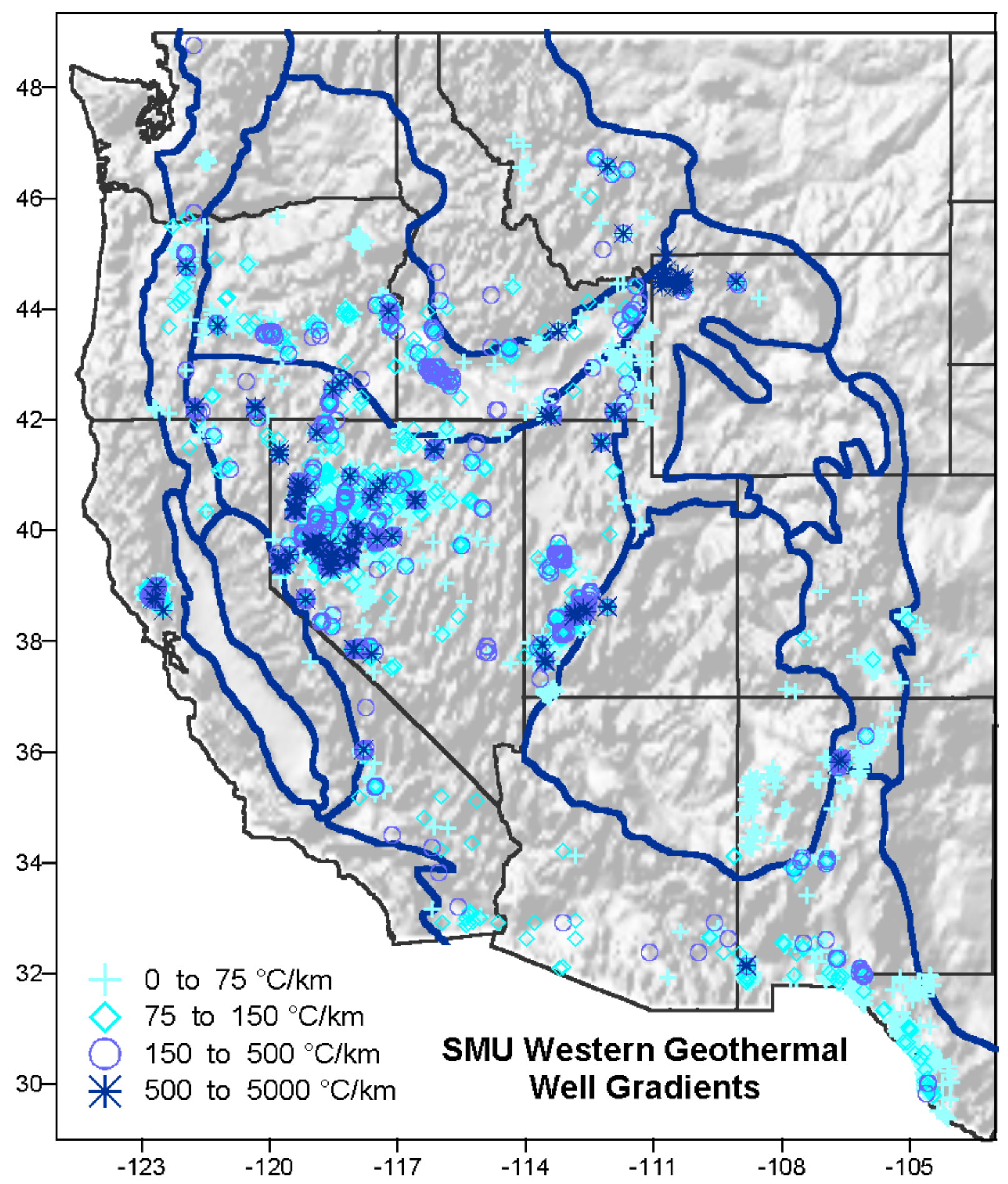

Figure 2.1. Location of wells listed in the SMU Western Geothermal Database www.smu.edu/geothermal. 


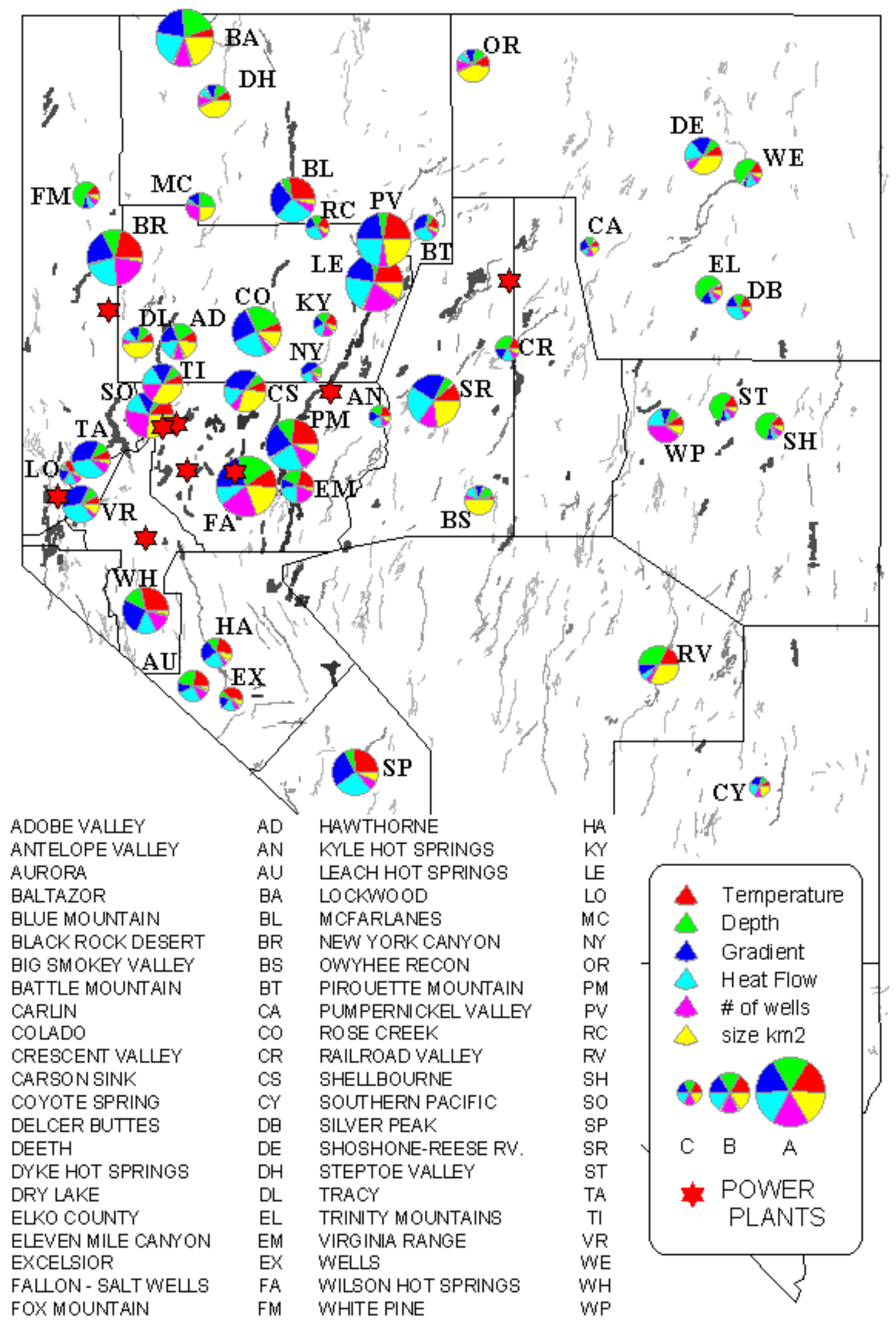

Figure 2.2. Geothermal prospects with parameter weighting and faults. 
To be considered for our study, Nevada geothermal areas had to possess either a minimum well temperature of $100^{\circ} \mathrm{C}$ or a minimum heat flow of $150 \mathrm{~mW} / \mathrm{m}^{2}$. In our view, choosing these two parameters focuses attention on geothermal areas where there is potential to reach a target temperature for power generation of $>150^{\circ} \mathrm{C}$. Each area was ranked on a scale of A through D for six parameters that are the basis of the pie charts shown in Figure 2.2 and explained in Table 2.1, including maximum temperature, maximum well depth, temperature gradient, heat flow, number of wells drilled, and size of known area with heat flow over $150 \mathrm{~mW} / \mathrm{m}^{2}$. These six parameters were chosen because of a similar amount of data for each that is available in the WGD.

Table 2.1. The top 15 areas with overall A-B rankings shown in Figure 2.2.

\begin{tabular}{|l|c|c|c|c|c|c|c|c|}
\hline AREA NAME & $\begin{array}{l}\text { ABR } \\
\text { V. }\end{array}$ & $\begin{array}{l}\text { MA } \\
\text { X. } \\
\text { TEM } \\
\text { P. }\end{array}$ & $\begin{array}{l}\text { MAX } \\
\text { DEP } \\
\text { TH }\end{array}$ & $\begin{array}{l}\text { GRA } \\
\text { D- } \\
\text { IEN } \\
\text { T }\end{array}$ & $\begin{array}{l}\text { HEA } \\
\text { T } \\
\text { FLO } \\
\text { W }\end{array}$ & $\begin{array}{l}\text { \# OF } \\
\text { WEL } \\
\text { LS }\end{array}$ & $\begin{array}{l}\text { ARE } \\
\text { A } \\
\text { SIZE }\end{array}$ & $\begin{array}{l}\text { TOT } \\
\text { AL } \\
\text { POIN } \\
\text { TS }\end{array}$ \\
\hline Fallon Navel Air Station & BR & A & B & A & A & A & A & 88 \\
\hline Leach Hot Springs & LE & A & A & A & B & A & A & 80 \\
\hline Baltazor & BA & C & A & A & A & A & B & 76 \\
\hline Pumpernickel Valley & PV & A & C & A & A & C & A & 76 \\
\hline Blue Mountain & BL & A & C & A & A & A & D & 70 \\
\hline Shoshone-Reese River & SR & B & C & A & A & B & A & 68 \\
\hline Pirouette Mountain & PM & A & B & A & A & B & A & 68 \\
\hline Colado & CO & C & A & A & A & C & B & 64 \\
\hline Southern Pacific & SO & B & C & B & B & A & A & 60 \\
\hline Silver Peak & SP & A & C & A & A & C & C & 60 \\
\hline Wilsons Hot Springs & WH & A & B & A & B & B & D & 58 \\
\hline Carson Sink & CS & C & C & A & B & C & A & 52 \\
\hline Railroad Valley & RV & B & A & C & D & D & B & 44 \\
\hline Trinity Mountains & TI & C & C & B & B & B & B & 44 \\
\hline
\end{tabular}

It should also be noted that many past determinations of geothermal potential in the United States were from chemical geothermometers (Muffler, 1979). This information was not considered in this report because so many prime areas determined with this method have already been extensively drilled. The less explored areas discussed here are often composed of geothermal systems with fluid mixing between shallow and deep circulation paths, or boiling within them that makes their geochemical signatures inaccurate. Slices of the pie charts in Figure 2.2 for each area (or single well) were determined using the following criteria:

Maximum Temperature. This parameter was based on a projected maximum depth to the intersection of the $200^{\circ} \mathrm{C}$ isotherm. Temperatures reaching $200^{\circ} \mathrm{C}$ by 300 meters were ranked A; by 1,000 meters ranked B; by 3000 meters ranked C; and deeper than 3,000 meters ranked D.

Maximum Well Depth. Wells deeper than 1,000 meters ranked A; $>300$ meters ranked B; $>90$ meters ranked $\mathrm{C}$; and less than 90 meters ranked $\mathrm{D}$. 
Temperature Gradients. Temperatures $>500{ }^{\circ} \mathrm{C} / \mathrm{km}$ ranked A; $>300{ }^{\circ} \mathrm{C} / \mathrm{km}$ ranked $\mathrm{B} ;>100{ }^{\circ} \mathrm{C} / \mathrm{km}$ ranked $\mathrm{C}$; and $<100{ }^{\circ} \mathrm{C} / \mathrm{km}$ ranked $\mathrm{D}$.

Heat Flow. Heat flows greater than $800 \mathrm{~mW} / \mathrm{m}^{2}$ ranked A; $>400 \mathrm{~mW} / \mathrm{m}^{2}$ ranked $\mathrm{B} ;>200 \mathrm{~mW} / \mathrm{m}^{2}$ ranked $\mathrm{C}$; and $>200 \mathrm{~mW} / \mathrm{m}^{2}$ ranked $\mathrm{D}$.

Number of Wells. Areas with wells $>50$ ranked A; $>30$ ranked B; and $>10$ ranked C. Many areas were assigned a D ranking because only one "discovery" well was drilled.

Size of Known Area Over $150 \mathbf{~ m} / \mathbf{W m}^{2}$. Calculating areas that fell within an approximated 150+ $\mathrm{m} / \mathrm{Wm} 2$ contour determined this parameter. Areas with only one well or too few to determine the extent of the "known" area were ranked D. Remaining areas that were greater than $200 \mathrm{~km}^{2}$ ranked A; $>120 \mathrm{~km}^{2}$ ranked $\mathrm{B}$; and $>50 \mathrm{~km}^{2}$ ranked $\mathrm{C}$.

From these criteria, each slice of the pie shown for various areas in Figure 2.2 was given a numerical value of $\mathrm{A}=16 ; \mathrm{B}=8 ; \mathrm{C}=4$; and $\mathrm{D}=2$. With these valuations, a perfect site would earn 96 points, or 16 points for each slice of its pie chart - the maximum possible score if all six categories received A rankings. This method helps de-emphasize an area with only one very strong parameter. Single wells and areas were compared with one another to evaluate their strengths and weaknesses. Of the 50 areas ranked, none received a 96-point score. Fifteen fell within the A-B average range, 22 within the $\mathrm{B}-\mathrm{C}$ range, and 13 within the $\mathrm{C}-\mathrm{D}$ range.

The top 44 geothermal areas are shown in Figure 2.2. Each is shown with its representative pie categories, according to its parameter ranking and composite score. For example, Owyhee Recon (OR at the top of Figure 2.2) has an "A" rating in size of geothermal area, while its other five categories have " $C$ " rankings represented by equal pie slices. The overall pie size shows the area has a ranking between "B" and "C."

In comparing the pie chart locations and sizes in Figure 2.2, the northwestern portion of Nevada is identified with the most known potential for further exploration. It is significant that except for the vicinity of the Nevada Test Site vicinity and the southern tip of Nevada, there is potential for further geothermal exploration throughout Nevada. In a 1982 low temperature assessment of geothermal resources in the western United States (Mariner, 1983), Nevada has a fairly even distribution of isolated systems and delineated areas. If more drilling had originally occurred in eastern Nevada or along the California border, these areas would almost certainly have a greater density of potential geothermal areas today.

\subsection{Specific Parameter Discussion}

When looking for viable areas to develop geothermal energy resources, there are obvious advantages to having information on each of the six parameters used for the pie charts shown in Figure 2.2. In geothermal exploration the saying, "A little knowledge is a dangerous thing," can also be true. At times, certain parameters can be deceiving. The following discussion is meant to foster better understanding of the six parameters used for this study and how to use each one constructively.

Temperature. If the geothermal exploration goal is to find new flash power plant locations, then fluid temperature must be approximately $150^{\circ} \mathrm{C}$ within approximately one $\mathrm{km}$ depth. If the goal is to use the geothermal resource for binary power plants or direct uses such as spas, fish farms, or other industries, 
cooler temperatures are satisfactory. One of the first problems with using temperature as a determining factor is that borehole logs done by a driller often either estimate or does not list a bottom hole temperature. When temperature data are available for an area, the first step is understanding what is considered above average to high temperatures for an area. A map of average shallow groundwater temperatures by Gass (1982) can be found on the Internet at: www.smu.edu/geothermal. It can be used to determine background surface ground temperatures. Temperatures in geothermal areas can be very hot at very shallow depths, i.e., Leach Hot Springs, with a temperature of $112^{\circ} \mathrm{C}$ at 17 meters (Sorey and Olmsted, 1994). Temperatures can also be geothermally cold in deep wells, i.e. Elko County's Franklin well with a maximum temperature of $137^{\circ} \mathrm{C}$ at almost $4 \mathrm{~km}$. One pattern can be positive in shallow boreholes, then negative in deeper wells. Wells drilled in the Pirouette Mountain area, an extension of Dixie Valley at the southern end of the valley, illustrate this situation. Hunt Oil Co. drilled 45 wells in 1979 and 1980 to varying depths up to 613 meters. The exploration's 150-meter well temperatures were the same as neighboring deeper wells, ranging from $58^{\circ}$ to $82^{\circ} \mathrm{C}$. At the nearby Eleven Mile Canyon geothermal area, temperature-depth curves were similar to what most people would expect, with temperatures starting at $30^{\circ}$ to $35^{\circ} \mathrm{C}$ at 150 meters, then warming to $77^{\circ}$ to $80^{\circ} \mathrm{C}$ in the two deep wells, at 610 and 613 meters (Hunt, 1999). In reviewing well temperatures, it is important to understand the geologic structure of the system, and to know how to read temperaturedepth curves. This helps to localize the zone of hot fluid that might otherwise be missed. Geothermal areas in Figure 2.2 that have a temperature ranking of "A" (projected at approximately $200^{\circ} \mathrm{C}$ by 300 meters) include Black Rock Desert, Blue Mountain, Leach Hot Springs, Pirouette Mountain, Pumpernickel Valley, Rose Creek, Silver Peak, and Wilson Hot Springs.

Gradients. The most common parameter provided in geothermal exploration reports is gradient. All wells listed in the WGD have at least one gradient value, and many have three or four listed per well. If there is upflow or downflow in a well, and the temperature-depth curve is misread, the gradient will give a misleading prediction of projected temperature. Wells with very high temperatures at shallow depths generally have the highest gradient $\left(500-10,000^{+}{ }^{\circ} \mathrm{C} / \mathrm{km}\right)$, while deep wells that are relatively hot may only have a gradient of $40^{\circ}$ to $160^{\circ} \mathrm{C} / \mathrm{km}$ at the bottom. Thus, depending on which gradient is chosen, geothermal area predictions can vary dramatically. The Baltazor Hot Springs geothermal area lies along the north end of Continental Lake. At 740 meters, its deepest well is 45-14, and provides a good example of how an area's geothermal prediction can vary according to where measurements are taken. Lateral groundwater movement at a depth of 67 meters is noticeable on the well's temperaturedepth curve. The upper gradient, from 240 to 400 meters, is $90^{\circ} \mathrm{C} / \mathrm{km}$. Transfer of hot fluid into the formation occurs in this interval. The next gradient, from 440 to 590 meters, is $155^{\circ} \mathrm{C} / \mathrm{km}$, and seems to be most representative of the geothermal system. The deepest gradient, from 590 to 650 meters, is the highest at $200{ }^{\circ} \mathrm{C} / \mathrm{km}$, yet is likely caused by convective heat transfer within the borehole itself (Williams and Helms, 1983). "A" rated areas for gradient $\left(500+^{\circ} \mathrm{C} / \mathrm{km}\right)$ in Figure 2.2 include: Baltazor, Black Rock Desert, Blue Mountain, Carson Sink, Colado, Fallon-Salt Wells, Hot Springs Ranch, Leach Hot Springs, Pirouette Mountain, Pumpernickel Valley, Shoshone-Reese River, Silver Peak, Tracy, and Wilson's Hot Springs.

Depth. This parameter has the most economic impact on geothermal exploration. The deeper the well is, generally the more expensive. During past explorations, only a few deep boreholes were drilled. One of the best examples is in Pumpernickel Valley, where soil mercury surveys of 130 samples of valley alluvium, 110 two-meter temperature probe tests, but only 10 boreholes ranging in depth from 5 to 91 meters were accomplished (Trexler et al., 1982). Another example lies north of the Desert Peak 
and Brady's Hot Springs power plants, where Phillips Petroleum explored for geothermal resources in the northwest portion of Churchill County and the southwest portion of Pershing County, but with boreholes drilled only to shallow to intermediate depths. Clustered from west to east these prospects include Fireball Ridge, Nightingale, North Valley, Granite Springs, Adobe Valley, Trinity Mountains and Southern Pacific (SASS, 2001a). Southern Pacific drilled 69 drilled additional boreholes in the areas ranging in depth from 23 to 91 meters, with a highest measured temperature of $46^{\circ} \mathrm{C}$ at 91 meters. These geothermal areas combined have approximately 140 shallow boreholes. The deepest well within this geothermal cluster of areas is in Adobe Valley, at 550 meters. It is difficult to predict the extent of a geothermal system when there are not enough deep wells that characterize the fluid flow of the area. The well location and analysis of the well $\log$ as it is drilled are equally important. Geothermal areas listed in Figure 2.2 with an "A" rating for total well depth (>1000 meters) include Baltazor, Colado, Fallon NAS, and Railroad Valley.

Heat Flow. To calculate heat flow, geothermal gradient and thermal conductivity value are multiplied together. Thermal conductivity can be determined in a laboratory using devices such as a divided bar on well core samples or cuttings. When working with the WGD, there are many wells that do not have thermal conductivity measurements, but do have lithology information. For these wells, we assigned a conductivity value to the samples following Sass (2001b), with clay-rich sediments $1.1 \mathrm{~W} / \mathrm{m} / \mathrm{K}$, and alluvium in valleys $1.4 \mathrm{~W} / \mathrm{m} / \mathrm{K}$. Once again, it is of utmost importance to choose the correct gradient - one that is most representative of the geothermal system-since it is used again in determining heat flow. In this scenario, if gradient is off then the error is compounded since it would show a distorted relationship in our pie charts for both gradient and heat flow. A geothermal area can have a range of heat flows. Background heat flow for Nevada is generally $80 \mathrm{~mW} / \mathrm{m}^{2}$. Heat flow above this value is considered characteristic of a geothermal system. Productive heat flows are generally greater than $150 \mathrm{~mW} / \mathrm{m}^{2}$. An example of how heat flow varies within a geothermal area is Black Rock Desert. The region has heat flows ranging from 50 to $>800 \mathrm{~mW} / \mathrm{m}^{2}$. It was speculated that the lower heat flow values were from recharge to the system, because the heat flows were found at the lowest topographic point and the area of deepest basin fill. The highest heat flow values were measured near the range-bounding faults (Mase and Sass, 1980). In the Shoshone-Reese River Valley, the influence of gradient on heat flow is apparent. There are a total of 52 relatively shallow boreholes in the area, averaging 89 meters deep. The strengths of this area for potential geothermal development are its high temperatures and gradients, averaging $225^{\circ} \mathrm{C} / \mathrm{km}$ with a maximum of $590^{\circ} \mathrm{C} / \mathrm{km}$. Maximum calculated heat flow is $1117 \mathrm{~mW} / \mathrm{m}^{2}$, which is quite high (Amax, 1998). Areas with the highest heat flows (800 $\mathrm{mW} / \mathrm{m}^{2}$ ) in Figure 2.2 include Baltazor, Black Rock Desert, Blue Mountain, Colado, Hot Springs Ranch, Leach Hot Springs, Pirouette Mountain, Pumpernickel Valley, Shoshone-Reese River, Silver Peak, and Tracy.

Number of Wells. The number of wells is helpful only if they are properly located and a variety of depths were drilled. Having a wide areal extent of drilled boreholes helps to determine the size of the geothermal area's shallow manifestation. However, as shown by the single wells highlighted in the next section, a few properly located boreholes or wells can discover new potential areas for geothermal exploration. A prime example of the point that more boreholes are not necessarily better is Leach Hot Springs. Temperature studies of Leach Hot Springs in Southern Grass Valley contain only one deep well (Aminoil USA 11-36), drilled to 2,600 meters and reaching a maximum temperature of only $125^{\circ} \mathrm{C}$ (Sorey and Olmsted, 1994). Though there are over 70 shallow wells in this geothermal area, there is still uncertainty about the system. Sorey and Olmsted (1994) conclude that there is 
considerable information describing the characteristics of the shallow hydrothermal system of Leach Hot Springs, but there is not enough knowledge about the possible extent of a high-temperature reservoir at depth that could support an electric power plant. Areas in Figure 2.2 with an "A" rating for number of wells $(>50)$ include Black Rock Desert, Leach Hot Springs, Southern Pacific, and White Pine.

Size of Known Area Over $150 \mathrm{~mW} / \mathrm{m}^{2}$. The size of a geothermal area with elevated heat flow is a useful parameter. The known area size helps to indicate which areas have been explored to a greater extent in the past. If one of the goals is to not reinvent the "geothermal wheel," then knowing where past exploration took place-regardless of success - is necessary. In determining the size of a geothermal area, one problem is determining the correct method of contouring the heat flow. Most of the time, heat flow contours are constructed to follow the topographic contours of the valley. The McCoy geothermal area contradicts this generalization, with the majority of boreholes drilled within the ranges. Another potential problem is not enough data. In this case, heat flow contours may connect over a much larger area than is correct. With only four wells, Railroad Valley has an elevated heat flow contour that connects them, even though the wells are located over a large distance and what lies in between is not fully known. There is also the difficulty of areas without heat flow calculations and with single point anomalies (given a "D" ranking in this report), which could be much larger once further explored. Areas that achieved an "A" rank in Figure 2.2 include Baltazor, Big Smoky Valley, Black Rock Desert, Carson Sink, Deeth, Dry Lake, Pirouette Mountain, Owyhee Recon, Pumpernickel Valley, Shoshone-Reese River, Southern Pacific, and Trinity Mountains.

\subsection{One Hit Wonders}

The following "areas" have only one to three wells associated with them: Antelope Valley (AD), Cresent Valley (CR), Elko County, (EL), Fox Mountain (FM), Lockwood (LO), Rose Creek (RC), Schellbourne (SH), and Steptoe Valley (ST). Like areas already discussed, these well sites had to have a calculated heat flow of over $150 \mathrm{~mW} / \mathrm{m}^{2}$ or a maximum temperature of over $100^{\circ} \mathrm{C}$ to be considered in this study. There is a lot of "wondering" that occurs when only one or two wells are drilled.

Looking at the spacing of single wells shows the randomness associated with exploration drilling, whether for geothermal, oil and gas, or other purposes. The "discovery" wells included in this study greatly range in depth, and the pie charts in Figure 2.2 are useful in comparing them. Scattered all over Nevada, these single-point "anomalies" represent the magnitude of possible geothermal sites still undiscovered. Starting near the center of the state, there are three wells in Antelope Valley. The deepest (LA-7) has a gradient of $152^{\circ} \mathrm{C} / \mathrm{km}$ at 149 meters depth. On the border between Lander and Eureka counties is Crescent Valley, with three thermal anomalies: Crescent Hot Springs, Crescent Fault, and a blind anomaly northeast of Crescent Fault. The windmill well has elevated shallow temperature, with a gradient of $147^{\circ} \mathrm{C} / \mathrm{km}$ at a depth of 34 meters. This area is just south of the Beowawe geothermal power plant. Heading south into White Pine County is Schellbourne, an oil well with temperatures as high as $198^{\circ} \mathrm{C}$ at 3,300 meters. Steptoe Valley lies next to it, with a temperature of $105^{\circ} \mathrm{C}$ at 1,954 meters. A well at Lockwood in western Nevada just east of Reno reached $34^{\circ} \mathrm{C}$ and a heat flow value of $232 \mathrm{~mW} / \mathrm{m}^{2}$ at 32 meters. Due north is Fox Mountain, with a well that found $104^{\circ} \mathrm{C}$ temperature at 1,201 meters. And finally, along the border of Pershing and Humboldt Counties, a well at Rose Creek measured $35^{\circ} \mathrm{C}$ at a medium depth of 116 meters. Schellbourne and Steptoe Valley seem to have potential. Although these single wells may be too cool for a power plant (by $3 \mathrm{~km}$ the water temperature should be near $250^{\circ} \mathrm{C}$ if power generation is the desired use), these are areas of 
elevated temperatures with an unknown source. The Lockwood well is an example of one needing more research. If well temperatures there continue to increase, it may reflect the capacity of nearby Steamboat Springs.

\subsection{Conclusion}

When reviewing previous geothermal exploration data, evaluation of all the different variables can be overwhelming. With so many parameters needed for consideration to determine whether or not an area is worthwhile for further exploration, it is important to choose the most appropriate parameters for comparison. Through weighting the data with A-D rankings, problems like shallow vs. deep temperatures can be balanced. Using pie charts, areas and their individual parameters can be easily compared. This can also be done within a single geothermal area to compare existing wells. Other parameters that can be added to the pie charts as desired or available, i.e., heat loss, conductivity, geochemical information, number of faults, and groundwater depth.

We didn't know initially how many "other" geothermal locations would meet our minimum criteria. To finish with the 44 areas that we still consider as potential geothermal prospects, was an exciting surprise. Another surprise was the geothermal potential of locations where only one well was drilled. Using the pie chart comparison method, most of them did better than areas with more data available. This leads us to believe that there are still many more geothermal areas yet to be discovered. In U.S. Geological Survey Circular 790 it was stated that within the Basin and Range, probably only about one-fifth of the total accessible resources base has been identified, (Brook, et al., 1978). With the lack of exploration drilling in the late-1980s and 1990s, this may still be true.

\subsection{References}

AMAX Inc., 1998 data release: "Shoshone, Nevada, gradient, BHT, heat flow and map for 17 wells."

Benoit, D., J.E. Hiner, and R.T. Forest, 1982. Discovery and Geology of the Desert Peak Geothermal Field: A Case History, Nevada Bureau of Mines Geological Bulletin, v. 97, 82 p.

Benoit, Walter R., and Robert W. Butler, 1982. "A Review of High-Temperature Geothermal Developments in the Northern Basin and Range Province," Geothermal Resources Council Special Report 13, pp. 57-80.

Blackwell, D. D., B. Gollan, and D. Benoit, 2000. "Temperatures in the Dixie Valley, Nevada Geothermal System," Geothermal Resources Council Transactions, v. 24, pp. 223-228.

Blackwell, D.D., J. L. Steele, L. S. Carter, 1991. "Heat Flow Patterns of the North American Continent: A Discussion of the DNAG Geothermal Map of North America," Geological Society of America Decade Map Volume 1, pp. 423-436, 1991.

Brook, C.A., R.H. Mariner, D.R. Mabey, J.R. Swanson, Marianne Guffanti, and L.J.P. Muffler, 1979. "Hydrothermal Convection Systems with Reservoir Temperatures $>90^{\circ} \mathrm{C}$," Assessment of Geothermal Resources of the United States - 1978, U.S. Geological Survey Circular 790, Muffler, L.J.P., ed, 163 p.

Edmiston, R.C., and W.R. Benoit, 1984. "Characteristics of Basin and Range Geothermal Systems with Fluid Temperatures of $150^{\circ} \mathrm{C}$ to $200^{\circ} \mathrm{C}$," Geothermal Resources Council Transactions, v. 8, pp. 417-424.

Fairbank, Brian D., and Howard P. Ross, 1999. "Geology and Temperature Gradient Surveys at the Blue Mountain Geothermal Discovery, Humboldt County, Nevada," Geothermal Resources Council Transactions, v. 23, pp. 513-517.

Garside, Larry J., 1997. Nevada Geothermal Gradient-Hole Database CD-ROM, prepared for Idaho National Engineering Laboratory Lockheed Idaho Technologies Co., Idaho Falls, ID. Contract 
No. C85-110656-005, Nevada Bureau of Mines and Geology, University of Nevada, Reno, Nevada.

Garside, Larry J., and Schilling, John H., 1979. Thermal Waters of Nevada, Nevada Bureau of Mines and Geology, Bulletin 91, $163 \mathrm{p}$.

Gass, T.E., 1982. "Geothermal Heat Pumps," Geothermal Resources Council Bulletin, v.11, pp. 3-8.

Hunt Oil Co. data release of Eleven Mile Canyon and Pirouette Mountain exploration drilling documents, 1999. Via Roger Bowers.

Lachenbruch, A.H., and J.H. Sass, 1977. "Heat Flow in the United States and the Thermal Regime of the Crust," The Earth's Crust, American Geophysical Union Geophysical Monograph Series, 20, J.G. Heacock ed., pp. 626-675.

Lachenbruch, A.H., and J.H. Sass, 1978. "Models of an Extending Lithosphere and Heat Flow in the Basin and Range Province," Cenozoic Tectonics and Regional Geophysics of the Western Cordillera, Geological Society of America Memoir 152, R.B. Smith and G.P. Eaton eds., pp. 209-250.

Lopez, D., L. Smith, and M.L. Sorey, 1994. "Modeling Fluid Flow and Heat Transfer at Basin and Range Faults: Preliminary Results for Leach Hot Springs, Nevada," Geothermal Resources Council Transactions, v. 18, pp. 11-16.

Mackelprang, Claron E., 1982. Interpretation of Geophysical Data from the Colado KGRA, Pershing County, Nevada, 27 p.

Mariner, R.H., T.S. Presser, and W.C. Evans, 1983. "Geochemistry of Active Geothermal Systems in the Northern Basin and Range Province," Geothermal Resources Council Special Report 13, pp. 95-119.

Mariner, R.H., C.A. Brook, M. J. Reed, J.D. Bliss, A.L. Rapport, and R.J. Lieb, 1983. Assessment of Low-Temperature Geothermal Resources of the United States-1982, U. S. Geological Survey Circular 892, $73 \mathrm{p}$.

Mase, C. W., and J. H. Sass, 1980. Heat Flow from the Western Arm of the Black Rock Desert, Nevada, U. S. Geological Survey Open-File Report, 80-1238, 38 p.

Monastero, F.C., C.A. Shepherd, S.C. Bjornstad and A.M. Katzenstein, 1989. "Potential and U.S. Navy Plans to Develop Geothermal Resources at Naval Air Station, Fallon, Nevada," Geothermal Resources Council Transactions, v. 13, pp. 179-186.

Muffler, L.J.P., ed., 1979. Assessment of Geothermal Resources of the United States--1978, U. S. Geological Survey Circular 790, 163 p.

Olmsted, F.H., P.A. Glancy, J.R. Harrill, F.E. Rush, and A.S. VanDenburgh, 1975. Preliminary Hydrogeologic Appraisal of Selected Hydrothermal Systems in Northern and Central Nevada, U.S. Geological Survey Open-File Report 75-56, 267 p.

Richards, Maria and David Blackwell, 2002, The Forgotten Ones: Geothermal Roads Less Traveled in Nevada, Geothermal Resources Bulletin, 31, no. 2, 69-75.

Sass, John, 2001b. "Great Basin Geothermal," Geothermal Resources Council Bulletin, v. 30, n. 5, pp. 195-197.

Sass, J.H., S.S. Priest, A.J. Blanton, P.C. Sackett, S.L. Welch, and M.A. Walters, 2001a. Geothermal Industry Temperature Profiles from the Great Basin. USGS-SASS99, U.S. Geological Survey Open-File Report 99-425, Online version 1.0, http://wrgis.wr.usgs.gov/open-file/of99425/webmaps/home.html.

Sass, J. H., J. P. Ziagos, H. A. Wollenberg, R. J. Munroe, D. E. di Somma, and A. H. Lachenbruch, 1977. Application of Heat Flow Techniques to Geothermal Energy Exploration, Leach Hot Springs Area, Grass Valley, Nevada, U. S. G S. Open-File Report, 77-762, 125 p. 
Sass, J.H., M.L. Zoback, and S.P. Galanis, 1979. Heat Flow in Relation to Hydrothermal Activity in the Southern Black Rock Desert, Nevada, U.S. Geological Survey Open File Report 79-1467, pp. 1-13.

Sorey, M.L., and F.H. Olmsted, 1994. "The Hydrothermal System Associated with Leach Hot Springs in Southern Grass Valley, Nevada," Geothermal Resources Council Transactions, v. 18, pp. 31-36.

Trexler, D.T., T. Flynn, B.A. Koenig, E.J. Bell, and G. Ghusn, 1982. Low to Moderate Temperature Geothermal Resource Assessment for Nevada: Area Specific Studies, Pumpernickel Valley, Carlin and Moana: Final Report, June 1, 1981 - July 31, 1982, U.S. Department of Energy, Report DOE/NV/10220-1 (DE82018598), 177 p.

Williams, B., and B. Helms, 1983. Final Report Grace Geothermal Corp., Baltazor Hot Springs, Nevada, Hole 45-14, SWDX JOB NO: 23-82, 9 p. 


\section{Section 3. Heat Loss - A Diagnostic Geothermal Resource Property}

\subsection{Introduction}

When the search for a new geothermal prospect begins, just about the whole exploration gamut geological, geochemical, and geophysical - takes place. Though naturally occurring heat loss is not routinely determined for exploration reports, it is a vital indicator of the geothermal system strength (Wisian et al., 2001). Heat loss is important because estimating the available production capacity at an early stage in the exploration has significant economic benefits.

In the previous chapter we described a number of parameters that can be used to compare aspects of collected data in the SMU Western Geothermal Data Base (Richards and Blackwell, 2002). This chapter will now focus on a single parameter - heat loss.

Down to a depth of about 10 meters below the Earth's surface, the air temperature seasonally influences ground temperature. Beyond this depth, the temperature of the Earth's interior is the only determining factor. Heat loss is the measurement of this thermal energy being transferred to the surface. (See the side box: "Heat Loss Basics.") Heat loss is relatively simple to calculate after a geothermal system has been defined by thermal gradient well drilling; multiple deep wells are not needed, Wisian et al. (2001).

\section{Heat Loss Basics}

As geothermal fluids rise to the surface, a transfer of heat from the fluid to the surrounding rocks takes place. So by the time a geothermal fluid reaches the Earth's surface it has usually cooled by some amount, perhaps even to the mean surface temperature of the area. The lost heat is transferred either to the ground conductively or to the air/surface convectively. When the fluid moves very slowly upward or even horizontally, the source heat is partially or completely transferred to the surrounding rock by conductive heat loss, lowering the fluid temperature. The conductive heat loss produces the thermal aureole that is mapped by thermal gradient drilling. If fluids rise quickly to the surface, before complete heat transfer can take place, then a hot spring, geyser, or fumerole results.

Two techniques of determining the heat loss of a system are:

1) Multiply the "system" or "reservoir" temperature x surface fluid flow rate, for known flow rate systems with accurate system temperatures.

2) Sum the total heat lost in the thermal aureole, for where spring reservoir temperatures are not known or not sampled and little or no surface discharge occurs.

Chemical geothermometers are used to estimate the geothermal system (deep or reservoir) temperature of the hot springs. However, fluids sampled at the surface (if any are available), are often not appropriate for determining the geothermal system source temperature with geothermometers because of shallow chemical changes in water chemistry.

A complete method of calculating heat loss needs to combine the conductive and convective components. To measure the conductive loss a contour map of the elevated heat flow- the amount above the regional background level- is integrated. Second, the convective thermal loss occurring from the area springs is determined (flow rate $\mathrm{x}$ surface temperature), relative to their maximum geochemical temperature and the flow rate. Sum the two parts together to estimate the area heat loss. Where possible, it is important to compare the complete method of heat loss estimation to technique 1 above. If there is lack of agreement, it is often due to an inaccurate "geothermal system" temperature from the geothermometer calculation since this has greater uncertainty.

Total surface heat loss is described as the sum of the convective and conductive components of the geothermal system. Fluid (convective) discharge can be a significant percentage of the total natural surface heat loss - at times over 50 percent - but in most cases is less than 20 percent of the 
total loss (Wisian et al., 2001). Thus, where possible, it is important to include the amount of surface fluid discharge in order to determine the total surface heat loss. Heat loss of specific hot springs has been previously estimated by Waring et al. (1965), Renner et al. (1975), and Garside and Shilling (1979) for some of the Great Basin geothermal systems. compared the surface heat loss to the existing electrical output of geothermal power plants around the world, demonstrating that surface heat loss can be used to broadly predict potential production capacity of geothermal systems (Figure 3.1).

\subsection{The How To's of Heat Loss}

To determine heat loss of an undeveloped system, with the goal of predicting production capacity, five main steps are involved. First, background heat flow must be determined. For the Basin and Range, the background heat flow is generally considered $80-90 \mathrm{~mW} / \mathrm{m}^{2}$ (Richards and Blackwell, 2002, Blackwell and Steele, 1992). Second, thermal conductivity is determined or estimated. This is collected from lithology or geophysical logs and porosity, or can be taken from published thermal conductivity estimates (Sass, 2001, Blackwell and Steele, 1989, Nathenson et al., 1983). Third, the temperature gradient information from the wells is multiplied by the conductivity to determine prospect heat flow. Fourth, the areal extent (square area) of the heat flow contours above the local background heat flow level is calculate to determine heat flow above that base. Fifth, all foregoing calculations are converted into watts using the equation: $\left(\mathrm{m}^{2} \cdot m \mathrm{~W} / \mathrm{m}^{2} \cdot{ }^{1 \text { Watt }} / 1000 \mathrm{~m}=\right.$ Watts $)$. The geothermal system heat loss (Watts) can be used to estimate the production capacity of the area being explored.

\subsection{Heat Loss of Nevada Prospects}

Nevada has 38 undeveloped geothermal prospects with adequate thermal gradient information to estimate the heat loss (Table 3.1). The sum of heat loss from these prospects is over 600 megawatts. The table shows both estimated heat loss (this is without the fluid/steam discharge component added) and the approximate area of the geothermal anomalies. Larger areas, such as Baltazor-McGee $\left(648 \mathrm{~km}^{2}\right)$ and North Valley -Trinity Mountain $\left(271 \mathrm{~km}^{2}\right)$, probably represent multiple geothermal systems without defined surface boundaries. Carson Sink and Southern Pacific geothermal areas, not in Table 3.1, are prospects where no heat loss was calculated because of their large spatial extent without defined thermal boundaries.

As shown in Table 3.1, there are large differences in the ratio between the amount of heat loss and the area from which heat is lost. Prospects Baltazor-McGee and McCoy have approximately the same estimated heat loss (47 megawatts), yet McCoy is less than half as large in areal extent as Baltazor-McGee. The spacing and number of wells impacts the ability to map thermal aureole limits, with respect to the background temperature, and therefore, heat flow contouring. Wells that are dispersed evenly over a prospect area, reflecting both the elevated thermal aureole and the background heat flow, offer the best possible scenarios. The Pirouette Mountain and Shoshone-Reese River prospects are examples of more defined areas. For their smaller area sizes, Pirouette Mountain (61 $\mathrm{km}^{2}$ ) and Shoshone-Reese River $\left(44 \mathrm{~km}^{2}\right)$ have above average heat loss of 19 megawatts. Other geothermal prospects, such as Buffalo Valley, Hawthorne, or Hot Springs Ranch, have too few measurements in a concentrated area to accurately estimate heat loss. The minimum number of wells used is five and the average density of wells is 0.5 wells $/ \mathrm{km}^{2}$. 


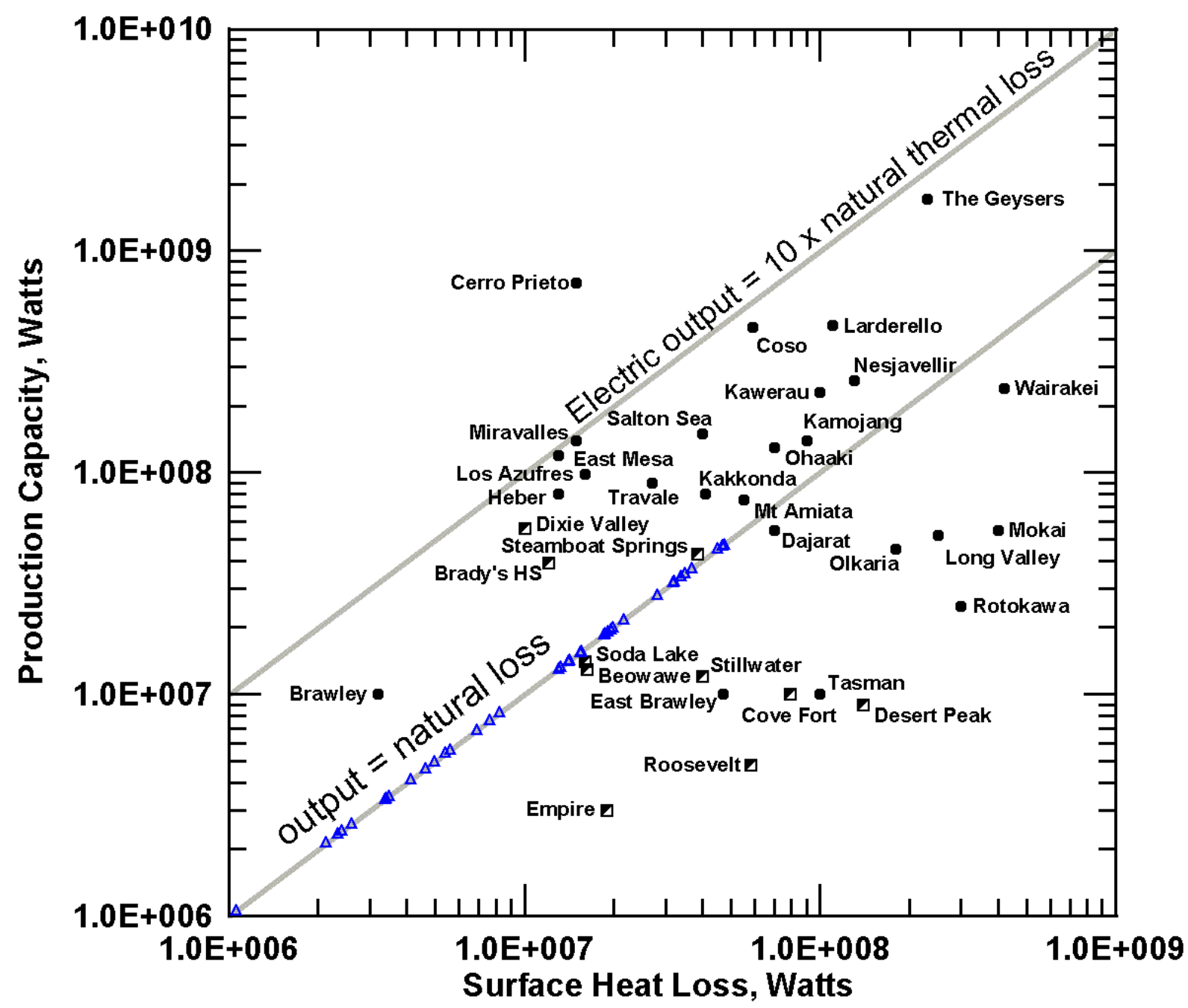

Figure 3.1. Production capacity of existing geothermal areas versus their surface heat loss (after Wisian, 2001). The square symbol is for geothermal plants in the Great Basin. The circles are for all other geothermal plants. The triangles represent the heat loss of undeveloped geothermal prospects in Nevada. (See Table 3.1 for prospect names and estimated heat loss.)

Natural fluid heat loss to the surface - springs and fumeroles - are not significant to our heatloss estimates (Garside and Schilling, 1979); and for consistency of heat loss comparisons it is not included. To determine the total surface heat loss this factor would be added for greater accuracy. Since this heat loss method is designed as a preliminary estimate of production capacity, for use during the beginning stages of exploration, it is not necessary to have the total surface heat loss. The estimated heat loss of these prospects in Table 3.1, are plotted in Figure 3.1 as triangles, shown as electrical production capacities related to their natural thermal system loss.

If considering both developed and undeveloped geothermal systems, the greatest heat loss estimate in Nevada is Desert Peak with a heat loss of 140 megawatts and a 9.9 megawatt power plant. Other areas in Nevada currently with geothermal power plants range in size from Dixie Valley with a power plant of 66 megawatts and a heat loss of 19 megawatts, to Empire with a power plant of 3.6 megawatts and a heat loss of 31 megawatts (including San Emidio). 
Table 3.1. Estimated Heat Loss in Nevada Geothermal Systems: prospects with reasonable geothermal potential as depicted by heat loss.

\begin{tabular}{|c|c|c|c|}
\hline PROSPECT AREAS & $\begin{array}{l}\text { Heat } \\
\text { Loss } \\
\text { MW }\end{array}$ & $\mathbf{K} \mathbf{M}^{2}$ & $\begin{array}{l}\text { No. of } \\
\text { Wells }\end{array}$ \\
\hline McCoy & 47 & 268 & 65 \\
\hline Baltazor - McGee & 47 & 648 & 44 \\
\hline Black Rock Desert & 45 & 435 & 48 \\
\hline Silver Peak & 37 & 152 & 17 \\
\hline Pumpernickel Valley & 35 & 226 & 17 \\
\hline Adobe Valley & 34 & 254 & 17 \\
\hline North Valley - Trinity Mtns. & 32 & 271 & 73 \\
\hline Fallon & 32 & 214 & 57 \\
\hline Kyle Hot Springs & 28 & 173 & 14 \\
\hline Dyke Hot Spring & 22 & 336 & 14 \\
\hline Gerlach & 20 & 60 & 36 \\
\hline Fly Ranch & 20 & 148 & 22 \\
\hline Pirouette Mtn. & 19 & 61 & 48 \\
\hline McFarlanes & 19 & 296 & 46 \\
\hline Shoshone - Reese Rv. & 19 & 44 & 52 \\
\hline Fireball Ridge & 16 & 149 & 10 \\
\hline Rye Patch -Humboldt House & 15 & 178 & 127 \\
\hline Fish Lake & 14 & 50 & 18 \\
\hline Wilson Hot Spring & 14 & 53 & 35 \\
\hline Tracy & 13 & 55 & 13 \\
\hline New York Canyon & 13 & 62 & 7 \\
\hline Colado & 8 & 41 & 24 \\
\hline Tuscarora & 8 & 96 & 40 \\
\hline Blue Mountain & 8 & 6 & 12 \\
\hline Leach Hot Springs & 7 & 128 & 116 \\
\hline Excelsior & 6 & 40 & 9 \\
\hline Deeth & 5 & 80 & 10 \\
\hline Dry Lake and Nightingale & 5 & 262 & 22 \\
\hline Alum & 5 & 20 & 12 \\
\hline Eleven Mile Canyon & 4 & 54 & 50 \\
\hline Aurora & 3 & 28 & 17 \\
\hline Ruby Valley & 3 & 20 & 14 \\
\hline Ralston & 3 & 62 & 8 \\
\hline Ely & 3 & 21 & 6 \\
\hline White Pine & 2 & 31 & 63 \\
\hline Temoak & 2 & 58 & 8 \\
\hline Delcer Buttes & 2 & 9 & 5 \\
\hline Big Smoky Valley & 1 & 9 & 6 \\
\hline
\end{tabular}


There are a total of ten geothermal power plants in Nevada operating at approximately 200 megawatts. Some are being run below their natural loss and thus are underdeveloped. If they were all run at the natural loss as determined by their heat loss, their capacity would be approximately 330 megawatts. On the other hand, Dixie Valley and Brady Hot Spring power plants are producing successfully at production rates greater than their apparent natural loss (Figure 3.1).

The limit for electrical production of a geothermal system is generally less than 10 times the natural thermal loss of the system. In planning for production of a geothermal system, a production rate at or lower than the natural thermal loss of the system allows for a longer production lifetime at a specific capacity. On the other hand, a geothermal system can produce at rates higher than its natural thermal loss for a shorter period of time, or develop a scenario where the heat is mined using water recharge into the geothermal system to extend the production life (Sorey et al.,1983). The Geysers in California is an example of a power plant run at elevated production rates in the late 1980's and had a drop in production. Today with reinjection and heat mining the output is just below the rate of 10 times the natural loss, (Sanyal, 2000).

\subsection{Conclusions}

Determining heat loss is one more tool to use in geothermal exploration. It is relatively easy to calculate if the thermal aureole has been mapped with thermal gradient well measurements. With the heat loss information, predicted production capacity can be used to help review the system being explored. In 2001 it was estimated by National Renewable Energy Laboratory that Nevada has the potential of 2,500 to 3,700 megawatts of electricity from untapped geothermal resources (NREL, 2001). From the heat loss determination of developed and undeveloped geothermal areas in Nevada, a very minimum potential production capacity of approximately 1,000 megawatts is readily available. With production planning and heat mining, this amount could positively increase.

In the SMU Western Geothermal Data Base, available on-line at: www.smu.edu/geothermal, there are 70 separate geothermal areas with elevated heat flows above $150 \mathrm{~m} \mathrm{~W} / \mathrm{m}^{2}$ in Nevada. Garside and Schilling (1979) determined 298 separate geothermal areas in Nevada as depicted by hot springs or hot wells. Therefore, it is highly probable that there are still many more geothermal systems yet to be discovered in Nevada and the Basin and Range Province in western United States.

\subsection{References}

Blackwell, D.D. and J.L. Steele, Geothermal Map of North America, Geol. Soc. Amer. DNAG Map No. 006, 1:5,000,000, 1992.

Blackwell, D.D. and J.L. Steele, Thermal Conductivity of Sedimentary Rocks: Measurement and Significance, 12-36, in N.D. Naeser and T.H. McCulloh, eds., Thermal History of Sedimentary Basins: Methods and Case Histories, Springer-Verlag, New York, 1989.

Bodvarsson, G., Geothermal Resource Energetics, Geothermics, 3, 83-92, 1974.

Brook, C.A., R.H. Mariner, D.R. Mabey, J.R. Swanson, Marianne Guffanti, and L.J.P. Muffler, Hydrothermal Convection Systems with Reservoir Temperatures $>90^{\circ} \mathrm{C}$, in L.P.J. Muffler, ed., Assessment of Geothermal Resources of the United States-1978, U. S. Geol. Surv. Circ. 790, 163 pp., 1979.

Garside, L.J. and J.H. Shilling, Thermal Waters of Nevada, Nevada Bureau of Mines and Geology Bull., 91, 163p., 1979.

Muffler, P. and R. Cataldi, Methods for Regional Assessment of Geothermal Resources, Geothermics, 7, 53-89, 1978.

Nathenson, M., M. Guffanti, John H. Sass, and Robert J. Munroe, Regional Heat Flow and 
Temperature Gradients, in M.J. Reed, ed., Assessment of Low-Temperature Geothermal Resources of the United States-1982, U. S. Geol. Surv. Circ. 892, 73 pp., 1983.

NREL, Geothermal Energy: Heat from the Earth, Nevada report, www.eren.doe.gov/geopoweringthewest/pdfs/nevada.pdf, 2 pp., 2001.

Renner, J.L., D.E. White, and D.L. Williams, Hydrothermal Convection Systems, in White, D.F. and D.L. Williams, eds., Assessment of Geothermal Resources of the United States-1975, USGS Circular 726, 5-57, 1975.

Richards, Maria and David Blackwell, The Forgotten Ones: Geothermal Roads Less Traveled in Nevada, Geothermal Resources Bulletin, 31, no. 2, 69-75, 2002.

Richards, Maria and David Blackwell, The Nevada Story- turning a loss into a gain, Geothermal Resources Bulletin, v. 31, no. 3, 107-110, 2002.

Sanyal, S. K., Forty Years of Production History at The Geysers Geothermal Field, California-The Lessons Learned, Geothermal Resources Council Trans., 24, 317-324, 2000.

Sass, J., Great Basin Geothermal, Geothermal Resources Council Bulletin, 30, 5, 195-197, 2001.

Sorey, M. L., M. Nathenson, and Christian Smith, Methods for Assessing Low-Temperature Geothermal Resources, in Reed, M.J., ed., Assessment of Low-Temperature Geothermal Resources of the United States-1982, U. S. Geol. Surv. Circ. 892, 73 pp., 1983.

Waring, G.A., R.R. Blankenship, and R. Bentall, Thermal Springs of the United States and Other Countries of the World-A Summary, USGS Professional Paper 492, 383, 1965.

White, D.E. and D.L. Williams, eds., Assessment of Geothermal Resources of the United States-1975: U.S. Geol. Surv. Circ. 726, 155 pp., 1975.

Wisian, K. W., D. D. Blackwell, and M. C. Richards, Correlation of Surface Heat Loss and Total Energy Production for Geothermal Systems, Geothermal Res. Council Trans., 25, 331-336, 2001. 


\section{Section 4. Regional Geophysics of Dixie Valley - Example of A Large Basin and Range Geothermal Resource}

\subsection{Introduction}

The Dixie Valley Producing Field (DVPF, see Figure 4.1) was developed between 1979 and 1988. During the last 14 years about $60 \mathrm{MW}$ of electrical power have been produced here, initially by Oxbow Power (since 2000 by Caithness). This geothermal system has been described by Benoit $(1992,1999)$. The field consists of two groups of production wells in sections 33 and 7, with injection wells in between (section 5) and to the south (section 18 and Lamb Ranch). The DVPF has the highest temperatures $\left(248^{\circ} \mathrm{C}\right)$ found in the province in a nonmagmatic producing geothermal system. There are numerous geothermal sites in Dixie Valley in addition to the production area. These include several hot springs - Sou, Seven Devils, Dixie Meadows, Lower Ranch and Hyder; three blind areasDixie Comstock Mine, Pirouette Mountain and Eleven Mile Canyon; along with other geothermal areas as shown in Figure 4.1. In the case of the blind areas, high temperatures were noted in an audit in the Dixie Comstock mine, and two others were located by random areal thermal gradient drilling in southern Dixie Valley- Pirouette Mountain and Eleven Mile Canyon, (Hunt, unpublished data, Western Geothermal Database, 2001). Another nearby blind system, McCoy, was located by temperature logging of an existing stock well (Olsen et al., 1979). There are two separate producing regions in the Dixie Valley Producing Field (DVPF) in sections 7 and 33 (see index map, Section 6, Figure 6.2) and a very hot region in the Dixie Valley Power Partners (DVPP) area immediately to the south where temperatures reach $285^{\circ} \mathrm{C}$ in well 36-14. Two areas of fumaroles (Senator and section 10 , $25 \mathrm{~N} / 37 \mathrm{E}$ ) are associated with the DVPF and DVPP areas. Drilling has confirmed temperatures of at least $198{ }^{\circ} \mathrm{C}$ at $2.5 \mathrm{~km}$ depth between the Dixie Comstock area to the south and the Senator fumaroles to the north. In spite of all of the evidence of thermal activity throughout the valley, deep wells have only been drilled near the producing field, and at the south end of the valley where Hunt drilled three deep wells in 1979/80.

The number and extent of the thermal anomalies in a setting of active Basin and Range faulting suggests that there are undiscovered resources there. Therefore, the Dixie Valley area is clearly a regional geothermal target. The objective of this chapter is to summarize the structural characteristics of the greater Dixie Valley area as an indication of locations and settings that might be favorable for additional exploration of the geothermal potential of this large area.

\subsection{Geophysical Data}

Seismic Data Seismic reflection data are available for the area of the producing geothermal field and the area to the north. These data are discussed in Section 6 of this report along with the detailed gravity and magnetic studies, and the drilling results. Widely spaced refraction data were described by Thompson et al. (1967).

Thermal Gradient Drilling A large number of wells, to a variety of depths, were drilled in the exploration phase in the late 1970's and early 1980's. Thermal data for many of the wells (223, of which 96 have depth information) are included in the Western Geothermal Database (WGD) (Richards and Blackwell, 2002). There are 53 wells in the depth range of less than $150 \mathrm{~m}$ and 31 wells in the depth range of 150 to $650 \mathrm{~m}$ in the WGD. There are 7 deep wells, more than $2000 \mathrm{~m}$, outside of the 


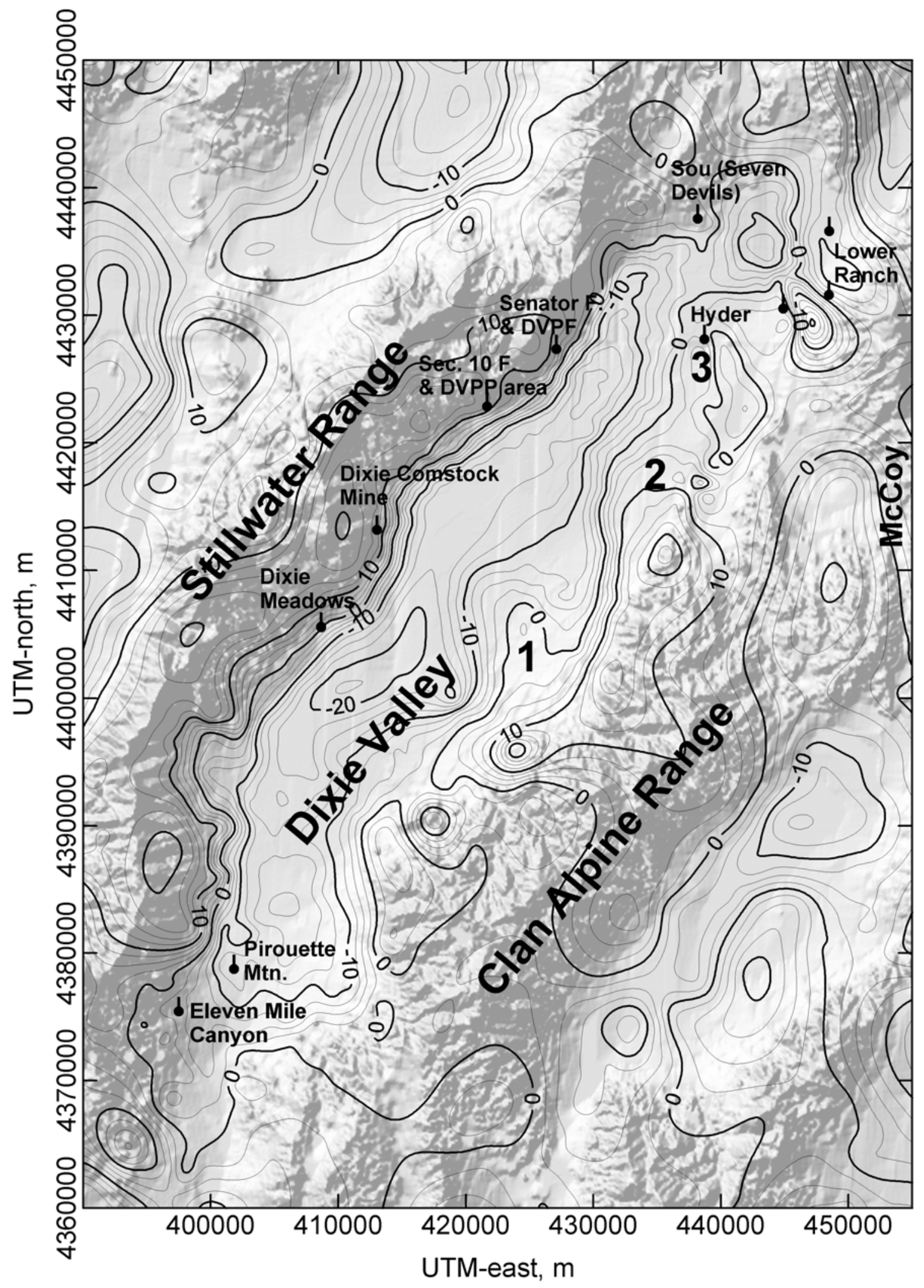

Figure 4.1. Residual Bouguer gravity anomaly map of the Dixie Valley area. Geothermal sites mentioned in the text are located and named. 
Dixie Valley Producing Field and the Dixie Valley Power Partners areas (Blackwell et al., 2000). Four of the wells are in the northern part of the valley. One is located to the north, one to the east, and two to the south (one of them near the Dixie Comstock mine, 45-14). Three deep wells were drilled at the extreme southern end of the valley in the Pirouette Mountain and Eleven Mile Canyon areas. At least some results are available for all of these wells except the southern most pair.

Gravity Data Gravity is important because it proved key in understanding the nature of the fault system in the producing field (Blackwell et al., 1999) and these studies may give information on the possible reservoir structure in other parts of the valley. There have been many gravity studies carried out in the Dixie Valley area. These included widely spaced regional measurements and a study carried out in the southern part of the valley for Hunt Oil in the late 1970's (unpublished report, 1979). Detailed local studies were carried out in the vicinity of the producing field for Sun Oil and Southland Royalty (AMOCO, unpublished, 1979; TransPacific, unpublished, 1979). In 1996, we carried out a detailed study along the range front in the vicinity of the DVPF and the DVPP areas (Blackwell et al., 1999). In 2000, we carried out a study to fill in along the range front between the 1996 studies and the Hunt survey to the south. These data have all been combined and are shown in Figure 4.1 and described for the first time at the 2002 Geothermal Resources Council Meeting in Reno. A residual Bouguer anomaly map is shown. The residual was calculated by removing a smoothed average gravity value from the regional complete Bouguer gravity anomaly values.

Dixie Valley shows clearly as a region of negative residual gravity (generally about -15 mgal in the lowest areas) due to the low density of the valley fill with respect to the bedrock ranges. The valley essentially terminates near the northern and southern ends of the figure. The gravity in the Stillwater Range is about +15 mgal while in the Clan Alpine Range the residual gravity values range from over +10 to about 0 mgal. The gravity relief is less in the southern half of Dixie Valley, particularly with respect to the areas to the south and east. The Clan Alpine Range has Cenozoic volcanics exposed over most of the surface area and so there is less of a density contrast with the sediments in Dixie Valley. At both the southern and northern ends of the valley there are abrupt changes in the strike of the gravity gradients between the valley and the bedrock. At the north end this change in strike is associated with a change in strike of the mapped young faults (Smith et al., 2002).

Magnetic Data A very early aeromagnetic survey of the area was described by Smith (1968). Aeromagnetic surveys were also a part of the exploration activities of the late 1970's and early 1980's (AMOCO, unpublished, 1979; Senturian, unpublished, 1979). More recently in early 2002 a high resolution low altitude aeromagnetic study was carried out based on success in imaging shallow expressions of intrabasin faults in the Albuquerque Basin (Grauch et al., 2001). That survey is described by Smith et al. (2002).

\subsection{Discussion}

The location of the major faults along the boundary between Dixie Valley and the Stillwater Range are of particular interest. At a broad scale the steepness of the gravity contours will outline the regions of greatest density contrast. A way of focusing on the locations of valley bounding faults is to calculate a slope map of the residual gravity anomaly. The steepness of the slope is related to the relief and the geometry of the range/valley contact. The locations of the maximum gravity slope values are shown as a line in Figure 4.2. The heavy line indicates a very steep gradient while the medium thickness line indicates a shallower, but significant, slope. In addition the range front fault is shown as the dashed line north of Dixie Meadows hot springs and as the location of the 1954 break south of Dixie Meadows. 


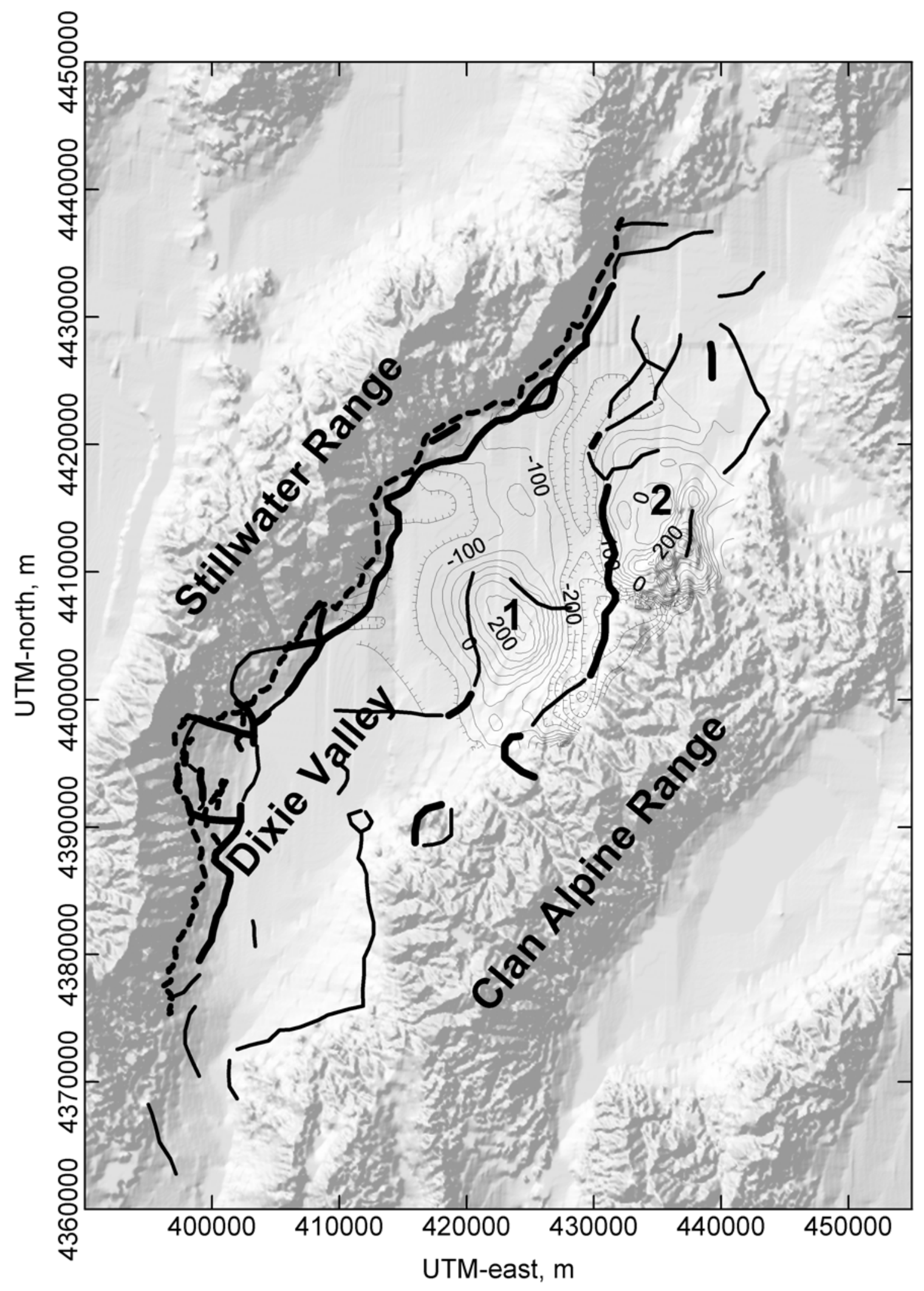

Figure 4.2. Comparison of the total field magnetic anomaly values to the positions of the steepest gradients of the residual gravity anomaly (see Figure 4.1). 
Also shown on Figure 4.2 are contours of the magnetic field from the Senturian Survey of 1978 by the thinnest lines. There is a close correlation of the steep gravity gradients within the valley on the east side and the presence of high magnetic field gradients around roughly circular positive total field magnetic field anomalies. In particular, the anomalies marked (1) and (2) on the magnetic map in Figure 4.2 and the relative positive gravity areas in the valley also marked (1) and (2) on Figure 4.1 are coincident. The southern area of positive magnetic field values was associated with subcrops of the Jurassic Humboldt lopolith based on an early magnetic survey described by Smith (1968). The anomaly marked (2) is associated with the outcrop of the lopolith in the Clan Alpine Range (Speed, 1976). The area of positive gravity at the northeastern end of Dixie Valley marked (3) on Figure 4.2 is also characterized by a positive magnetic feature (Smith et al., 2002) and lopolith rocks have been encountered at shallow depths beneath valley fill in intermediate depth thermal gradient wells. Thus the two relatively circular areas in Dixie Valley, where the gradients of the gravity field follow the contours of the magnetic field, are clearly related to lopolith bodies that are mostly buried. Clearly the mafic rocks of the lopolith are both dense and magnetic. Weaker positive magnetic anomalies, not so clearly related to gravity, are located along the western side of the valley and high magnetic field values are seen in the Stillwater Range at the edge of the various surveys.

The zone of active normal faulting along the west side of the valley is generally contained between the range front, where most of the topographic offset has occurred, and the steepest gravity gradient, where most of the valley offset has occurred. As shown in Figure 4.2, these two lines are generally 1 to $2 \mathrm{~km}$ apart so that there is generally a wide, shallow, basement block between the main piedmont fault and the range bounding fault. The mapping from aerial photos shows that the piedmont faults are located in places marked at the surface by subtle scarps and by graben structures, considerably removed from the range front, and in general coinciding with the positions of the steepest gravity gradients.

The faults mapped on the basis of aerial photos and from the aeromagnetic survey are discussed by Smith et al. (2002). The mapping shows an active west side to the valley where the displacement is on the order of $4 \mathrm{~km}$ and some minor distributed faulting in the area between the geographic center of the valley and the eastern side. The pattern of distributed faulting along the east side of the valley is particularly clear from the magnetic data. The net offset, however, based on the gravity data is only a fraction of that along the west side of the valley. The seismic data suggest that the valley started out as a narrow symmetrical graben and then later broadened toward a tilted fault block configuration with the major displacement along the west side of the valley. The gravity and geologic mapping suggest that the geometry of faulting all along the range valley contact is the same as that seen in the DVPF and the DVPP area. The general existence of a fault zone 1 to $2 \mathrm{~km}$ wide is well documented. This means that there is a large area of fractured rock for geothermal fluid flow. The recognition that rocks of the Humboldt lopolith underlie a large part of the valley is important from the geothermal resource point of view. The locations where the rocks of the lopolith are along the major normal faults are considered the best reservoir situations for Dixie Valley (Waibel, 1987). If the faulting is like that in the north, the individual faults are steep and will be much more easily located by drilling inclined wells rather than vertical wells.

\subsection{References}

Benoit, D., A review of various conceptual models of the Dixie Valley, Nevada, geothermal field, Geothermal Resources Council Trans., 23, 505-511, 1999.

Benoit, D., A case history of injection through 1991 at Dixie Valley, Nevada, Geothermal Resources 
Council Trans., 16, 611-620, 1992.

Blackwell, David D., Mark Leidig, and Richard P. Smith, Regional Geophysics of the Dixie Valley Area: Example of a Large Basin and Range Geothermal Resource, Geothermal Resources Council Trans., 26, 519-522, 2002.

Blackwell, D.D., Golan, B., and Benoit, D., Thermal regime in the Dixie Valley geothermal system, Geothermal Resources Council Trans., 24, 223-228, 2000.

Blackwell, D.D., Wisian, K.W., Benoit, D., and Golan, B., Structure of the Dixie Valley geothermal system, a "Typical" Basin and Range geothermal system, from thermal and gravity data, Geothermal Resources Council Trans., 23, 525-531, 1999.

Blackwell, D.D., Leidig, M., Smith, R.P., Johnson, S., and Wisian, K.W., Exploration and development techniques for Basin and Range geothermal systems: Examples from Dixie Valley, Nevada, Geothermal Resources Council Trans., 26, 513-518, 2002.

Grauch, V.J.S., Hudson, M.R., Minor, S.A., Aeromagnetic expression of faults that offset basin fill, Albuquerque Basin, New Mexico, Geophysics, 66, 707-720, 2001.

Hunt, Unpublished exploration data, Southern Methodist University Geothermal Lab. Western Geothermal Data Base, www.smu.edu/geothermal, 2001.

Olsen, H.J., Dellechaie, F., Pilkington, H.D., and Lange, A.L., The McCoy geothermal prospect, status report of a possible new discovery in Churchill and Lander Counties, Nevada, Geothermal Resources Council Trans., 3, 515-518, 1979.

Richards, Maria., and Blackwell, David, The Forgotten Ones: Geothermal roads less traveled in Nevada, Geothermal Bulletin, 31, 2, 69-75, 2002.

Smith, R.P., Grauch, V.J.S., and Blackwell, D.D., Preliminary results of a high-resolution aeromagnetic survey to identify buried faults at Dixie Valley, Nevada, Geothermal Resources Council Trans., 26, submitted, 2002.

Smith, R. P., Wisian, K.W., and Blackwell, D.D., Geologic and Geophysical evidence for intra-basin and footwall faulting at Dixie Valley, Nevada, Geothermal Resources Council Trans., 25, 323326, 2001.

Smith, T.E., Aeromagnetic measurements in Dixie Valley, Nevada: Implications on Basin-Range structure, J. Geophys. Res., 73, 1321-1331, 1968.

Speed, R., Geology of the Humboldt lopolith \& vicinity, Geol. Soc. Amer. Map MC-14, Boulder, Colo., 1976.

Thompson, G.A., Meister, L.J., Herring, A.T., Smith, T.E., Burke, D.B., Kovach, R.L., Burford, R.O., Salehi, I.A., and Wood, M.D., Geophysical study of Basin-Range structure, Dixie Valley region, Nevada, Air Force Cambridge Research Laboratory, Report No. 66-848, 1967.

Waibel, A., An overview of the geology and secondary mineralogy of the high temperature geothermal system in Dixie Valley, Nevada, Geothermal Resources Council Trans., 11, 479-486, 1987. 


\section{Section 5. Shallow Characteristics of Geothermal Systems - Why Basin and Range Systems are Hard to Find}

\subsection{Introduction}

If the potential of geothermal systems in the Basin and Range is so high, why have so few systems been developed? The objective of finding and developing the largest, hot targets during the 1970's and early 1980's exploration often limited interest in Basin and Range systems. Furthermore, the large number of geothermal systems in the Basin and Range meant certain criteria limited the exploration targets. As a consequence, only those systems that were large and had very good evidence of high temperatures were of drilling interest at that time.

The Basin and Range is an extensional system characterized by block faults. The complex faulting pattern provides the hot source fluids a pathway to reach the surface but also contributes to creating complicated shallow geothermal anomalies (Figure 5.1). Fumeroles will form above a range front fault where the upflow reaches boiling or higher temperatures below the surface. More often the upflow enters the groundwater, flowing laterally in porous valley fill that covers the fault(s). This situation affects the location of the surface manifestations of the geothermal anomaly.

Where upflow occurs along a fault, the conductive transfer of heat generates a deep thermal aureole around the flow path, as well as the shallow convective aureole near the surface. In a simplistic model, the deep thermal aureole would be parallel with the fault, extending away from the fault an amount dependant on the duration of fluid flow and the thermal conductance of the surrounding rocks. The heated fluids discharging laterally, as shown in Figure 5.1, create the shallow aureole. Both aureoles will change in shape and size over time as the heat is transferred further from the source. Over a long period of time the deep and shallow zones tend to converge into one thermal aureole. By determining the shape and size of the deep and shallow thermal aureoles during drilling, the possibility of successfully drilling into the actual upflow along the fault(s) is increased. Temperature measurements can be a powerful tool and reduce expenses if used appropriately throughout the exploration and production drilling phases. But understanding the unusual characteristics of shallow Basin and Range geothermal anomalies is necessary to properly utilize the well temperature measurements.

\subsection{Below the Surface Manifestations}

The arid climate and the surface drainage pattern of the Basin and Range are complicating factors to surface manifestation development (or lack of) around the deep geothermal system. In this region the majority of the discharge from the rivers and streams stays in the basin, either evaporating or recharging the groundwater. Since shallow groundwater is recharged from the surface drainage, it is cooler than the rising geothermal fluid and the two are tempered as they flow together through the water table (Figure 5.1). Due to the high relief, the edges of the valley are often many meters above the water table. The water table only reaches near the surface in the middle of the valleys. Thus, there are often minimal signs of elevated temperatures, such as, hot springs and chemical deposits, visible at the surface along the faults. Even where the water table does reach the ground surface, the warm/hot springs are often offset from the original fault source. Seldom are the shallow waters either unboiled or unmixed making it difficult to use the geochemical temperature for determining the maximum 


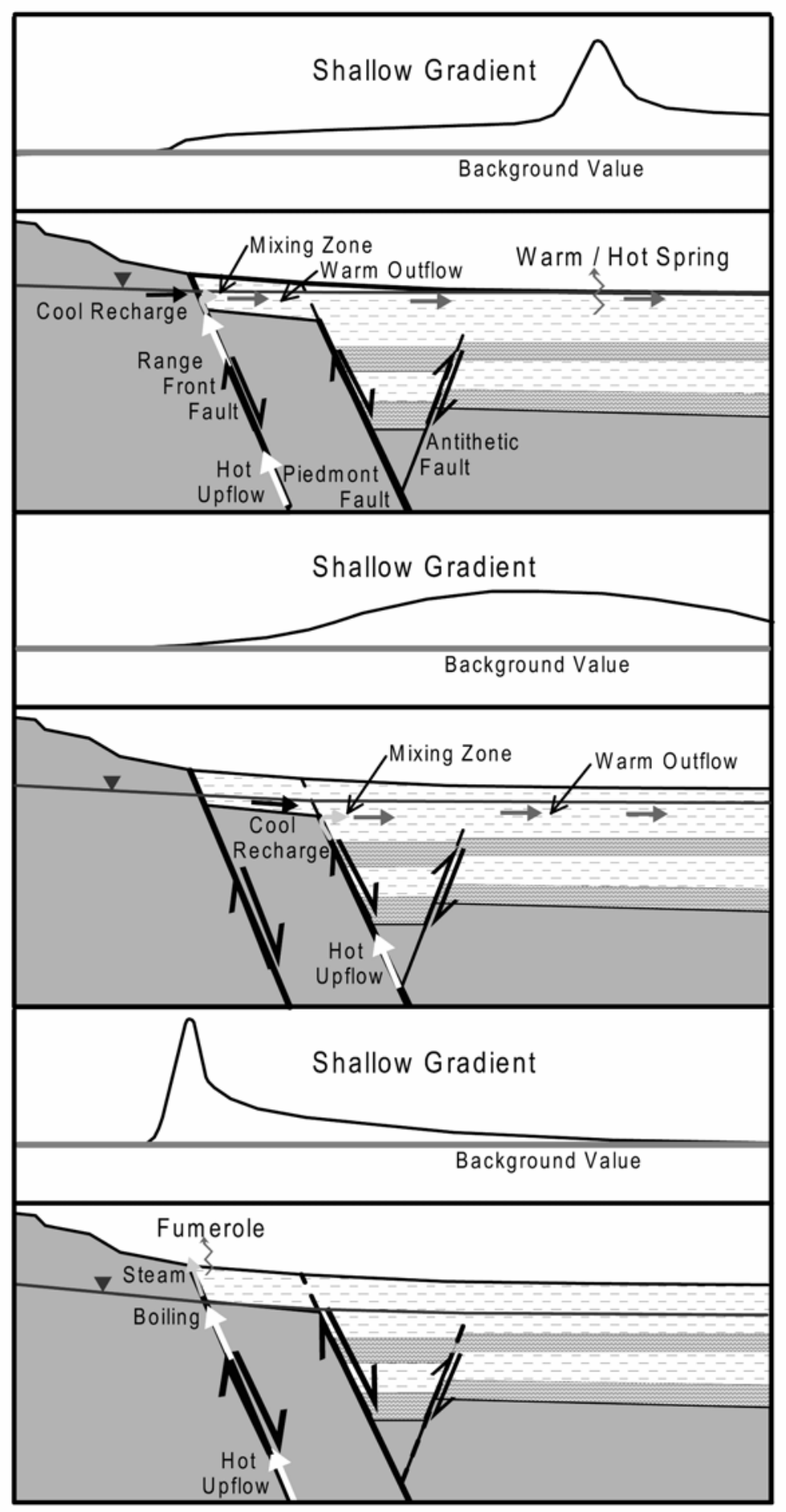

Figure 5.1. Three scenarios of shallow geothermal fluid movement in the Basin and Range. The hot fluids flowing along the faults interact differently with the water table creating varied surface effects. The upper curve for each scenario represents the gradient measured in shallow (100 m, $300 \mathrm{ft}$ ) exploration wells. 
reservoir temperature of the geothermal source. These typical features of the Basin and Range geothermal systems limit the surface manifestations of the system and complicate the use of surface or shallow measurements to properly estimate the source reservoir temperature and location.

During the initial exploration of a geothermal area a series of shallow wells $(90-150 \mathrm{~m})$ are usually drilled. The temperature-depth curves of these wells are used to determine where the deeper drilling will occur. In examining the well temperature profiles, there are many different scenarios. In the Basin and Range, the temperature-depth curves tend to be controlled by three patterns: the background, the shallow thermal aureole from heated lateral flow, and the deep thermal aureole (at the source of upflow) (Figure 5.2). The background curve (Figure 5.2, Background) has a gradient representative of the surrounding lithology and regional heat flow, generally higher thermal gradients in the valley fill, and lower linear gradients in the basement. The typical surface thermal aureole (Figure 5.2, 29-1) is characterized by a curve quickly increasing to very high temperatures in the permeable zone, then a reversal to cooler temperatures, and after that warming to a gradient near the background. This pattern is referred to as a roll-over or overturned temperature-depth curve. The curve representative of the deep thermal aureole (Figure 5.2, B21-1) has an initially high gradient with temperatures quickly rising and then leveling off, staying at the elevated temperature or slowly continuing to increase to the bottom of the borehole.

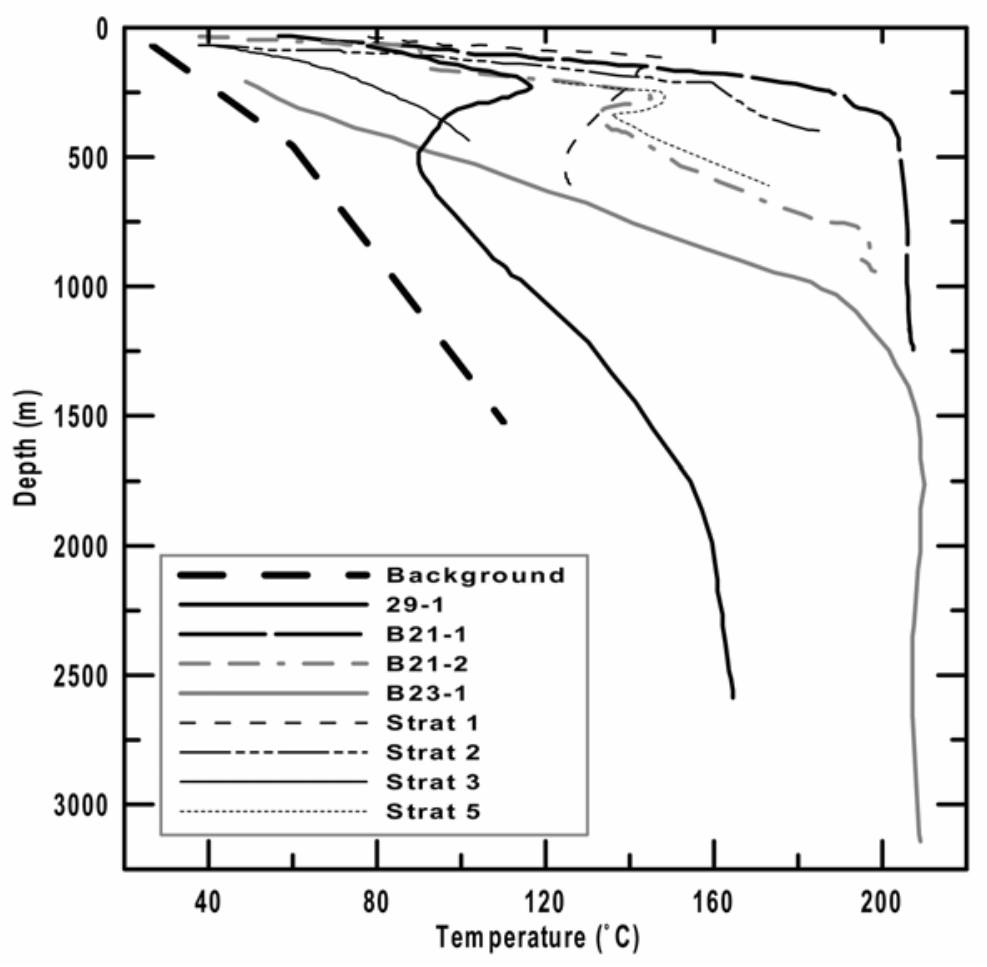

Figure 5.2. Selected temperature-depth curves from Desert Peak, Nevada with a generalized background temperature-depth curve. See Figure 5.3 for well locations.

Exploring for geothermal fluids in the Basin and Range is complex, but following a three-step process, using temperature-depth curves to assist in finding the upflow source along a fault, is helpful. 
First, drill multiple shallow wells to determine the area of elevated groundwater temperature. The shallow wells do not necessarily represent the location of the upflow source, rather signify that one does exist. Second, drill the next set of wells through the zone of elevated temperatures (shallow aureole) and the temperature reversal, stopping where the temperature returns to background level. These wells help differentiate the shape and location of the surface and deep thermal aureoles. Third, drill a test production well(s) into the area closest to the upflow source.

Every geothermal system will have its own signature temperature curves. Factors that can change the shape of the temperature curve are: the age of vertical and lateral flow, the amount of fluid movement, the source temperature, the lithology, the number of faults and the characteristics of groundwater flow.

\subsection{Thermal Exploration of Desert Peak}

An excellent case history of Basin and Range exploration has been described by Benoit et al. (1982) for the Desert Peak geothermal system. Although Desert Peak is an architypical extensional system in some respects, in others it is quite different. The main difference is that there is no obvious major structure to focus exploration. The surface is covered by young volcanics and sedimentary deposits.

Currently, Desert Peak has a power plant operating at 9.9 megawatts. The heat loss from this area is substantial and suggests that the system is underdeveloped, as is the case in most of the Basin and Range power plants (Richards and Blackwell, 2002b). There have been no new contracts for power sales to stimulate additional drilling in Desert Peak. The first drilling phase began with 53 shallow wells (nominally a depth of 91.5 meters) that delineated a large, intense thermal anomaly (Benoit et al., 1982) (Figure 5.3).

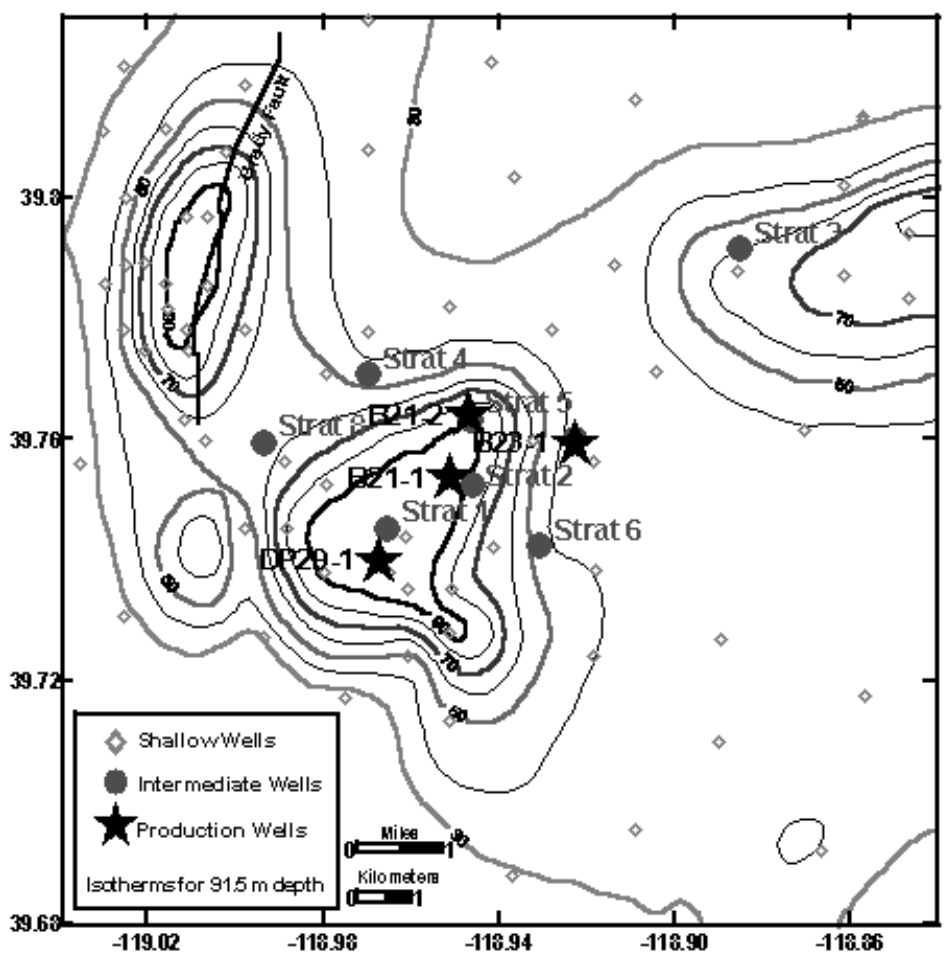

Figure 5.3. The well locations for Desert Peak, Nevada. Shown are $91.5 \mathrm{~m}$ depth temperature contours in the shallow temperature gradient wells. Temperature, in this case, is substituted for gradients, similar to the middle profile in Figure 5.1

Using the temperature curves and a few thermal conductivity measurements, the shallow temperature gradient and heat flow anomalies were mapped. From these data it was expected that 
drilling anywhere in the vicinity of the elevated temperature gradients found by the shallow wells would lead to a successful geothermal test well. Thus the site for geothermal test well 29-1 was selected based on the ease of location, within the middle of the thermal high. Well 29-1 was "dry" and cooler at the bottom than expected, but informative in giving more detailed temperature and lithology information (Figure 5.2). The reversal in temperature at 213 meters was a surprise, but illustrated that the shallow BHT found in the initial 53 wells outlined the shallow leakage from the deep thermal anomaly, not the deep geothermal reservoir.

To look below the masking effects of the shallow aquifer, eight intermediate $(<610$ meters $)$ wells were drilled (Strat- 1-8) (Figure 5.3) to construct the shallow thermal aureole and delineate the deep thermal aureole. The Strat wells were very successful in evaluating the extent of the deeper thermal aureole. Thus the second geothermal test well (B21-1) was successfully drilled near Strat-2, reaching $208^{\circ} \mathrm{C}$ at 1265 meters with enough fluid volume and pressure to make it productive. Immediately after, well B21-2 was drilled as a second production well, near Strat-5. This geothermal well is 973 meters deep with temperatures measuring $200^{\circ} \mathrm{C}$. Production flow tests show B21-1 and B21-2 to be in the same reservoir (Benoit, et al., 1982) (Figures 5.2 \& 5.3). Two years later B23-1 was drilled near Strat 7, but was never put into production because of problems with the well caving in.

In reviewing the temperature-depth curves of the Desert Peak wells, the lateral flow near the surface from the upflow along the fault, is easily distinguishable by the intermediate and deep wells (Figure 5.2). The shallow wells depicted where the surface groundwater was being heated, but were not able to define the conductive thermal aureole related to the upflow (Figure 5.3). Strat 3 to the northeast is on the very edge of the shallow thermal aureole with slightly elevated surface temperatures, but not drilled close enough to the flow zone to have developed a shallow overturn. On the opposite side of the valley, the curves of wells 29-1 and Strat 1, both have a high gradient that reverses, and then increases again with depth. The sharpness of the reversal and the gradient of the second increase are identifiers of where the wells are situated within the thermal aureole. Strat 1 is closer to the source of the thermal aureole. When comparing Strat 1 and Strat 2 wells, Strat 2 has only a slight change in gradient and higher temperatures where the heated lateral flow temperatures are measured, signifying it is nearer to the upflow source. Geothermal test wells B21-1 and B23-1 seem to be drilled into the upflow source. This is represented on the temperature curve by rapidly increasing temperatures which remain fairly constant as the well is drilled deeper.

\subsection{Beyond Desert Peak, Nevada}

Desert Peak is not an unusual case. Other examples of temperature curves for Basin and Range geothermal areas with shallow thermal aureoles are shown in Figure 5.4. The data for these curves are from the USGS website of Geothermal Industry Temperature Profiles from the Great Basin (Sass et al., 1999). Each area has two example temperature-depth curves. One curve represents a well drilled along the outer edge or through the shallow thermal aureole (shown as a solid line), and the second curve (a dashed line) is representative of drilling closer to the source fault.

The Reese River temperature curve (a) is only slightly above background by 55 meters and most likely the farthest from the source of these examples. The Reese River curve (b) is still a distance from the source fault. The upflow may have existed for a long time causing the shallow and deep thermal aureoles to converge and spread further out raising the geothermal system background 


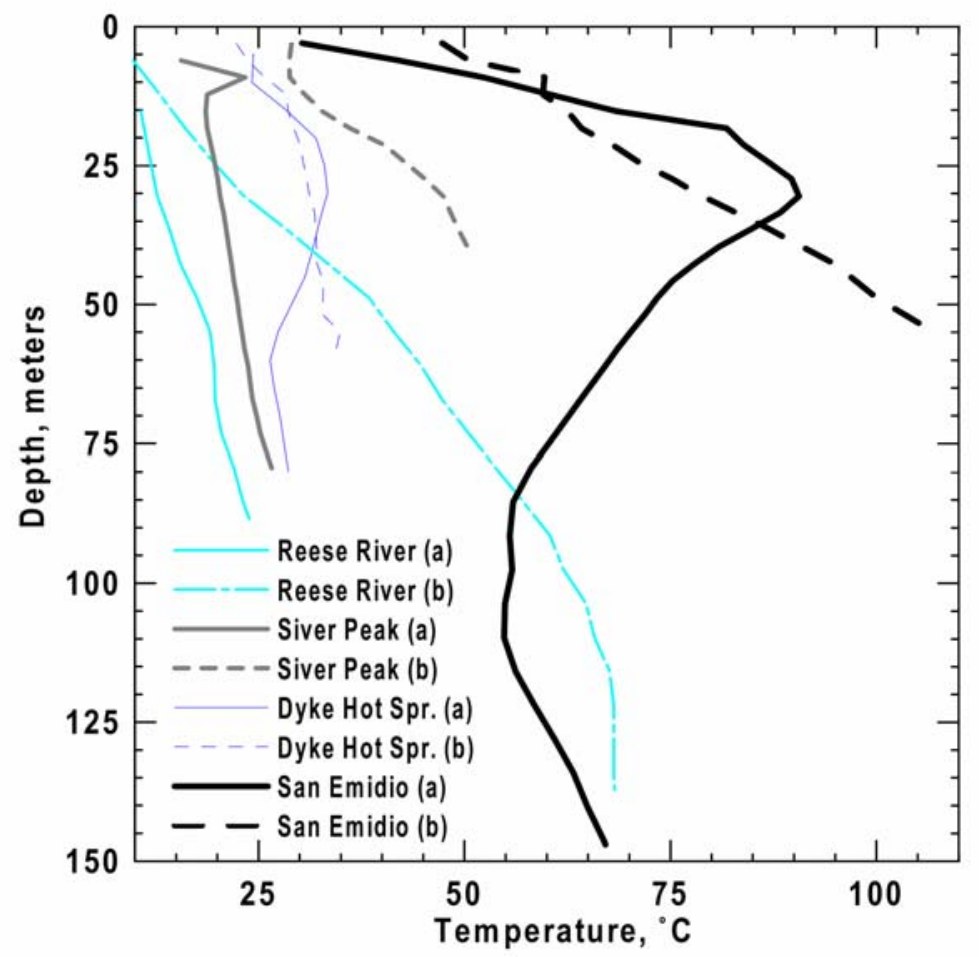

Figure 5.4. Examples of Basin and Range well temperature-depth curves. The solid lines represent wells drilled in or through a shallow thermal aureole. The dashed lines represent wells closer to the source of the hot fluid upflow source

temperature and thus reducing the reversal in a well. Silver Peak (a) has an unusually sharp peak at 10 meters. The 10 meter spike, if related to a thermal aureole affect, would represent a very recent hot fluid source. The Silver Peak (b) curve is increasing more rapidly in temperature, but needs to be drilled deeper (generally 150 - 300 meters) to determine the extent of (or if there is) an overturn there. This area is close to the California border halfway between Reno and Las Vegas, so the likelihood of recent earthquakes creating new flow paths is high. Dyke Hot Springs has a defined overturn, but the well still has not returned to the natural increase of its background temperature in line (a). Dyke Hot Springs (b) is only slightly higher in temperature than (a) and needs to be drilled deeper to fully determine if it is closer or further from the fault source. The two San Emidio temperature curves are examples of what geothermal exploration would like to find. The pattern of a rapid increase, then a relatively sharp overturn, after that a return to the background temperature easily defines the shallow thermal aureole. The San Emidio (b) curve is closer to the source of upflow as it is hotter than (a) and still has not yet reached the point of overturning.

\subsection{Conclusions}

If Desert Peak was drilled over again with today's knowledge, it would obviously be done differently. The initial geothermal test well (29-1) would have been drilled after the Strat wells were drilled and the shallow and deep thermal aureoles defined. Through better understanding of how to read temperature-depth curves, the decrease in temperatures of well 29-1 would cause concern at 900 meters, and by 2000 meters the drilling would most likely be stopped, as temperatures leveled off and it was realized that the well was too far from the upflow source. Well B23-1 would not be drilled to 
3000 meters expecting to reach substantially higher temperatures. Shallow gradients that seem too good to be true, are.

Temperature-depth curves can have a variety of wiggles and bends to them. They come in all shapes and sizes as seen by the few examples in this article. Drill holes can effect the movement of fluids and gases both in a well and along the casing, also changing the shape of the curve. This intra bore-hole flow adds an additional complication to interpreting what is happening below the ground surface. Understanding why the curves vary from the background temperature is an important aspect of geothermal exploration, especially in the Basin and Range. Yet, finding the resources to learn how to interpret temperature-depth curves is difficult. A tutorial of temperature-depth curves as well (as related articles) has recently been put on the www.smu.edu/geothermal website.

One outcome of technology improvements is the use of directional drilling for geothermal exploration. By measuring the well BHT as the well is drilled the drill can be steered to follow the increasing temperatures to reach the upflow source once a thermal aureole has been delineated properly. The goal though is to use the knowledge gained by the 1970's and 1980's exploration to reduce the amount of drilling and hit the geothermal target - upflow source as close to the surface as possible. With today's technology improving the ease of temperature readings and the enhanced understanding of what is occurring below the ground surface, there is little reason not to use the temperature measurement tool for assisting in the exploration of geothermal systems.

\subsection{References}

Benoit, D., J. E. Hiner, and R. T. Forest, Discovery and geology of the Desert Peak geothermal field: A case history, Nevada Bur. Mines Geol. Bull., 97, 82 pp., 1982.

Richards, Maria and David Blackwell, The Forgotten Ones: Geothermal roads less traveled in Nevada, Geothermal Resources Bulletin, v. 31, no. 2, 69-75, 2002a.

Richards, Maria and David Blackwell, The Nevada Story- turning a loss into a gain, Geothermal Resources Bulletin, v. 31, no. 3, 107-110, 2002b.

Richards, Maria and David Blackwell, A Difficult Search, Why Basin and Range systems are hard to find, Geothermal Bulletin, v. 31, no. 4, 143-146, 2002c.

Sass, John, Susan S. Priest, Arnold J. Blanton, Penelope C. Sackett, Stephanie L. Welch and Mark A. Walters, Geothermal Industry Temperature Profiles from the Great Basin, USGS Open-file Report 99-425 online version 1.0, http://wrgis.wr.usgs.gov/open-file/of99425/webmaps/home.html, 1999. 


\section{Section 6. Exploration Development Techniques For Basin and Range Geothermal Systems}

\subsection{Introduction}

As a result of recent drilling, the Dixie Valley geothermal system is now interpreted to be associated with a normal fault zone consisting of several steeply dipping major strands instead of a single master fault with splays (Benoit, 1999; Blackwell et al., 1999, 2000). A cross section is shown in Figure 6.1. We have revisited the available exploration data in the light of this new understanding. The objective of this chapter is to summarize the exploration data in order to see what techniques work the best and should be used in the exploration for, and evaluation of, Basin and Range geothermal systems of the Dixie Valley type. This chapter will focus on gravity and seismic data in conjunction with the drilling results. New aeromagnetic data are described by Smith et al. (2002).

An index map to the geothermal field is shown in Figure 6.2 and the line of the structure section in Figure 6.1 is shown. Drilling has shown that the range front fault is not responsible for the valley displacement. There is at least a second major fault zone (referred to as a piedmont fault), typically about 1-2 km away from the range front, that often carries most of the valley displacement. All of the current production in Dixie Valley comes from wells drilled into the piedmont fault zone and none of the current production or injection wells penetrate the range-bounding fault. The implications of this new model are that a large zone rather than a single fault forms the reservoir, that there is open porosity even in parts of the fault system that are not directly connected to the surface, and that the faults are very steep (on the order of $75^{\circ}+$ ). Thus directional drilling is the best way to explore in the systems.

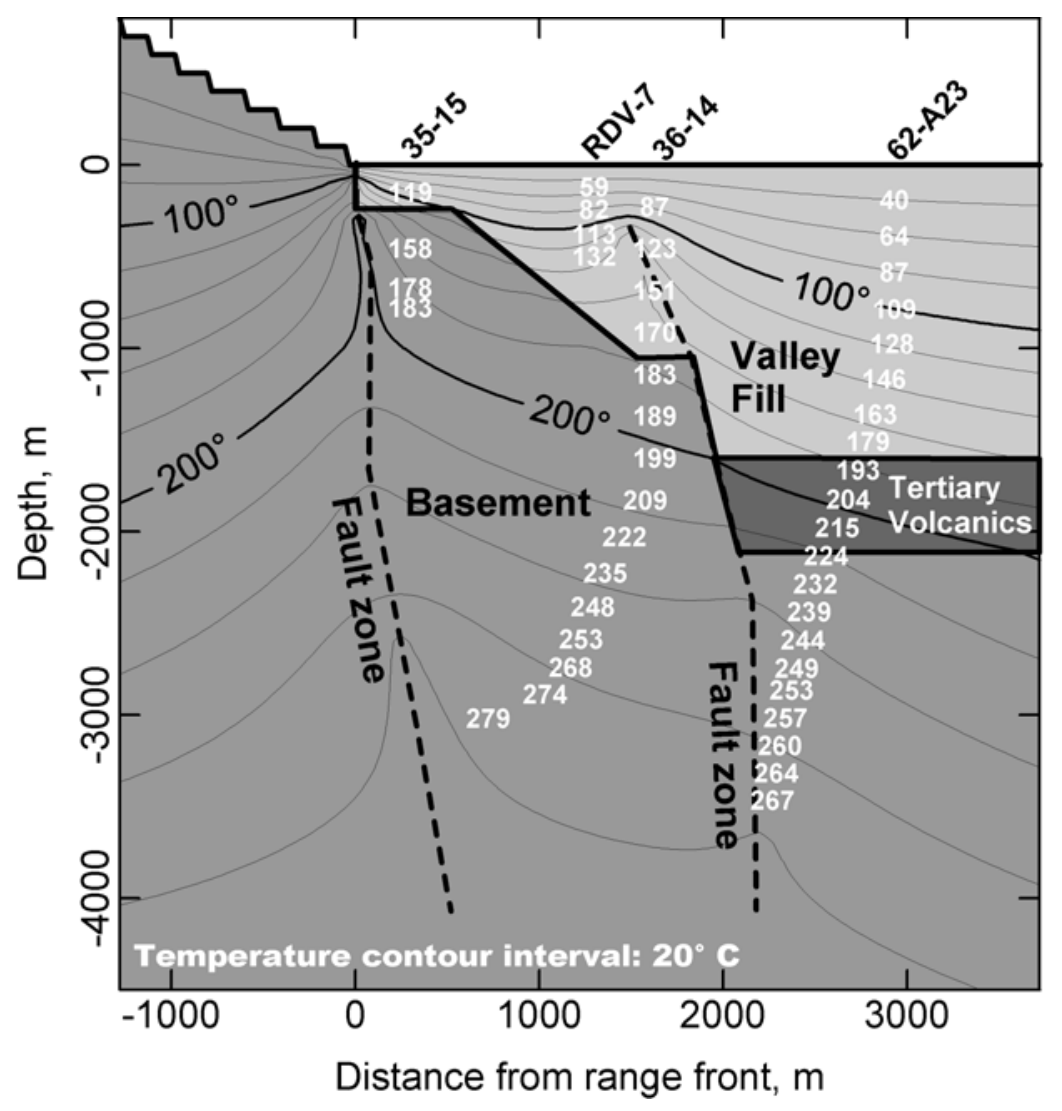

Figure 6.1. Structure and thermal cross section of the DVPP area (Blackwell et al., 2000). 


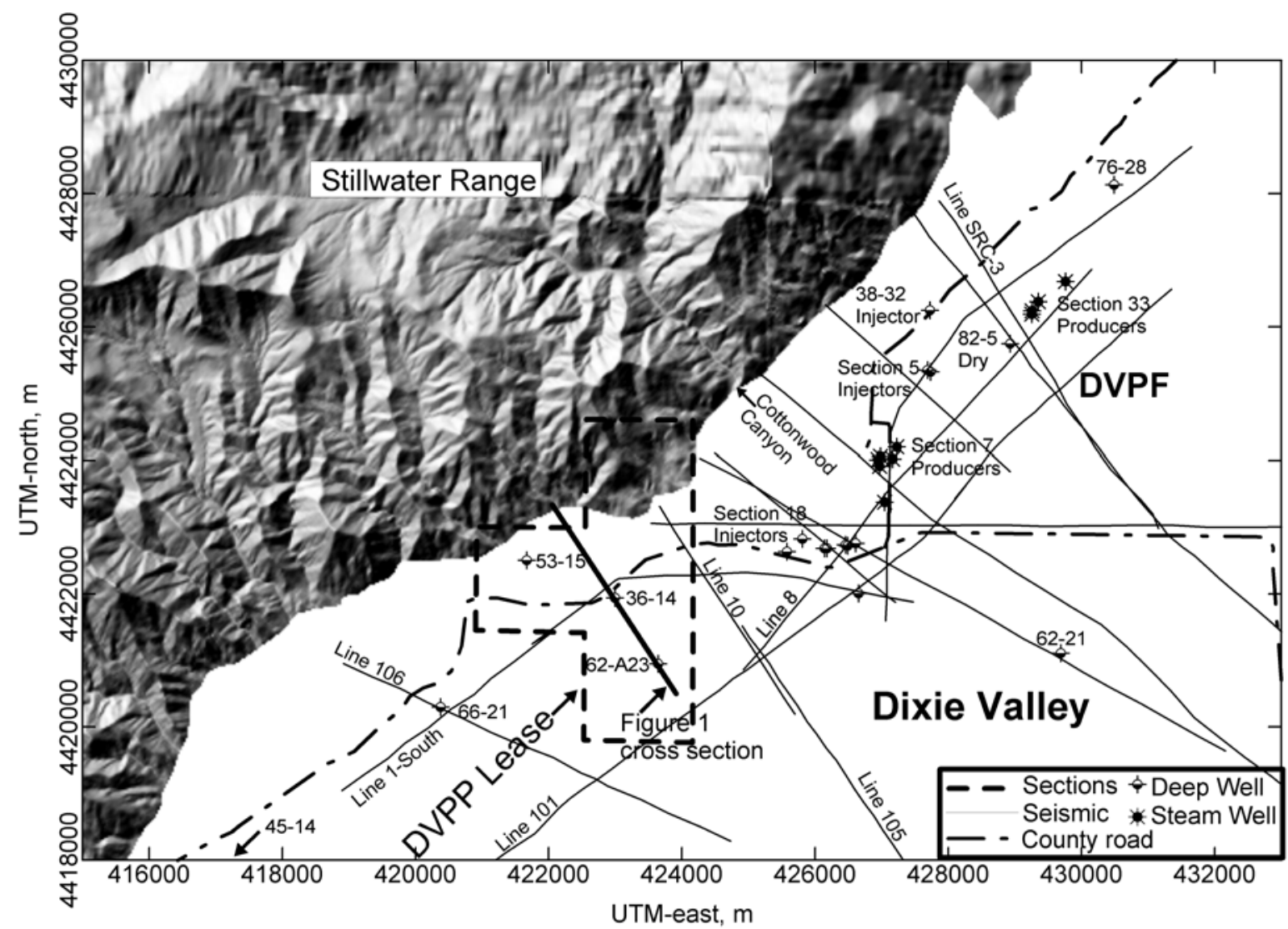

Figure 6.2. Index Map of the Dixie Valley geothermal field. DVPF is the Dixie Valley Producing Field area.

The Dixie Valley Producing Field (DVPF) has been described by Benoit $(1992,1999)$. This portion of the field was developed between 1979 and 1988 and for the last 14 years about $60 \mathrm{MW}$ of electrical power has been produced by Oxbow Power (since 2000 by Caithness). The field consists of two groups of production wells in sections 33 and 7 (Figure 6.2), with injection wells in between (section 5) and to the south (section 18 and Lamb Ranch). The DVPF has the highest temperatures $\left(248^{\circ} \mathrm{C}\right)$ found in the province in a nonmagmatic system. Temperatures reach $285^{\circ} \mathrm{C}$ in well $36-14$ immediately south of the DVPF. Wells outside the field include two hot wells located several $\mathrm{km}$ to the southwest. Wells $66-21\left(218^{\circ} \mathrm{C}\right)$ and $45-14,\left(195{ }^{\circ} \mathrm{C}\right)$ both have above regional temperatures and have a few $1 \mathrm{pm}$ of artesian flow. Temperatures in the northernmost well, 76-28 (Tmax of $162{ }^{\circ} \mathrm{C}$ at $2350 \mathrm{~m}$ ), and well 62-21 in the middle of the valley (Tmax of $184^{\circ} \mathrm{C}$ at $3318 \mathrm{~m}$ ) appear to approach background conditions (see Williams et al., 1997 for temperature-depth curves for several wells).

The models of the range bounding fault within the Dixie Valley geothermal field span the gamut from low angle or listric (Plank et al., 1999) to typical "high" angles (50 to 60 , e.g. Okaya and Thompson, 1985; Benoit, 1992). In spite of the large amount of drilling into the fault zone the production and injection wells are all about the same distance from the range/valley contact and produce from about the same depth. As a result the dip of the structures associated with the production is constrained by drilling information only between depths of 2.5 and $3 \mathrm{~km}$. Consequently, the working model of the system was a single fault dipping at about $54^{\circ}$ with small synthetic and antithetic faults in the deep valley in the hanging wall of the major fault. This $54^{\circ}$ dip was based on the assumption that the fault encountered in the producing wells connects to the range/valley topographic 
contact. This result seemed to be consistent with abundant seismic reflection data and other information (e.g. Okaya and Thompson, 1985).

\subsection{Exploration Data and Interpretation}

There are several generations of exploration data that can be compared. The original exploration focus on the area was by Southland Royalty and Sun. They centered their activities along the range front between the Stillwater Range and Dixie Valley from the Dixie Comstock area to the Senator fumaroles. Much of the Southland Royalty data was made public in the Industry Coupled DOE program of the early 1980's. Included were seismic, gravity, and aeromagnetic data. The maps were generally at a scale of $1 "=1$ mile.

Sun also collected a variety of geophysical data including gravity, aeromagnetic, electrical, and seismic reflection data. The initial Sun discovery wells (Lamb Ranch \#1,2,3) were drilled on private land and this had a large impact on the locations and the subsequent follow-up drilling. Seismic reflection data played a part in the selection of the targets.

Following Sun, a number of companies were active in the area, but generally confined their activities to production drilling. Wells drilled, including those that expanded the producing area to section 7, discovered the producing area in section 33 and defined the apparent north end of the field (76-28). Following the acquisition of the field by Oxbow a number of production and injection wells were drilled in the areas of section 7 and section 33. There was no other significant drilling activity until 1993/94 when DVPP (Caithness and Florida Power and Light) drilled the 62-23, 62A-23, and 3614 wells in an area between the Lamb Ranch wells, and the Southland Royalty 66-21 well and proved the existence there of high temperatures and fluid flow (Figure 6.1 and 6.2).

Seismic Results A wide variety of seismic exploration techniques have been applied in Dixie Valley. Early studies included refraction profiles widely distributed in the valley (Thompson et al., 1967). During the exploration phase of the late 1970's and early 1980's many kilometers of conventional seismic reflection surveys were collected using dynamite sources. The lines available are shown on Figure 6.2. An influential early interpretation of one of these profiles (SRC-3) was published by Okaya and Thompson (1985). There was later reprocessing of the seismic reflection data in 1993/94 and 1998/99. In the 1993/94 study several lines (106, part of 101, 10 and 105, Unpublished, Caithness Report, 1994) were conventionally migrated. In the later study (Lettis et al., 1998) Kirchof migration techniques were applied to a number of the lines in the northern part of the system. The seismic lines have been successful in showing generalized structure in the valley, but are not very useful for illuminating the fault style details important for exploration because of the difficult setting.

To illustrate the effects seen on the various profiles, Line 10/105, the SE-NW line that runs between the Lamb Ranch wells and the DVPP wells, is discussed in this section. The lines have been combined because both are short and cover complementary areas. The reason to use them as examples is that both migrated and unmigrated versions of the lines are available. These lines also cross the SRC-1S and 101 NE-SW lines so that the inferences from the lines can be directly correlated with other parts of the data set. The merged migrated lines are shown in Figure 6.3. An interpreted summary line drawing of this profile converted to depth is shown overlaid on a structural model in Figure 6.4.

The most prominent feature of the migrated lines is the presence of a clearly imaged valley fill. The thickness of the valley is greatest between SP's 145 and 245. The prominent reflector at about 1.1 seconds two way travel time (TWTT) is interpreted to be the top of the Tertiary basalt (see Okaya and Thompson, 1985). The basalt is close to the basement based on the Lamb Ranch wells and 


\section{Line 10}

Line 105 Migrated

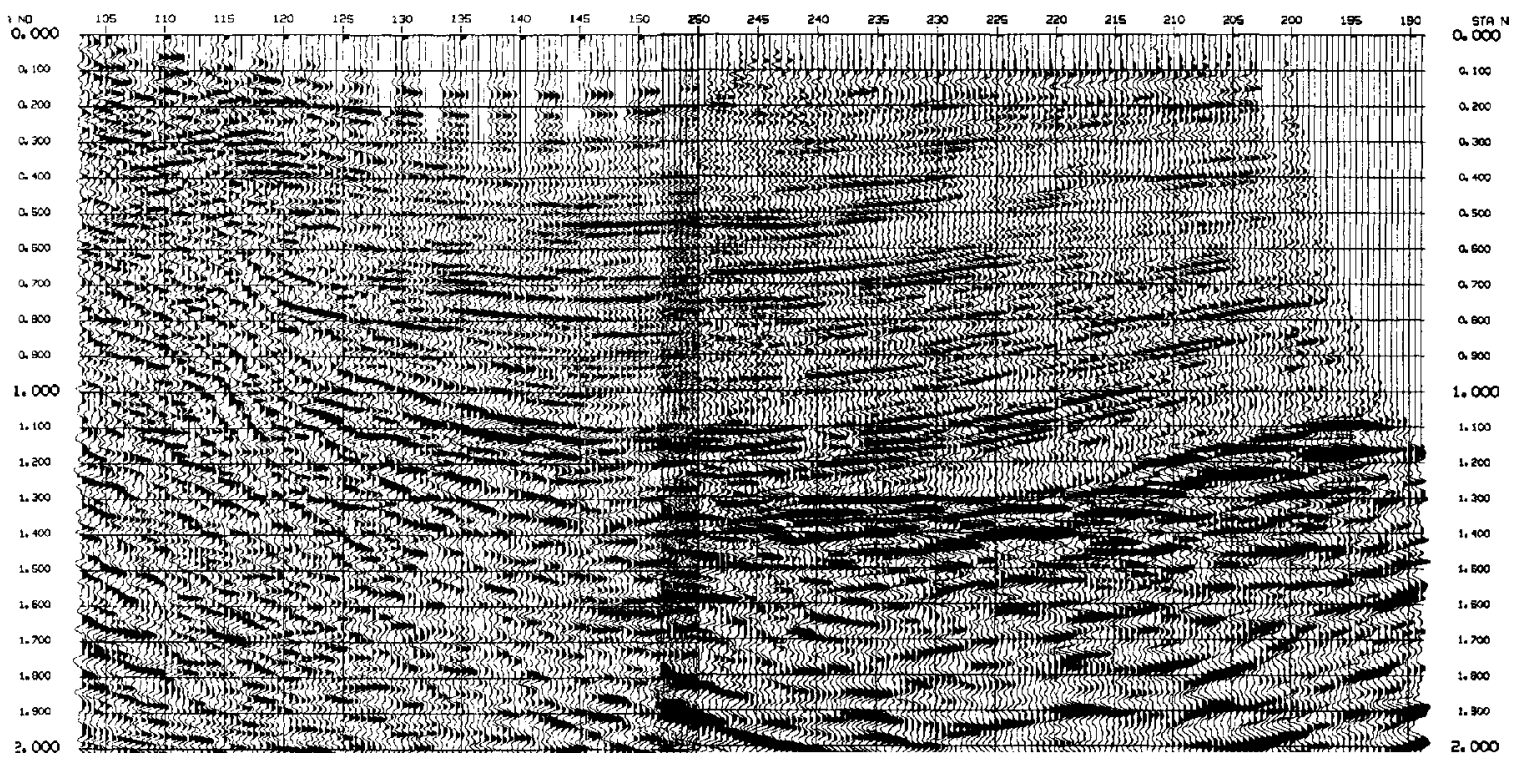

Figure 6.3. Seismic reflection lines 10/105 combined.
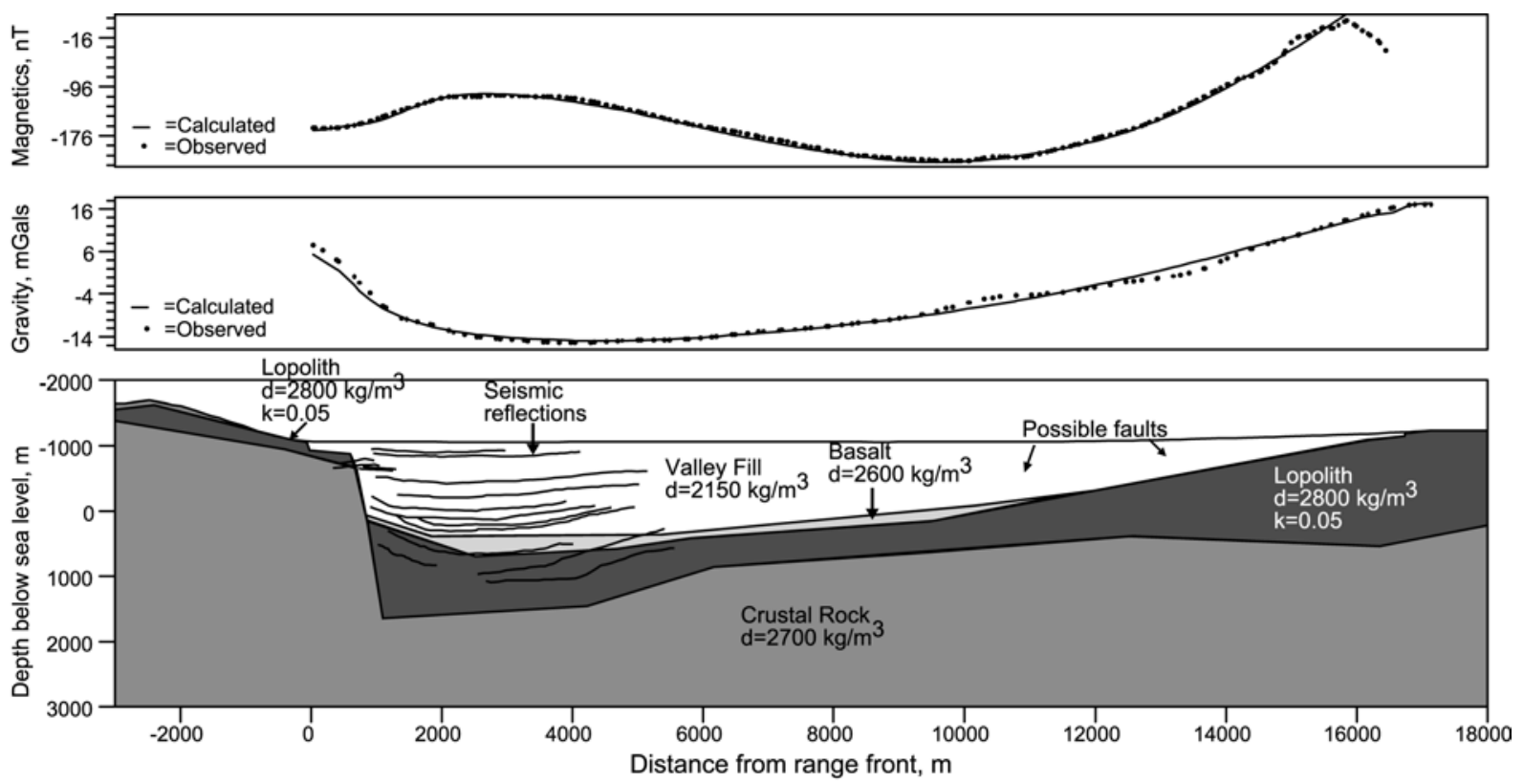

Figure 6.4. Depth section for seismic reflection lines 10/105 superimposed on gravity and magnetic cross sections.

the section 18 wells immediately to the northeast (Benoit, 1992). The second prominent reflector along the eastern part of the sections at $1.3 \mathrm{~s}$ (west) to $1.1 \mathrm{~s}$ (east) is interpreted to be the top of basement reflector. Although the data quality is poor, it shows reflectors as shallow as 0.16 seconds, but generally between 0.2 and 0.3 seconds.

A major feature of the section is the termination of most of the valley reflectors at about SP 120 on Line 10 . West of this point there are coherent reflectors above about $0.4 \mathrm{~s}$ only. The reflection 
section SRC-3 described by Okaya and Thompson (1985) is about $4 \mathrm{~km}$ northeast along the range front. It closely resembles these sections. Okaya and Thompson (1985) interpreted the similar western end of SRC-3 to represent loss of reflection coherency due to coarse alluvial fill. They furthermore thought that they saw signals from the range bounding fault dipping at about $54^{\circ}$ in the data.

Similar terminations of reflector packages are present on most of the NW-SE trending seismic lines. The positions along the seismic lines where basement reflections could be identified are shown in Figure 6.5 by the diamonds along the lines. Also shown on Figure 6.5 is the calculated gradient of the residual Bouguer gravity field. It is clear that the seismic reflection termination points and the maxima of the residual gravity gradient coincide. This coincidence implies that the situation shown for sections 10/105 is true for the area of the producing field as well as the DVPP area, i.e. the piedmont fault is located by both the gravity and seismic data in the same place. Geologic mapping from air photos shows that there are often fault scarps and small grabens at the surface over the gravity gradient maxima (Smith et al., 2001). On at least one of the seismic sections, 106 to the south, a large, deeply buried antithetic graben is imaged along the piedmont fault.

A simple example of the correlation of the gravity anomaly and the gravity gradient is shown for the 10/105 cross section data in Figure 6.6. Two generic models that satisfy the gravity anomaly and the gravity gradient pattern are shown. The peak of the gravity gradient is approximately coincident with the position of the main valley-bounding fault where it starts to displace the basement against valley fill.

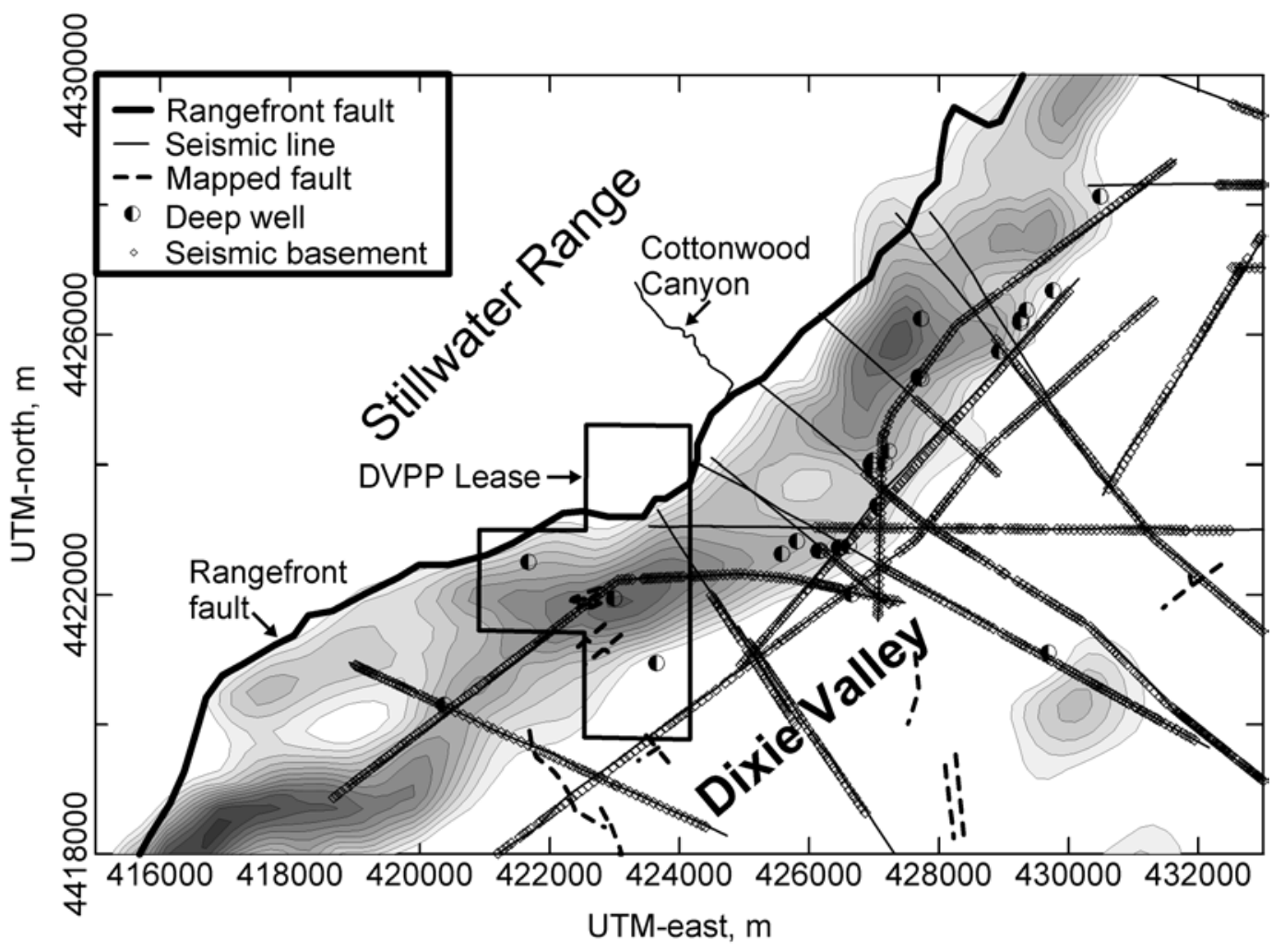

Figure 6.5. Comparison of location of steepest gravity gradients, mapped faults from air photos, and seismic reflection terminations for the area of the geothermal field. The diamonds on the seismic lines represent basement picks. 

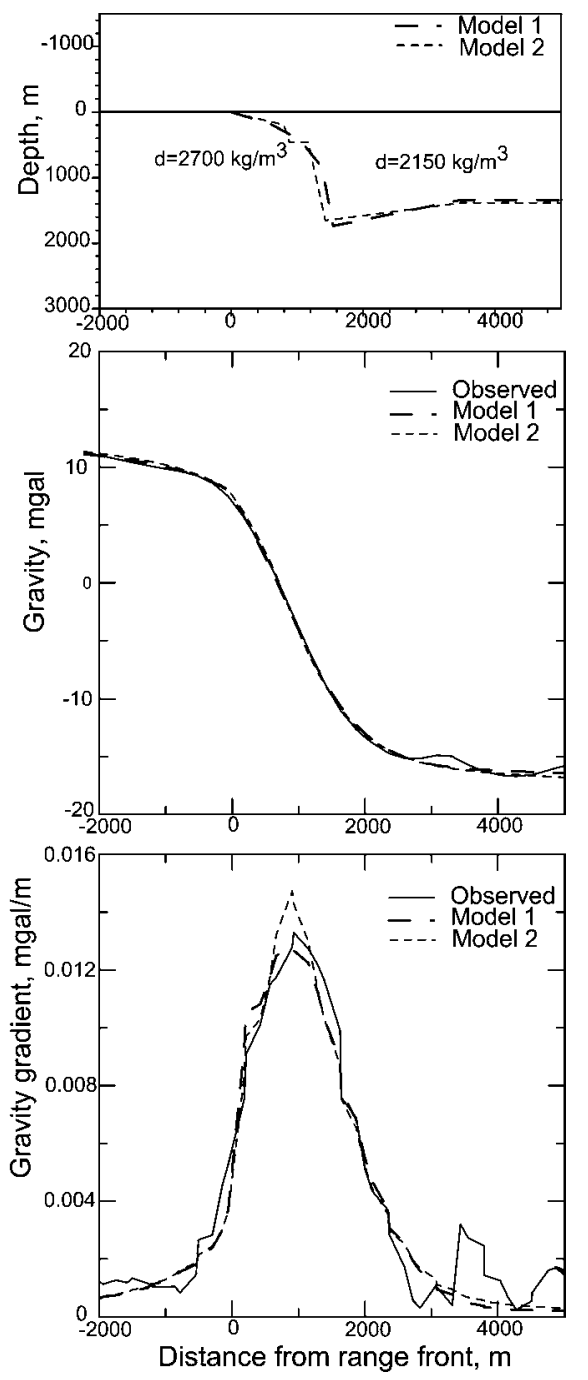

Figure 6.6. Example gravity gradients from example range front structures.

A version of the lines $10 / 105$ is shown converted to depth in Figure 6.4. The depth conversion was made using a velocity versus depth relationship based on sonic well logs and matches the lithology section as drilled in the deep wells near the seismic lines. In converting from two way travel time (TWTT) to depth we have used a conversation in the valley fill of $0.5 \mathrm{~s}$ $\sim 500 \mathrm{~m}, 1.0 \mathrm{~s} \sim 1.2$ to $1.4 \mathrm{~km}$, and $1.2 \mathrm{~s} \sim 1.5$ to $1.8 \mathrm{~km}$.

Problems with Seismic Data There are several problems with the seismic reflection data that are available and some problems that are endemic to the technique. The sections generally have not been migrated using modern techniques. The reflection technique does not deal well with steep structures and in the real case the faults generally have very steep dips. There are strong lateral and vertical velocity variations that complicate the interpretation. There are numerous examples of out-of-plane reflections on the sections as well because of the 3dimensional velocity configuration.

The most enigmatic feature of the sections is the noise in the vicinity of the Lamb

Ranch injection wells and the section 7 production wells. This "noise" is particularly clear on the Lines 8 and SRC-1N. This area is enigmatic since the drill data from the wells does not indicate anything anomalous about the valley in this area. One possibility is that the noise is due to side swipes from a buried fault scarp along the piedmont fault just to the northwest of the line. Another possibility is an area of pull up because of induration or alteration of the valley fill, maybe due to silicification.

Gravity Data A detailed gravity compilation for this area of Dixie Valley was described by Blackwell et al. (1999). These data were used to generate residual maps of the field area. A detailed interpretation of the section along the seismic lines 10/105 is shown in Figure 6.4. This section includes an interpretation of both gravity and magnetic data. A single density contrast of $-0.55 \mathrm{gm} / \mathrm{cc}$ was used for the valley fill relative to basement and a positive density contrast of $+.10 \mathrm{gm} / \mathrm{cc}$ for the lopolith relative to the basement.

Magnetic Studies Aeromagnetic surveys were carried out by both Sun and Southland Royalty in the late 1970's and early 1980's. More recently in early 2002 a high-resolution low-altitude aeromagnetic study was carried out (Smith et al., 2002) based on success in imaging shallow expressions of intrabasin faults in the Albuquerque Basin (Grauch et al., 2001). That survey is described by Smith et al. (2002). It was very successful in locating faulting trends along the east side of the valley, but was less successful along the deeper west side. 
Interpretation Both the gravity and the magnetic data on the profile along seismic lines 10/105 are shown in Figure 6.4. The total field aeromagnetic data from a 1979 survey flown at an elevation of $5500 \mathrm{ft}(1676 \mathrm{~m})$ are shown. There is an excellent correlation on the regional scale between the two sets of data. Areas of high gravity along the east side of Dixie Valley correspond to the areas of positive magnetic field strength. Both of these in general, correspond to areas probably underlain by the Jurassic Humboldt lopolith (see Smith, 1968). For example, there are two generally circular areas in Dixie Valley where the contours of the residual gravity field follow the contours of the magnetic field and both are clearly related to lopolith bodies that are mostly buried. Therefore, the mafic rocks of the lopolith are both dense and magnetic. Weaker positive magnetic anomalies, not so clearly related to gravity, are located along the west side of the valley. The magnetic anomalies on both sides of the valley are on the section shown in Figure 6.4. Only the lopolith was assumed to be magnetic in modeling the section.

\subsection{Discussion}

The drilling described by Blackwell et al (2000) in the DVPP area to the south, the drilling in section 18, and the gravity interpretation show that the point where the reflectors end on Figure 6.3 is the location of the piedmont fault. The fault there has about $0.6 \mathrm{~s}$ of displacement as shown on Figure 6.4. In these areas the range bounding fault and the piedmont fault dip at an angle of greater than $80^{\circ}$ and carry fluid at temperatures of $240-285^{\circ} \mathrm{C}$. Most of the rest of the sections perpendicular to the range valley contact show clear valley reflectors to a certain point and then have no clear reflections from there to the range end of the line. Both gravity and drilling show that the "alluvial fan" of Okaya and Thompson (1985) is actually a shallow basement block in between a piedmont fault and the range front fault.

Given the present understanding of the Dixie Valley field, what might be the optimum approach to developing the field? The results described above show that there is no magic bullet. The seismic reflection data are very useful and can be site specific when a profile is in the right place, but are sparse, very difficult to interpret correctly, and expensive to collect. The velocity values used are uncertain even though there are several sonic logs for the wells. A VSP, Vertical Seismic Profile, survey would significantly improve the precision of the interpretation. The gravity data are not as site specific as the seismic, but put the major parts of the structure in their proper location and places vital constraints on the possible interpretations of the seismic data. The high resolution aeromagnetic technique was very successful along the east side of the valley, but less along the geothermally important west side. Detailed correlation will be investigated when the high resolution data are available. The magnetic results will also vary from area to area depending on the local rock types more than in the other techniques. Nonetheless important information on the style of the faulting is contained in the data. Geologic mapping from air photos in some places clearly located the structures in the valley and hence is very site specific. None of the techniques were very successful in determining the strike of the fracturing and faulting between the piedmont and range front faults in a useful way. This is a problem since a large volume of reservoir is included in this area. The single most useful data set might be a high resolution 3-d or closely space 2-d seismic survey focused on the depth range of 500 to $1500 \mathrm{~m}$ and covering the piedmont area. We are investigating the design and costs of such a survey to help resolve the uncertainties in the structure of the piedmont/range zone.

\subsection{References}

Benoit, D., A case history of injection through 1991 at Dixie Valley, Nevada, Geothermal Resources Council Trans., 16, 611-620, 1992. 
Benoit, D., A review of various conceptual models of the Dixie Valley, Nevada geothermal field, Geothermal Resources Council Trans., 23, 505-511, 1999.

Blackwell, D.D., Golan, B., and Benoit, D., Thermal regime in the Dixie Valley geothermal system, Geothermal Resources Council Trans., 24, 223-228, 2000.

Blackwell, D.D., Leidig, M., Smith, R.P., Johnson, S., and Wisian, K.W., Exploration and development techniques for Basin and Range geothermal systems: Examples from Dixie Valley, Nevada, Geothermal Resources Council Trans., 26, 513-518, 2002.

Blackwell, D.D., Wisian, K.W., Benoit, D., and Golan, B., Structure of the Dixie Valley geothermal system, a "Typical" Basin and Range geothermal system, from thermal and gravity data, Geothermal Resources Council Trans., 23, 525-531, 1999.

Grauch, V.J.S., Hudson, M.R., and Minor, S.A., Aeromagnetic expression of faults that offset basin fill, Albuquerque Basin, New Mexico, Geophysics, 66, 707-720, 2001.

Lettis et al., Application of advanced seismic reflection techniques to mapping permeable zones at Dixie Valley, Nevada, Final Report, NTIS \#DE98005072INZ, 77 pp., 1998.

Okaya, D.A., and Thompson, G.A., Geometry of Cenozoic extensional faulting: Dixie Valley, Nevada, Tectonics, 4, 107-125, 1985.

Plank, G., Schweickert, R., Benoit, D., and Simmons, A., Influence of fault surface geometry on the location of the Dixie Valley geothermal area, Dixie Valley, Nevada, Proceedings, Twentyfourth Workshop on Geothermal Reservoir Engineering, Stanford University, January 25-27, 6 pp, 1999.

Smith, R. P., Grauch, V.J.S., and Blackwell, D.D., Preliminary results of a high-resolution aeromagnetic survey to identify buried faults at Dixie Valley, Nevada, Geothermal Resources Council Trans., 26, in press, 2002.

Smith, R.P., Wisian, K.W., and Blackwell, D.D., Geologic and Geophysical evidence for intra-basin and footwall faulting at Dixie Valley, Nevada, Geothermal Resources Council Trans., 25, 323326, 2001.

Smith, T.E., Aeromagnetic measurements in Dixie Valley, Nevada; Implications on Basin-Range structure, J. Geophys. Res., 73, 1321-1331, 1968.

Speed, R., Geology of the Humboldt lopolith \& vicinity, Geol. Soc. Amer. Map MC-14, Boulder, Colo., 1976.

Williams, C.F., Sass, J.H., and Grubb, F.V., Thermal signature of subsurface fluid flow in the Dixie Valley geothermal field, Nevada, Proc. $22^{\text {nd }}$ Annual Workshop on Geothermal Res. Eng., Stanford Univ., pp. 161-168, 1997. 


\section{Section 7. Insights Into Extensional Geothermal Systems from Numerical Modeling}

\subsection{Introduction}

There are two major similarities in extensional systems of the Basin and Range: (1) strongly fault-related near-surface upflow, and (2) lack of any evident crustal magmatic heat sources (Yeamans, 1983). While there is general agreement that the upflow in most Basin and Range geothermal systems is fault controlled, the effect of the permeability structure on systems is still debated (Wright, 1991). These non-magmatically driven, fault controlled geothermal systems are termed extensional systems in this report.

Most studies of extensional systems, including those based on numerical modeling, have focused on the near-surface reservoir with a view towards reservoir exploitation (Sorey and Olmstead, 1994). The generally accepted qualitative models of extensional systems postulate fluid circulation predominately perpendicular to, and occasionally within the range-front fault. There has been little effort to systematically determine the basic relationships between system configuration (e.g. permeability and structure) and the resulting thermal-flow behavior of the geothermal system). Notable exceptions are the studies of Forster and Smith (1988a\&b, 1989), which considered mountainous terrain systems, and Lopez et al. (1994, 1995, 1996), Welch, Sorey and Olmsted (1981), and Sorey and Olmsted (1994), which simulated three-dimensional systems with a focus on in-thefault-plane circulation.

Heat and water, two prime ingredients for a geothermal system, are present throughout the Basin and Range. Permeable upflow paths are also needed in order for the heated water to return quickly to the shallow sub-surface. Faulting provides these paths. The Basin and Range is heavily faulted throughout, so why then are geothermal systems only associated with relatively recent faulting? The answer is that self-sealing - the process where cooling, ascending fluids precipitate minerals in pore space (thereby reducing permeability) - will eventually limit or eliminate flow.

Field studies have found extensive sealing in exhumed faults. Parry et al., (1991) found extensive hydrothermal alteration and fracture filling at all scales on the exposed footwall of the Dixie Valley fault, south of the commercial plant. Similar pervasive geothermal alteration and sealing has been found on other faults in the region (Parry et al., 1988; Vikre, 1989). Precipitation would be orders-of-magnitude faster on the lateral boundaries of a flow conduit than along its length due to steeper temperature and pressure gradients. Thus it is likely that a conduit such as a fault would, for most of its lifetime, have low permeability lateral barriers.

\subsection{Methods}

The numerical code used to solve the coupled, non-linear equations of heat and fluid flow was TOUGH2. The code has been verified, as defined by Anderson and Woessner (1992). TOUGH2 (Transport Of Unsaturated Groundwater and Heat 2) is a multi-dimensional, Integrated Finite Difference (IFD) code for fluid and heat flow (Pruess, 1987, Pruess, 1991a). TOUGH2 is a refinement of the MULKOM code system developed at Lawrence Berkeley Laboratory. For this study a slight change was made to the published version of TOUGH2 for PC's. The maximum number of elements and connections was increased to accommodate the models in this study. A bibliography relating to TOUGH2 is available on the internet at http://ccs.lbl.gov/TOUGH2/BIBLIOGRAPHY.html. This site is part of a home page for information relating to TOUGH2. The FORTRAN77 source code for TOUGH2 is available (for a fee) from the Department of Energy. All the work for this study was performed on Pentium based PCs. Processor speeds varied from 90 to $200 \mathrm{MHz}$, and RAM ranged 
between 32 and 64 Megabytes.

The majority of the models covered a broad range in basal heat flow (30 to $120 \mathrm{~mW} / \mathrm{m}^{2}$ ) and host rock permeability configurations $\left(10^{-15}\right.$ and $\left.10^{-18} \mathrm{~m}^{2}\right)$. Host rock is taken to be all rock except the valley fill and fault zone. Other series were run to evaluate fault permeability $\left(3.0^{*} 10^{-15}\right.$ to $2.0^{*} 10^{-12}$ $\left.\mathrm{m}^{2}\right)$, rock thermal conductivity $(0.8-3.0$ times the base configuration), degree of self-sealing along the upflow path $\left(10^{-15}\right.$ and $\left.10^{-18} \mathrm{~m}^{2}\right)$, and valley fill permeability (ratios of horizontal to vertical permeabilities between 1 and 100). In all models, all rock properties, including porosity and permeability are constant within a given unit. In other words there is specifically no variation with depth or time (e.g. compaction or consolidation). All rock unit properties are also isotropic except for valley fill permeability.

The base model used in this report consists of a vertical cross section of a generic Basin and Range valley (Figure 7.1). The model is $27 \mathrm{~km}$ wide by $8.75 \mathrm{~km}$ deep (top of range to bottom of the model). The model has 4782 cells (or elements) and 4932 nodes. Elements range in size from 5762 $\mathrm{m}^{2}$ in the fault zone to $30,1872 \mathrm{~m}^{2}$ outside the area of interest (the models are assigned a thickness of one meter). While TOUGH 2 can handle $n$-sided cells, all modeling was conducted with rectangular elements due to limitations with meshing algorithms in the Argus ONE software used to create the models.

The model domain is larger than often seen in system studies - it extends beyond the range and valley of interest to include part of the next range and valley to either side. The ranges are $5 \mathrm{~km}$ wide at the base and have a relief of $0.75 \mathrm{~km}$. The valley floor is horizontal, and $9 \mathrm{~km}$ wide (Figure 7.1). These dimensions are representative of a typical basin and range.

The fault zone is planar, and dips $60^{\circ}$. The $60^{\circ}$ dip was chosen to be representative of the upper portion of a typical Basin and Range fault. The fault extends to $4 \mathrm{~km}$ below the valley floor. This fault depth is somewhat less than might be expected for a typical fault. The fault depth was a compromise between the desire to allow for ample room below the base of the fault for fluid and heat flow such that the bottom boundary would not be abruptly truncating flow paths, and the need to keep the model less than $9 \mathrm{~km}$ tall (due to the limits of the equation of state module). The surface break of the fault is at the base of the range, in the valley. There are separate zones on each side of the fault that are used to represent barrier zones. These barrier zones can be used to simulate self-sealing. The

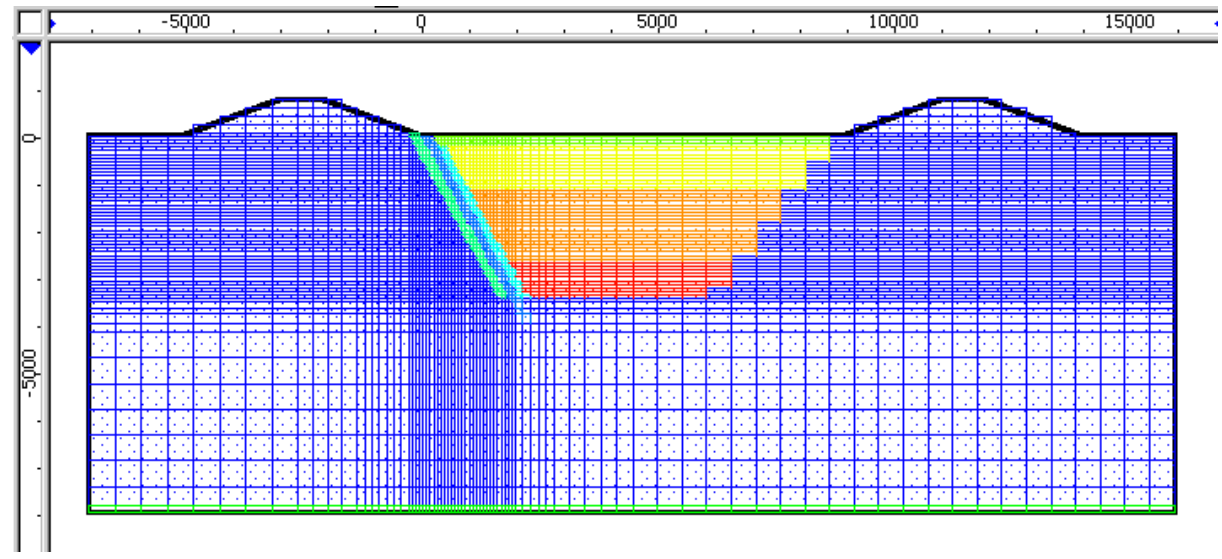

Figure 7.1. Model Mesh. Model dimensions are in meters. The bulk of the model consists of one rock unit (dark). The valley fill is divided into several units (shades of gray), but was treated as one for all cases. The fault zone is bracketed by barrier zones. Apparent gaps in element spacing in the high-density regions are a display artifact. 
valley fill was divided into several layers to provide the capability of representing shallow outflow zones, but for the models reported here, the valley fill was treated as one unit (i.e. all four layers had identical properties).

Boundary conditions for all TOUGH2 models are as follows:

Top set at a constant pressure of $1 \mathrm{E}+05 \mathrm{~Pa}$ (atmospheric) and temperature of $20^{\circ} \mathrm{C}$

Sides set at no heat or fluid-flow

Bottom set at no fluid-flow, with constant heat flux into the model.

The top boundary was set at representative surface conditions. No thermal lapse rate was included, as this would have an insignificant effect on the model. The water table was set at ground level in the model. No attempt was made to represent the unsaturated zone. The complexity that would be added to the model by representing the near surface environment in detail would add little to the understanding of a generic geothermal system.

Initial conditions for the first model run in all series were a roughly linearly increasing (hydrostatic) pressure and temperature with depth. For subsequent runs in a series, the solution of the first run was used as the starting point. As a check some models were run from both sets of initial conditions. In these runs there was no difference in the final (steady state) solution. Default iteration and solution criteria, as defined in Pruess (1987, 1991a), and Moridis and Pruess (1995), were used in all models.

\subsection{Results}

Representative model results for a basal heat flow of $90 \mathrm{~mW} / \mathrm{m}^{2}$ and $10^{-16} \mathrm{~m}^{2}$ bulk permeability, are shown in Figures 7.2, and 7.3. The primary flow path in most models is from the ranges, to the bottom of the fault, and up. Secondary flow systems are present on the flanks of the ranges and in the valley fill. Most of the fluid circulates to depths below the bottom of the fault. Isotherms are depressed under the ranges and elevated near the fault (as would be expected). Figure 7.4 shows temperature-depth curves at various locations in the model. The character of the temperature-depth curves are dependent on where they are in relation to the upflow. Plots that cross the fault zone show an inflection of varying sharpness depending distance from the fault surface break. Note that temperature-depth plots from the range show only subtle indications of fluid recharge (the shallow isothermal section).

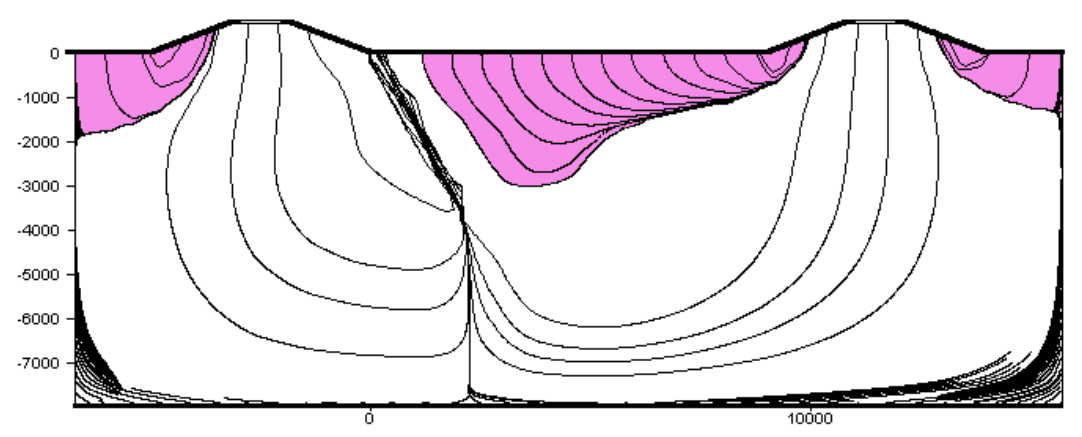

Figure 7.2. Flow paths for typical TOUGH2 model. Representative particle paths are shown (not stream functions). The bulk of the flow circulates to 4 to 7 kilometers depth before returning to the surface. The shallow flow systems (shaded) reach no deeper than $2 \mathrm{~km}$ in most models. 


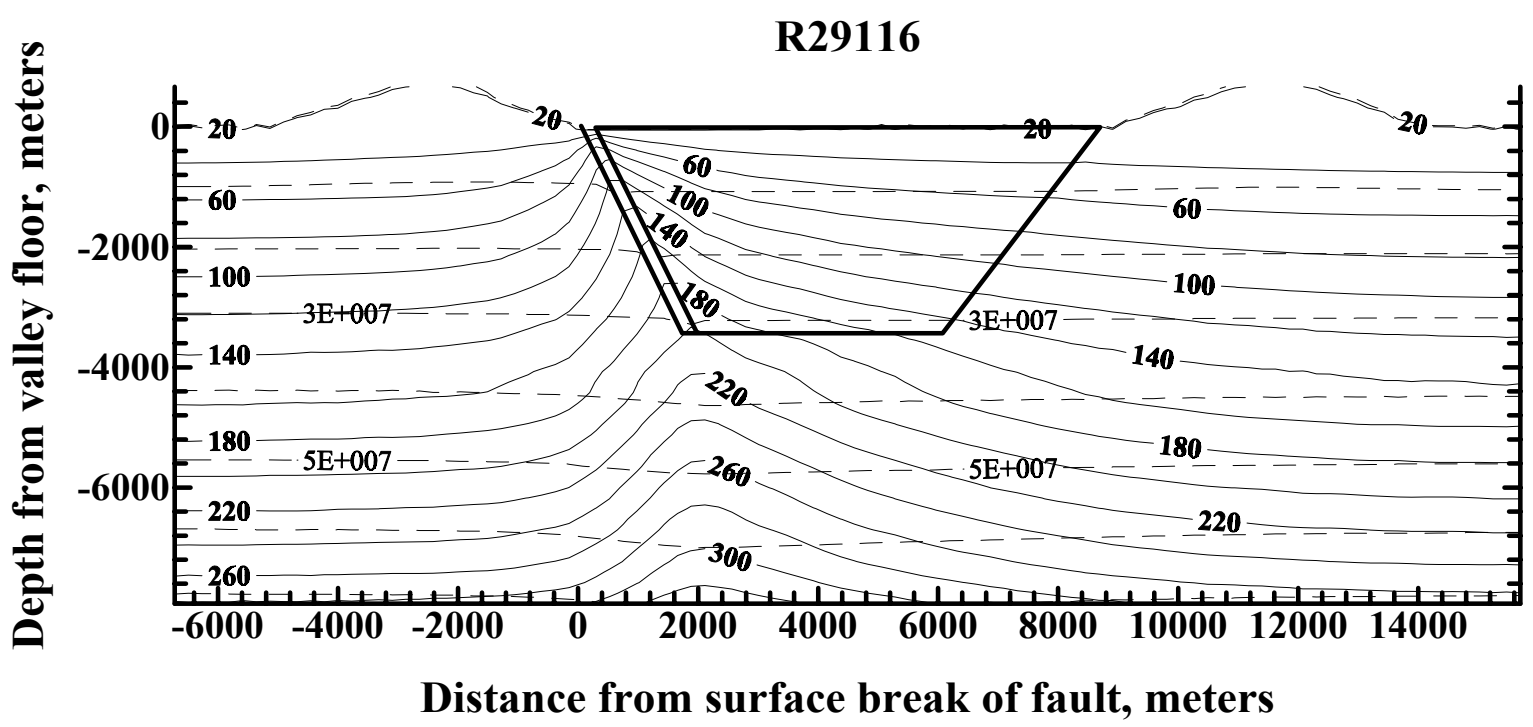

Figure 7.3. Temperatures and pressures in model R29116 $\left(90 \mathrm{~mW} / \mathrm{m}^{2}\right.$ basal heat flow, $10^{-16} \mathrm{~m}^{2}$ bulk rock permeability). At this permeability, the thermal regime is between convection and conduction dominated states. The isotherms show significant depression under the ranges and pull-up in the fault due to fluid flow.

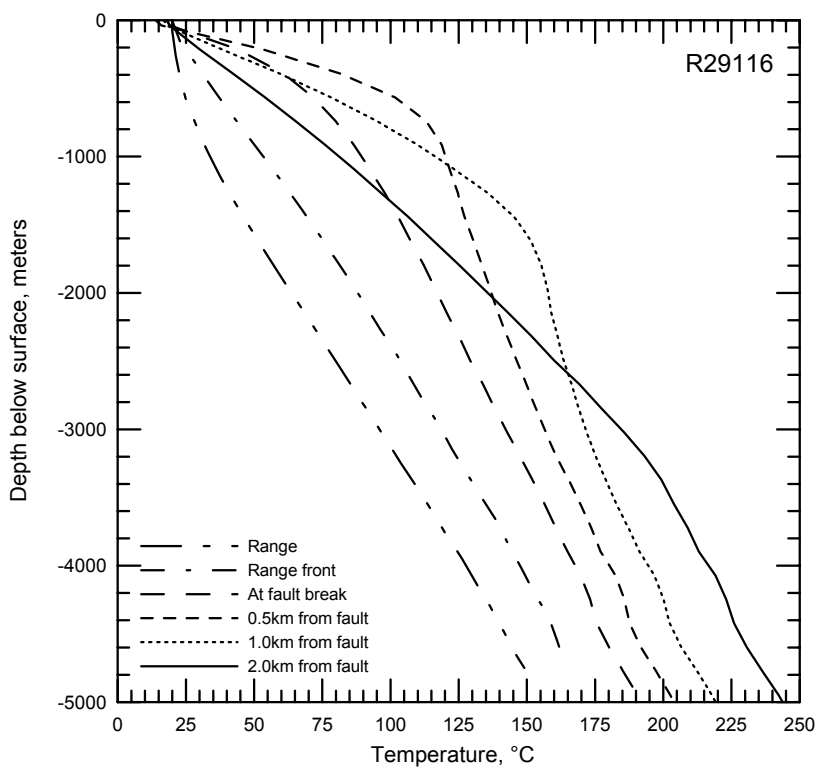

Figure 7.4. Temperature-depth curves for various locations in model R29116. Fluid upflow is clearly recognizable in the T-D plots from the fault and further into the valley. Even though there is strong downflow under the ranges, the range and range front T-D curves look qualitatively similar to conduction dominated cases.

Before starting to discuss results for all the model series, it is necessary to determine what output is of interest. Flow fields and temperature isotherms are of course important to see, but it is not possible to keep dozens of graphs in mind. A more concise measurement of the results of many models is needed. To that end, total heat flow up the fault and fault temperatures have been used as overall measures of a model.

Heat flow and temperature vary continuously along and across the fault in all models, so some rational for quantifying these values is needed. Temperature and heat flow are measured $0.5 \mathrm{~km}$ 
below the valley floor. Heat flow is determined by summing the conductive and advective heat flux across the fault. Temperature is an average of the temperature in the cells that are in the fault zone at $0.5 \mathrm{~km}$ depth (plus or minus one cell). The $0.5 \mathrm{~km}$ depth of measurement obviously impacts the values. As shallow a point as practical is desired so that, particularly for heat flow, all heat that is to be captured by the fault, is by this point. From the point of real-world applicability too, a shallow point is desired. Most temperature measurements are made in the upper one or two kilometers of the crust. Also, from an economic point of view, production is usually in the same depth range, so again it is the shallow thermal regime that is of interest. Model boundary effects and the shallow outflow zone need to be avoided when quantifying a model thermally. A depth of $0.5 \mathrm{~km}$ gets safely below the impact of any effects due to the coarseness of the air/surface interface.

The main feature apparent in Figures 7.5 and 7.6 is a peak in temperature and heat flow up the fault for bulk permeability in the $10^{-16}$ to $10^{-15} \mathrm{~m}^{2}$ range. The peaks shift to lower permeability with increasing heat flow. Maximum temperature in the fault shows more dependence on basal heat flow than the heat output of the fault. In all cases the maximum temperature occurs at a slightly lower permeability than maximum heat flow, because of a trade-off between the volume of fluid moving up the fault and the temperature of the fluid.
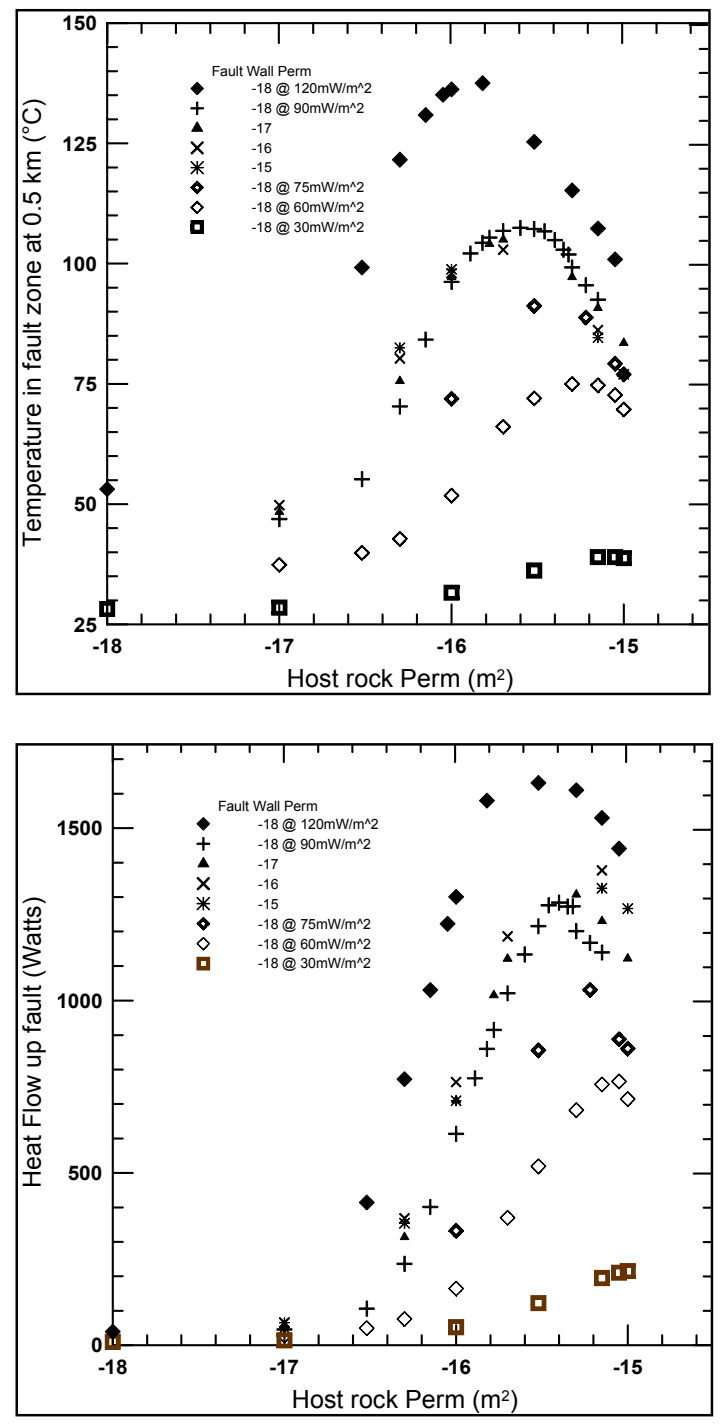

Figure 7.5. Fault temperature versus host rock permeability. At $10^{-18} \mathrm{~m}^{2}$ bulk rock permeability temperatures reflect a conductive regime. As permeability increases, so does temperature in the fault, until reaching a maximum between $10^{-16}$ and $10^{-}$ $15 \mathrm{~m}^{2}$ (depending on basal heat flow). At permeabilities higher than the peak, fluid flow is so vigorous that the models begin to "wash out" and the temperature declines.

Figure 7.6. Heat flow up the fault versus host rock permeability. The pattern is similar to that for the temperatures in the fault. 


\subsection{Discussion}

For basal heat flow 30 to $120 \mathrm{~mW} / \mathrm{m}^{2}$, temperature and heat flow in the fault versus bulk rock permeability are qualitatively similar. All start at a conductive state at $10^{-18} \mathrm{~m}^{2}$ permeability. As permeability increases, convection starts (at lower bulk permeability with increasing basal heat flow). At $10^{-17} \mathrm{~m}^{2}$, temperatures and heat flow are only slightly higher, in all cases, than at $10^{-18} \mathrm{~m}^{2}$, but by $10^{-16.5} \mathrm{~m}^{2}$ all the plots (except $30 \mathrm{~mW} / \mathrm{m}^{2}$ ) show clear increases from conductive states-indicating the onset of convection. From the start of convection, all the profiles increase steadily until the increasing convection starts to "wash-out" the system, there after the temperature and heat flow start to decrease. The decrease continues through $10^{-15} \mathrm{~m}^{2}$, the highest bulk permeability that could be practically simulated. Above this value, fluid and heat flow was so vigorous that the code reduced the solvable time step to unrealistically short increments. Similar results across a (more limited) range of permeability and heat flow have been published for a low temperature mountainous environment, by Forster and Smith (1989), as previously mentioned. Lopez and Smith (1995), found the same type of dependence for their geothermal system models. One series of models, at $90 \mathrm{mWm}^{2}$ basal heat flow, was run to evaluate the effect of self-sealing barriers. For these runs the permeability of the units on either side of the fault was varied between $10^{-18}$ and $10^{-15} \mathrm{~m}^{2}$. The resulting heat flow and temperatures in the fault show relatively little variation. Thus, as long as a permeable central path exists, the degree of self-sealing, has only a minor effect on the geothermal system (for this particular geometry).

There is a slight, but sharp decrease in temperature and heat flow up the fault, at permeabilities slightly greater than that for the peaks in the respective curves (e.g. around $10^{-15.3} \mathrm{~m}^{2}$ for $90 \mathrm{~mW} / \mathrm{m}^{2}$ basal heat flow). This drop is due to the development of secondary convection cells in the model. These cells start in the two outboard valleys when the bulk permeability is such that it is easier for the deep circulation under the valleys to exit within the valley rather than cross the range and exit at the fault. At this point the contrast between bulk and fault permeability is $\sim$ one order of magnitude. Small cells initiate (with increasing permeability) in the lower outboard corners and rapidly expand to discharge at the surface. These models show that an easy "escape path" such as a permeable fault path can induce significant cross-range flow even without a regional topographic/hydrologic slope.

To isolate the effect of topography on geothermal system development, a series of models identical to the previous $90 \mathrm{~mW} / \mathrm{m}^{2}$ basal heat flow models were run, but with no topography. For this series, the top of the model was a flat surface at the level of the valley floor. All other variables and boundary conditions are the same. Figure 7.7 shows the results of the "flat top" models in terms of Nusselt number. The Nusselt number is the ratio of heat transferred by fluid movement to that transferred by conduction. As with other non-dimensional numbers used in porous media flow, $N \boldsymbol{u}$ is defined in many subtly different ways according to circumstances. Here $\boldsymbol{N} \boldsymbol{u}$ is defined as;

\section{HFUF/HFUF@10 $10^{-18} \mathrm{~m}^{2} B P$}

Where $\boldsymbol{H F U F}$ is Heat Flow Up the Fault $0.5 \mathrm{~km}$ below the surface, and $B P$ is Bulk Permeability.

The development of the system with respect to bulk permeability is qualitatively the same with and without topography. Topography provides an extra "kick" to convection compared to flat top models. Convection starts at slightly lower permeability with topography, and is somewhat stronger. The maximum Nusselt number (and similarly the maximum heat flow up the fault) for the system with topography is $\sim 20 \%$ higher than for the flat system. Peak temperatures within the fault for the two systems are within $1^{\circ} \mathrm{C}$ (flat top systems are slightly lower). Besides being offset to higher permeability, the peak in temperature for the flat system is also broader. The occurrence of higher 
total heat flow up the fault, for the system with topography versus the system without, even though the maximum temperatures are nearly the same, indicates that the system with topography is pushing more fluid through the fault.

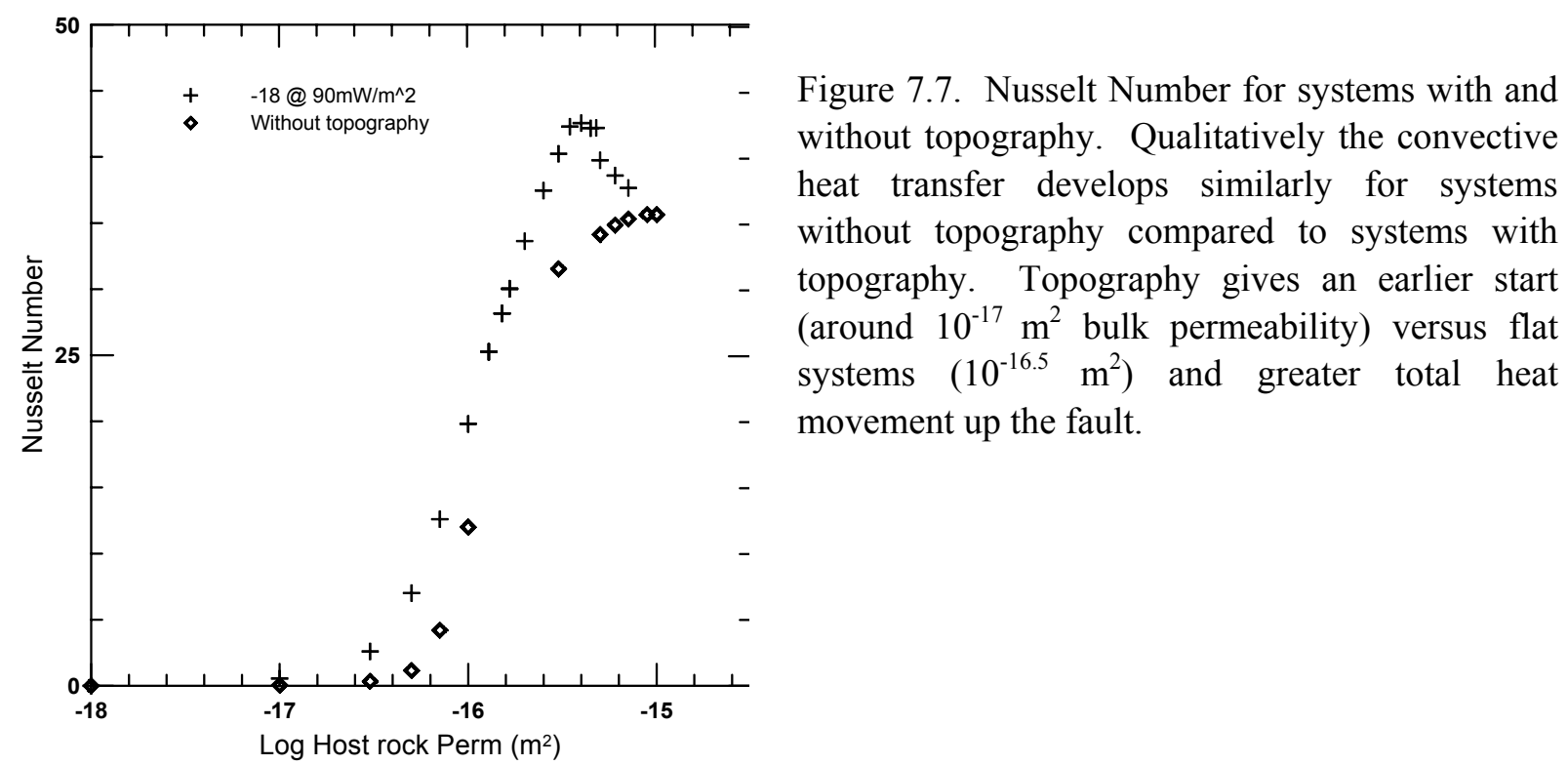

\subsection{Conclusions}

Basic qualitative relationships between structure, heat input, and permeability distribution, and the resulting extensional geothermal system have been determined based on numerical modeling of a typical basin and range. An extensional geothermal system is found to exist only in a relatively narrow range of bulk permeability $\left(10^{-15}\right.$ to $\left.10^{-16} \mathrm{~m}^{2}\right)$. Outside of this window temperatures in the shallow sub-surface decrease rapidly. The presence of a relatively permeable upflow path (provided by geologically recent faulting) is a requirement for system development. Combined with the need for above average (continental) heat flow, a fairly specific set of conditions for geothermal system development are defined.

Maximum temperatures in, and heat flow up the fault are proportional to basal heat flow (background or regional heat flow in geologic terms). While topography gives an extra, early "kick" to circulation, it is not a requirement for system development. In the generic geothermal system model, flow from the ranges to the fault dominates the circulation, while secondary flows exist on the range front slopes. A permeable fault in one valley can also induce cross-range flow from adjacent valleys if there are no equally good upflow paths in the adjacent valleys. When bulk permeability is high enough, additional deep circulation cells develop in adjacent valleys, diverting heat and fluid from the fault and consequently reducing temperatures.

While there are many factors that remain to be evaluated, the basic quantitative relationships are emerging.

\subsection{References}

Anderson, M.P., and W.W. Woessner (1992). Applied Groundwater Modeling, Academic Press, London, $381 \mathrm{pp}$. 
Forster, C., and L. Smith (1988a). Groundwater Flow Systems in Mountainous Terrain 1. Numerical Modeling Technique, Water Resour. Res., 24, pp. 999-1010.

Forster, C., and L. Smith (1988b). Groundwater Flow Systems in Mountainous Terrain 2. Controlling Factors, Water Resour. Res., 24, pp. 1011-1023.

Forster, C., and L. Smith (1989). The Influence of Groundwater Flow on Thermal Regimes in Mountainous Terrain: A Model Study, J. Geophys. Res., 94, pp. 9439-9451.

Lopez, D.L., L. Smith, and M.L. Sorey (1994). Modeling Fluid Flow and Heat Transfer at Basin and Range Faults: Preliminary Results for Leach Hot Springs, Nevada, Geothermal Resources Council Transactions, 18, pp. 11-16.

Lopez, D.L., and L. Smith (1995). Fluid flow in fault zones: Analysis of the interplay of convective circulation and topographically driven groundwater flow, Water Resour. Res., 31, pp. 14891503.

Lopez, D.L., and L. Smith (1996). Fluid flow in fault zones: Influence of hydraulic anisotropy and heterogeneity on the fluid flow and heat transfer regime, Water Resour. Res., 32, pp. 32273235 .

Moridis, G., and K. Pruess (1995). Flow and Transport Simulations Using T2CG1, A Package of Conjugate Gradient Solvers for the TOUGH2 Family of Codes, LBL -36235, Lawrence Berkeley Laboratory, 118pp.

Parry, W.T., D. Hedderly-Smith, and R.L. Bruhn (1991). Fluid Inclusions and Hydrothermal Alteration on the Dixie Valley Fault, Nevada, J. Geophys. Res., 96, pp. 19,733-19,748.

Parry, W.T., P.N. Wilson, and R.L. Bruhn (1988). Pore fluid chemistry and chemical reactions on the Wasatch normal fault, Utah, Geochim. Cosmochim. Acta, 52, pp. 2053-2063.

Pruess, K. (1987). TOUGH User's Guide, LBL-20700, Lawrence Berkeley Laboratory, Berkeley, California, 78pp.

Pruess, K. (1991). TOUGH2-A General-Purpose Numerical Simulator for Multiphase Fluid and Heat Flow, LBL-29400, Lawrence Berkeley Laboratory, Berkeley, California, 102pp.

Pruess, K., S. Finsterle, G. Moridis, C. Oldenburg, and Y. Wu (1997). General-Purpose Reservoir Simulators: the TOUGH2 Family, Geothermal Resources Council Bulletin, 26:2, pp. 53-57.

Sorey, M.L., and F.H. Olmsted (1994). The Hydrothermal System Associated with Leach Hot Springs in Southern Grass Valley, Nevada, Geothermal Resources Council Transactions, 18, 31-36.

Vikre, P.G. (1989). Fluid-mineral relations in the Comstock lode, Econ. Geol., 84, pp. 1574-1613.

Welch, A.H., M.L. Sorey, and F.H. Olmsted (1981). The Hydrothermal System in Southern Grass Valley, Pershing County, Nevada, USGS Open File Report, 81-915, 193 pp.

Wisian, K.W. (1999). Numerical Modeling Basin and Range Geothermal Systems, Ph.D. Dissertation, $177 \mathrm{p}$.

Wisian, K.W. (2000), Insights into extensional systems from hydrothermal modeling, ed. E. Iglesias, D. Blackwell, T. Hunt, J. Lund, S. Tamanyu, and K. Kimbara, Trans. World Geothermal Congress 2000, 1947-1952.

Wisian, Kenneth W., David D. Blackwell, Numerical Modeling of Basin and Range Geothermal Systems, Geothermics, in press, 2003.

Wright, P.M. (1991). Exploration for new hydrothermal resources for electrical power generation in the 48 contiguous United States, Geothermal Resources Council Trans, 15, pp. 217-228.

Yeamans, F. (1983). Basin and Range Geothermal Hydrology: an Empirical Approach, in Geothermal Resources Council Special Report, 13, pp. 159-175. 


\section{Section 8. 2002 Geothermal Resource Potential Map - Construction and Explanation}

\subsection{Introduction}

The SMU Geothermal Lab was asked by the National Renewable Energy Laboratory (NREL) and US Department of Energy (DOE) to design a geothermal resource map that could be used on their websites and as part of informational publications. The result is a generalized geothermal resource map (Figure 8.1). With an audience of primarily K-12 students and teachers, state department personnel, and businesses, developing a general use map for a teaching/reference tool was the objective. Because of the availability on websites and in government publications, the 2002 Geothermal Resource Potential Map has been often cited (e.g., Kirby et al., 2002; Nielsen et al., 2003). Some explanatory notes on how the map was developed are discussed in this chapter.

The preparation of such a map is not straightforward and the criteria for preparing a geothermal resource map is complicated at best, especially compared to resource maps for other renewables such as wind and solar energy. Classifying geothermal energy is more like the cliché "the elephant - as examined by multiple blind men". There are multiple ways in which geothermal energy can be utilized and thus described. The complexity of these uses does not easily translate into a single map. In particular, these uses range from geothermal heat pumps (used almost everywhere), low to moderate temperature hydrothermal resources (nonelectric direct use), moderate and high temperature electrical resources (including Enhanced Geothermal Systems), geopressure, and in the classical sense Hot Dry Rock (HDR). Furthermore, almost all of these categories have gradations between them that are cost sensitive and location specific.

Clearly, to adequately represent complex geothermal systems, a map composed of many layers of information is required. Yet this complexity is not welcome by those outside of the geothermal field, they don't want too many conditions, or "if $\Rightarrow$ then" scenarios. Knowing this, the object was to produce a map easily readable with enough actual information to increase knowledge about geothermal resources and to generate ideas and questions in the minds of those who used it.

\subsection{Layers of the Map}

Our main research focus has been on mapping geothermal gradients and heat flow (Blackwell and Steele, 1992; Blackwell, et al., 1996). However, heat flow alone is not sufficient to show where geothermal resources are possible in the United States. High heat flow does not always extrapolate to usable geothermal resources in a one-to-one fashion, for instance, Yellowstone National Park has a high resource yet is regulated to prevent geothermal development. On the other hand, there are areas where average heat flow may furnish moderate temperature fluid for greenhouses, fish farms, and spas, etc.

The DOE 1979 map "Known Potential Areas for Geothermal Resources in the United States" was used as the starting point (Brophy, 1979). The first aim was to improve the level of detail from this previous map by building on the increased knowledge and data sources acquired from past geothermal exploration. The second goal was to emphasize where highest usages (electric power plants) are presently and where they could exist in the future. The third consideration was to include the general trends of low to medium geothermal resources through small scale direct applications that currently have a growing momentum in use. 


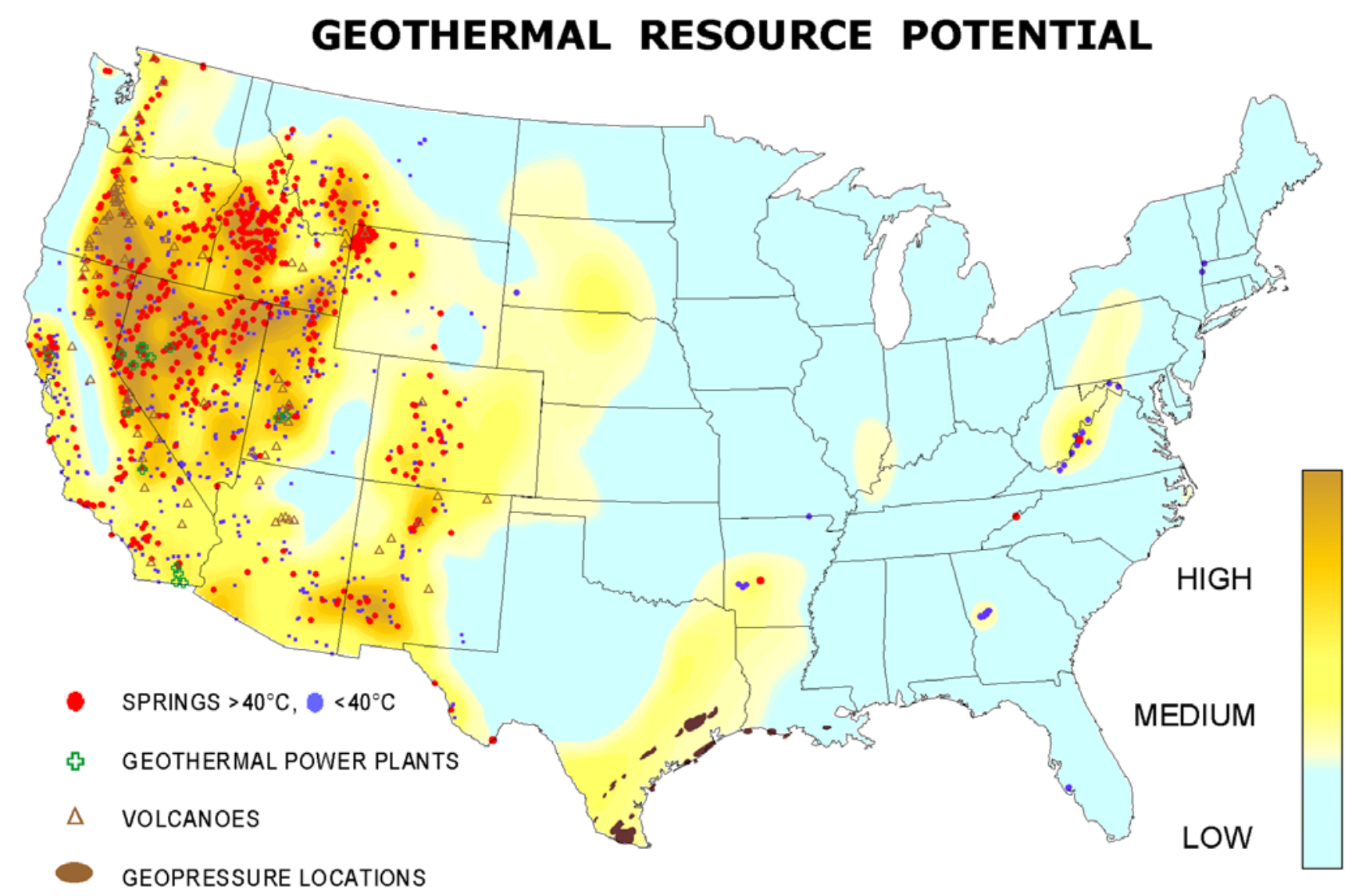

Figure 8.1. SMU Geothermal Resources Potential Map, 2002. 
In the broadest sense, geothermal energy utilization is the usage of the Earth's heat where it is elevated above normal groundwater temperatures. An extreme case of this, is the mining of the heat from the Earth to generate electricity. With this in mind, the map data were compiled from the following data sets including several not used before: the SMU Western Geothermal data base, the SMU United States Regional Heat Flow data base (www.smu.edu/geothermal), the Oregon Institute of Technology Low Temperature Geothermal data base (geoheat.oit.edu), the USGS Great Basin data base (http://wrgis.wr.usgs.gov/open-file/of99-425/webmaps/home.html), hot spring locations, Pleistocene and Holocene volcanoes, the geopressure areas along the Gulf Coast, the existing geothermal power plant locations, bottom hole temperatures (BHT) (AAPG, 1994), and sedimentary thickness maps (digitized from the AAPG Tectonic Map of North America, King, 1969). All of these data sets were factors used in configuring the 2002 Geothermal Resources Potential Map.

The BHT data were measured where drilling ceased in oil and gas wells. Some wells have three or more depths of BHT, i.e., at casing and logging points within one well. The AAPG data_rom contains data from over 20,000 wells. These were corrected for nonequilibrium effects and processed to determine geothermal gradients. Wells less than $600 \mathrm{~m}(2,000 \mathrm{ft})$ were omitted because the temperature is too influenced by surface temperature and drilling fluids for proper accuracy. For surface temperatures we used the Surface Groundwater Temperature Map (Gass, 1982). Thermal conductivity values were assigned according to the general area geology. The BHT wells were used in regions where little geothermal exploration data was available, thus they were concentrated along the Gulf Coast, and Illinois Basin - Michigan Basin. Other oil and gas exploration wells are available, but were not used in conjunction with this map.

The Bottom Hole Temperature data was then combined with the other geothermal data bases to calculate heat flow values. Locational heat flow values were gridded with minimum curvature and kriging - using a variogram for controlling the data. This heat flow grid became the new base map. From this base map, the rest of the layers were added. The first grid layer added was the hot springs and volcanoes. Hot springs were broken into three categories: $>80^{\circ} \mathrm{C},>40^{\circ} \mathrm{C}-<80^{\circ} \mathrm{C}$, and $<40^{\circ} \mathrm{C}$. The volcanoes were assigned the same grid value as the $>80^{\circ} \mathrm{C}$ hot springs. This was done since historic volcanic activity generally correlates with hot spring activity.

The second grid layer was sediment thickness. Using the Tectonic Map of North America, areas with greater than $2000 \mathrm{~m}(7,000 \mathrm{ft})$ of sediment were emphasized. At this depth greater amounts of heated fluids are possible, making these areas more likely to be a prospective geothermal resource. Constraints in the application of this layer were that the resulting configuration needed to agree with actual known temperature conditions. For example, it was important to keep Florida in the low geothermal resource potential level and yet have the Illinois Basin continue to be in the low to medium resource potential range based on the thousands of BHT data available. Similarly, the sediment layer weight for the Central Valley in California had to be lowered to match its low geothermal potential based on heat flow temperature data.

The last layer was composed of two disparate data sets, Hot Dry Rock and Geopressure. The Hot Dry Rock (HDR) areas are located primarily in the Appalachian Mountains, Louisiana and New Mexico; the geopressure areas are along the Gulf of Mexico and were based on the 1979 map.

\subsection{Geothermal Map Application}

Once all the layers were combined, the map (Figure 8.1) was then examined to make sure the broad categories of high - electric potential, medium - direct use, and low - heat pump geothermal potential were properly portrayed.

The majority of the eastern United States is considered to have low grade, but not zero, 
geothermal potential. A heat pump is an example of a low grade geothermal application. When considering the ability of a home owner or small business to use the local geothermal energy, there are few places in the United States that could not use geothermal heat for a heat pump or heat exchanger application.

Low to moderate grades of geothermal potential can be divided into multiple types of uses and methods for developing them. Where enough water and heat exist at moderate depths geothermal energy may be tapped for direct heating applications on a larger scale - industrial uses, large complex heating, under roads, etc. The majority of the western half of the United States is within this direct use category because of the elevated regional heat flow from increased tectonic activity. Outside the western U.S. there are specific sites, such as Hot Springs, Arkansas, that fit into the direct use category.

Developing a moderate geothermal energy source is also related to sedimentary basins. The sediments create a scenario where both higher temperatures and available fluids may exist because of the increased sediment depth. The Illinois Basin, eastern Texas, the Gulf Coast, and the Great Plains all are examples of this in the eastern U.S. Similar situations in the western U.S. occur in the Wyoming Basin, the Columbia Plateau, and the Colorado Plateau.

The Hot Dry Rock concept is still a long range moderate to high potential resource, because it is currently in still a development and trial production stage in the U.S. It is used as a current resource in other parts of the world. The HDR concept needs basement rock (or other tight formations) that can be fractured and a long term water source secured before the potential geothermal energy can be tapped. The Appalachians, northern Louisiana, and the eastern tip of North Carolina represent these areas.

Most of the southwestern Montana, Colorado and New Mexico (primarily the Rio Grande Rift region) have a medium to high potential for geothermal resource use. A mixture of faulting, sedimentary basins, and limited volcanic activity play an important role in the more site-specific geothermal resource potential of these areas. Most of the accessible volcanoes on the map are possible locations for medium to high-grade geothermal resources. The age, depth, and size of a magma body all are important factors as to the extent of potential geothermal resource today.

The high grade - electric potential geothermal resources are in the western U.S. The highest potential for geothermal resource utilization is located where groundwater can penetrate along natural pathways to deep depths and then return to shallow depths at temperatures of over $150^{\circ} \mathrm{C}$. This generally is found in areas associated with shallow magma bodies, which have heated the overlying rocks and fluids, or in areas of active faulting and fracturing in a high heat flow setting. Examples of where this occurs are The Geysers and Imperial Valley. Power plants are also located in areas with thinned continental crust and deep faulting, such as in the Basin and Range, i.e., Dixie Valley and Steamboat Springs. The potential for future power plants is in areas with high grade geothermal resources. The states within and bordering the Basin and Range Province, Oregon, California, Nevada, Idaho, Utah and Arizona are where this is most likely to occur. Development of high grade geothermal is very site specific. So although on the map the highest level area is delineated by dark blue, within and adjacent to this blue colored region will be a mixture of low to high grade potential geothermal sites. Similarly, areas outside the blue, there may be high geothermal potential prospects under a different scenario.

As with all energy potential, the geothermal potential must also consider the human impact on the resource. As energy demands and technology change, this could make direct use and heat pumps more common. Improved technology may also allow areas currently restricted for preservation to allow use of the resource as in the Cascades and Yellowstone. Another factor for development of the 
geothermal resource is the ability to transport the energy to where humans live.

\subsection{Future Work}

We are developing a new Geothermal Map of North America. This map will be based on more detailed geothermal information than the Geothermal Resource Potential Map shown here. The audience for this map is more focused towards the geothermal field and higher education. It will have multiple layers that can be added or subtracted by the individual in an interactive scenario. This ability to overlay different data sets will allow developers and explorationists to look at individual parameters to see how they interact and effect the regional and in some instances, the site specific geothermal anomalies.

The 2002 Geothermal Resources Potential Map is certainly not, and is not intended to be, the all encompassing geothermal answer. Geothermal is still where you find it! However, the map does show broadly where the potential for geothermal is in the United States according to the types of uses divided into low - heat pump, medium - direct use, and high - electric exploitation of the resources available. There are some site specific areas not necessarily shown with their maximum geothermal potential, as well as there are areas grouped within a higher than anticipated geothermal level. Until we have the ability to produce maps with small scale detail at a national resolution this will be an ongoing situation.

\subsection{References}

AAPG DataRom ADR1.2, Exploratory Well File (CSDE), Correlation file (COSUNA), Geothermal File (GSNA), produced by Masera-AAPG, 1994.

Blackwell, D.D. and J.L. Steele, eds., The Decade of North American Geology; Geothermal Map of North America, scale 1:5,000,000, Geological Society of America, Denver, Co., 1992.

Blackwell, D.D., K.W. Wisian, and M. Richards, Geothermal Resources of the United States based on heat flow and gradient information, Report for DOE contract \#C91-103450, 50pp., 1996.

Brophy, Paul, J.L. Renner, Tracy L. Vaught, Known Potential Areas for Geothermal Resources in the United States, Map 1:5,000,000, U.S. DOE Division of Geothermal Energy, 1979.

Gass, T.E., Geothermal heat pumps, Geothermal Resources Council Bulletin, 11, 3-8, 1982.

Kehle, R.O., R.J. Schoppel, and R.K. Deford, The AAPG geothermal survey of North America, U.N. Symposium on the Development and Utilization of Geothermal Resources, Pisa 1970, Geothermics Special Issue 2(1), 358-368, 1970.

King, Phillip, Tectonic Map of North America, USGS 1:5,000,000, 1969.

Kirby, Mike, Doug Dahle, Donna Heimiller, Barbara Farhar, and Branndon Owens, Assessing the potential for renewable energy on public lands, U.S. Department of the Interior, Bureau of Land Management and U.S. Department of Energy, Energy Efficiency and Renewable Energy, contract DOE/GO-102003-1704, p. 95, 2003 (web address).

Nielsen, John, Susan Innis, Leslie Kaas Pollock, Heather Rhoads-Weaver, and Angela Shutak, Renewable Energy Atlas of the West: A guide to the region's resource potential, published by Land and Water Fund of the Rockies, p. 81, 2002.

Reed, M.J., ed., Assessment of low-temperature geothermal resources of the United States-1982, U.S. Geol. Surv. Circ. 892, 73 pp., 1983.

Richards, Maria and David Blackwell, Geothermal Resource Potential Map, Geothermal Resources Bulletin, 32, July, 2003.

Sass, John, Great Basin geothermal, Geothermal Council Bulletin, vol. 30, no. 5, p. 195-197, September/October 2001. 


\section{Section 9. Brief Explanation of the Geothermal Map of North America, 2003}

\subsection{Introduction}

Preliminary activities related to the production of a new geothermal map of North America have been part of this project. There are two main aspects of the activity, the collection and preparation of the various data sets and the drafting of the preliminary versions of the map. The last Geothermal Map of North American was prepared in the late 1980's. It was published in 1992 by the Geological Society of America (GSA) (Blackwell and Steele, 1992) in conjunction with the GSA sponsored Decade of North American Geology (DNAG). The map featured research data (about 3000 points) and served as the basis of several geothermal evaluation projects.

In this project the objective was to utilize extensive industry oriented thermal data sets, as well as the research heat flow data. To that end the 6000 point Western Geothermal Database was analyzed for use in preparing this map. Although there was very little heat flow data in the industry reports and publications, consistenting mostly of raw temperature-depth and gradient information, we determined thermal conductivity, rated quality, and calculated heat flow for as many of the wells as possible. These data have been used in the preparation of the new map (about 4000 points were used of the 6000 in the database). The second main data set was the 20,000 plus Bottom Hole Temperature (BHT) data set compiled by the AAPG in the early 1970's.

\subsection{Geothermal Data Incorporated}

This map uses both industry data and research quality thermal data, as opposed to only the thermal data on the 1992 GSA Map. There are about 20,000 points processed BHT sites on the map, about 4,000 thermal gradient well sites, and about 3,000 conventional heat flow sites (for the US). The map data were compiled from the following data sets including several not used before: the SMU Western Geothermal data base, SMU United States Regional Heat Flow data base (www.smu.edu/geothermal), USGS Great Basin data base (http:/wrgis.wr.usgs.gov/open-file/of99425/webmaps/home.html), North American hot springs, Pleistocene and Holocene volcanoes, and bottom hole temperatures, (BHT) (AAPG, 1994). The various data sets have been processed as described in the following paragraphs.

The BHT data have been corrected based on the AAPG BHT correction as used by Harrison et al. (1983). Data up to a maximum depth of $3,000 \mathrm{~m}$ were used $(4,000 \mathrm{~m}$ in southern Louisiana). This correction was checked against about 30 sites in the western US with accurate thermal logs. We believe the correction for gradient to be good to about $\pm 5 \%$ based on direct comparisons. Although there are data in areas to depths of $6,000 \mathrm{~m}$, the depth was limited to those less than $4,000 \mathrm{~m}$, due to the uncertainty of the BHT correction with increasing depth. Simplified thermal conductivity models were used for specific geographic areas to convert the BHT gradients to heat flow. The results were checked against conventional heat flow measurements for general agreement. The areas in which the BHT data were used are shown in Figure 9.1.

BHT data also exist for the Illinois Basin and areas in the western US that were not used because of the unknown thermal conductivity distribution there. Because of the way we processed the BHT data, the small-scale variations in these areas might or might not reflect actual crustal heat flow variations. Lateral small-scale variations in the stratigraphy will cause errors in the thermal conductivity estimation, and thus the depicted heat flow calculations from BHT data. Local heat flow variations (vertically and horizontally) at the kilometer scale due to small scale effects such as water flow was another concern, (larger scale effects of this sort have been captured as described in literature). 


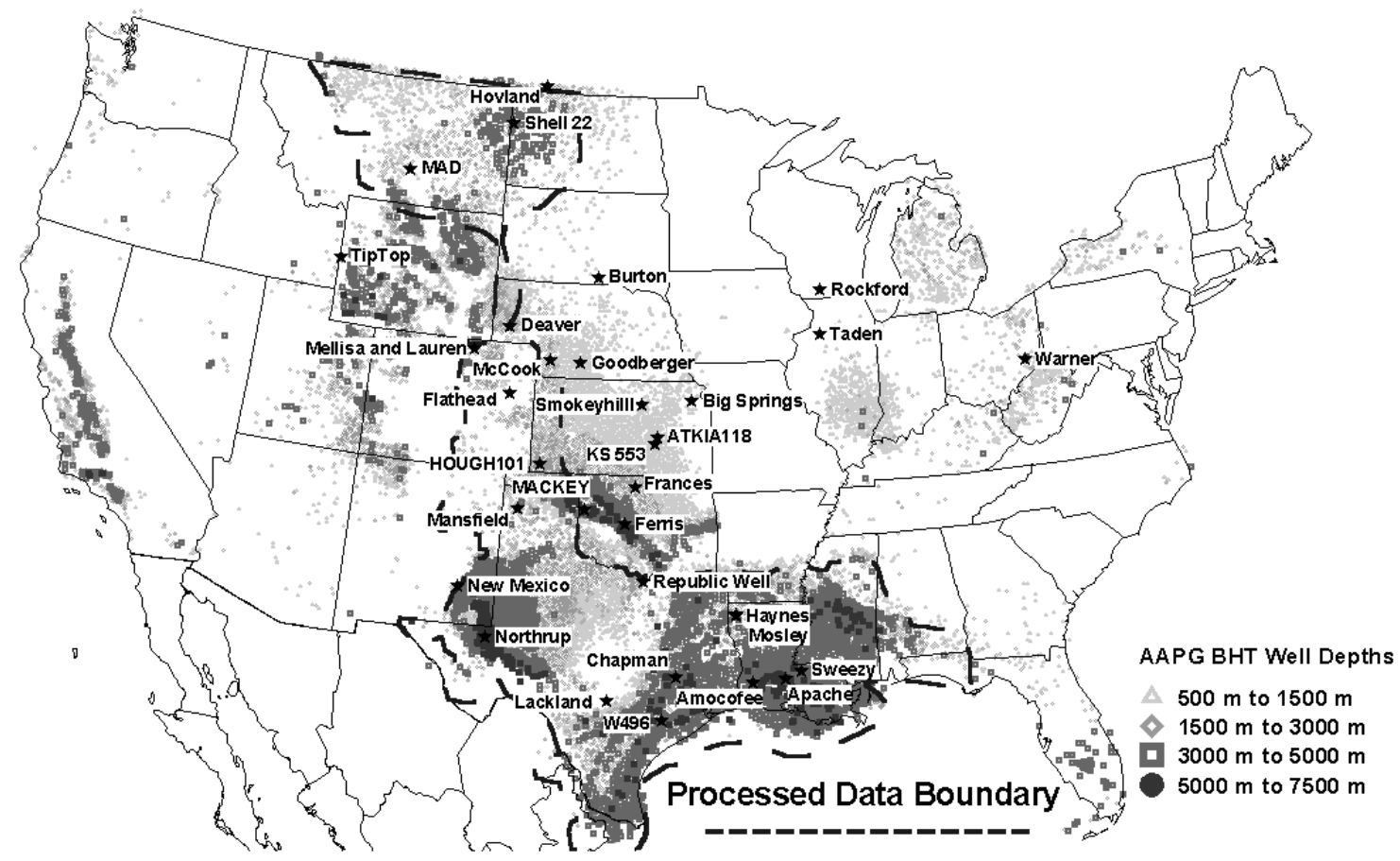

Figure 9.1 AAPG BHT locations of data and SMU thermal deep wells used for comparison.

Also used in the preparation of the contour map were the data from the newly established Western Geothermal Database. These collected and processed heat flow data derived from thermal gradient exploration wells drilled primarily for geothermal resources exploration in the western US, generally during the time frame of 1975 to 1985 . These data are available on the SMU Geothermal web site. The raw data were processed to calculate heat flow for many of the sites. There are site/well specific thermal conductivity data for about $50 \%$ of the sites. In the Basin and Range, most of the sites are in the valley fill. Thermal conductivity was assumed for these wells based on lithology logs or, in the absence of even this data, on the basis of well site geology from maps. Many more well sites in the collected data bases have gradient values than measured thermal conductivity values. When determining the North American heat flow, these sites were not used unless detailed lithologies were available to assign reasonable thermal conductivities for the location. There are about 5,000 sites in the data base. These sites are concentrated in western Nevada and southwestern Utah.

\subsection{Contouring}

Sites were assigned a quality ranking based on the drilled depth and the quality of the data. Wells deeper than 25 meters were examined. Deeper wells received higher quality rankings and on a regional basis only wells deeper than $100 \mathrm{~m}$ were used. The general ranking criteria are described by Blackwell et al. (1991). Wells with "geothermal" scale gradients/heat flow or those drilled within a known geothermal area are given a separate ranking. Plotted heat flow values by symbol on the map are for regional wells. A cut off heat flow of $120 \mathrm{mWm}^{-2}$ was used to differentiate "geothermal" versus "regional" sites. The geothermal wells are plotted as a dot because of the well concentration and wide variance in gradients within a small area.

All of the values considered regional from the Western Geothermal, Regional Heat Flow, and the USGS Great Basin data bases were merged into a single file and contoured using a minimum curvature algorithm with a tension factor of 0.8 , averaging all points within a $0.02^{\circ}$ spacing of each 
other, and a grid interval of $5^{\prime}\left(0.08333^{\circ}\right)$ of latitude/longitude. Points were added to constrain the contours to follow structural/province trends in areas of sparse data coverage. This process changes the details of the map but all major features are reasonably resolved without this manipulation of the data contours.

Heat flow contour levels are increased from $10 \mathrm{mWm}^{-2}$ on the 1992 map to $5 \mathrm{mWm}^{-2}$. With the increased number of heat flow points, the knowledge of heat flow levels has improved. This amplifies the detailed information for a region. By using colors and contours that blend from one interval to the next, it also is designed to show the heat flow values for specific areas where detailed information is known, i.e., the Basin and Range, but still allow for the greater generality in places with little to no specific data, i.e., Kentucky. The overall heat flow contouring represents the regional heat flow levels of North America. Although, where the geology, tectonics, and data represent more specific area detail, we have contoured it accordingly.

New heat flow locations are now available - especially in Canada from new exploration, and in Western United States where data were previously proprietary. Other areas with new data are the oceans and Costa Rica, these can be found at www.und.edu/org/ihfc/index2.html and www.smu.edu/geothermal.

\subsection{Map Features for 2003 compared to 1992}

The size of the map is decreased from four sheets totaling 70" x 70" to one sheet 48 " x 63 " to make this map more manageable. The map will be printed by the Kansas Geological Survey and marketed and sold through the American Association of Petroleum Geologists (AAPG). The goal is to increase the interest in and knowledge of the Geothermal Field by having more heat flow maps in classrooms and on office walls, as well as online access to the location of geothermal data.

Along with the map, additional layering information will be available that can be integrated into Geographic Information Systems (GIS). Examples of other map layers that will be available are:

- Heat flow data locations using symbols to show individual values

- Geothermal Areas - grouped into maximum temperature bins of $>150^{\circ} \mathrm{C}$, and $75^{\circ} \mathrm{C}-149^{\circ} \mathrm{C}$

- Existing geothermal power plant locations

- Pleistocene and Holocene Volcanoes

- Hot Springs

- Plate Tectonic features - transform faults, subduction zones, and oceanic ridges

- Geopressure areas

- Aquifer recharge and discharge areas

\subsection{References}

AAPG, American Association of Petroleum Geologist, CSDE, COSUNA, and Geothermal Survey Data_Rom, 1994.

Blackwell, D. D., and J. L. Steele, Geothermal Map of North America, 1:5,000,000, Geological Society of America DNAG Map Series, 1992

Blackwell, D.D., J.L. Steele and L.S. Carter, Heat flow patterns of the North American continent: A discussion of the DNAG geothermal map of North America, pp. 423-437, in D.B. Slemmons, E.R. Engdahl, and D.D. Blackwell eds., Neotectonics of North America, Geological Society of America. DNAG Decade Map Volume 1, pp. 498, 1991.

Harrison, W.E., K.V. Luza, M.L Prater, and P.K. Chueng, Geothermal resource assessment of Oklahoma, Special Publication 83-1, Oklahoma Geological Survey, 1983. 


\section{Section 10. Data Sources and Resources}

\subsection{Website details}

The Southern Methodist University, Department of Geological Sciences Geothermal Laboratory maintains the website www.smu.edu/geothermal. It is used by industry, students and educators, government agencies, and home owners. The information is designed to be general enough to meet the needs of those who know little about geothermal by leading them to other websites that may be more helpful for class reports, heat pumps, etc,. For those working in the industry there are very specific data information and tutorials for improving exploration techniques.

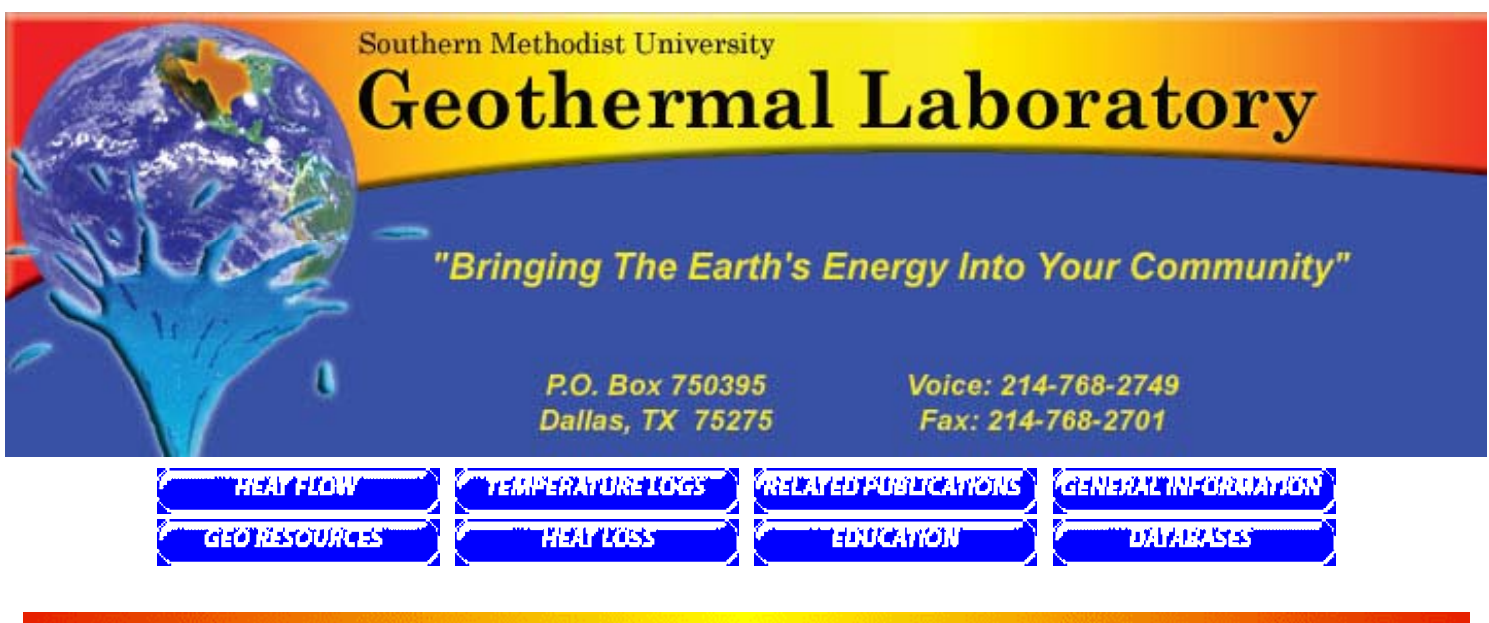

* Exploration of potential Geothermal Resources,

* Resource Assessment of existing Geothermal fields,

* Expansion and Maintenance of two Thermal Databases,

* Mapping of Geophysical data on Local and Regional levels,

* Analysis and Modeling of Geothermal Systems,

* Thermal Modeling of Oil and Gas fields,

* Examination of Plate Tectonic Processes,

* On-site Borehole Temperature - Depth Logging,

* Determination of Thermal Conductivity of rock samples.

Quick Links:

SMU Department of Geological Sciences

The National Geothermal Education Office (K-12 information for students and teachers)

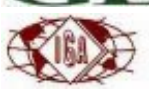

International Geothermal Association

The contents of this web page are the sole responsibility of the SMU Geothermal Lab and its contributors. They do not necessarily represent the opinions or policies of Southern Methodist University. The administrator of this web page is Maria Richards who may be contacted at mrichard@mail.smu.edu. 


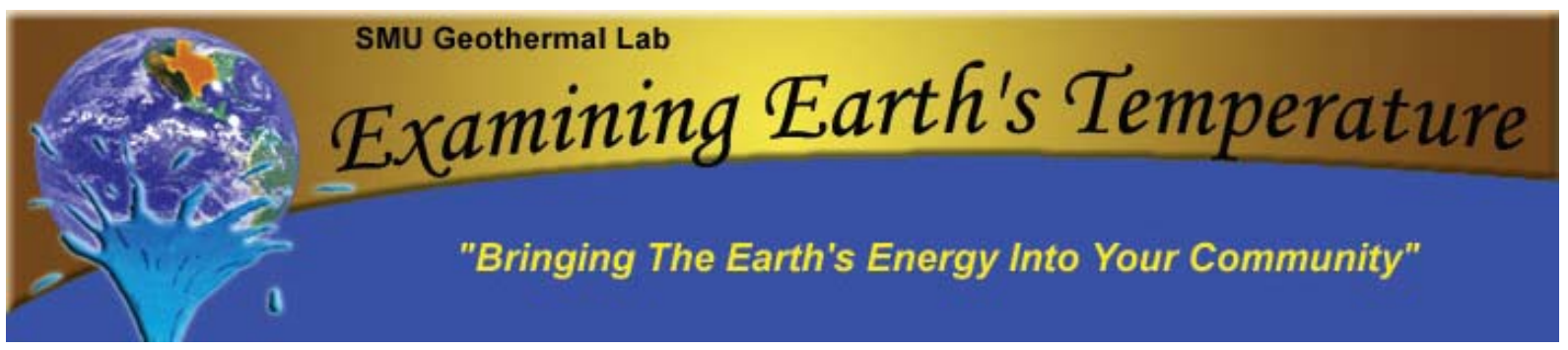

\subsection{Temperature -Depth Logging Tutorial}

This tutorial has consistently been one of the highest activity levels on the website. It is designed to educate people on how to interpret temperature information found in well logs. The information is a combination of out-of-print articles and colored graphs that explain what to look for and how to determine what the wiggles and bends mean in a temperature log. Figure 10.1 below is an example from the tutorial on the website. There are 34 such examples given within the nine categories of geologic structure. http://www.smu.edu/geothermal/temperat/temperat.htm

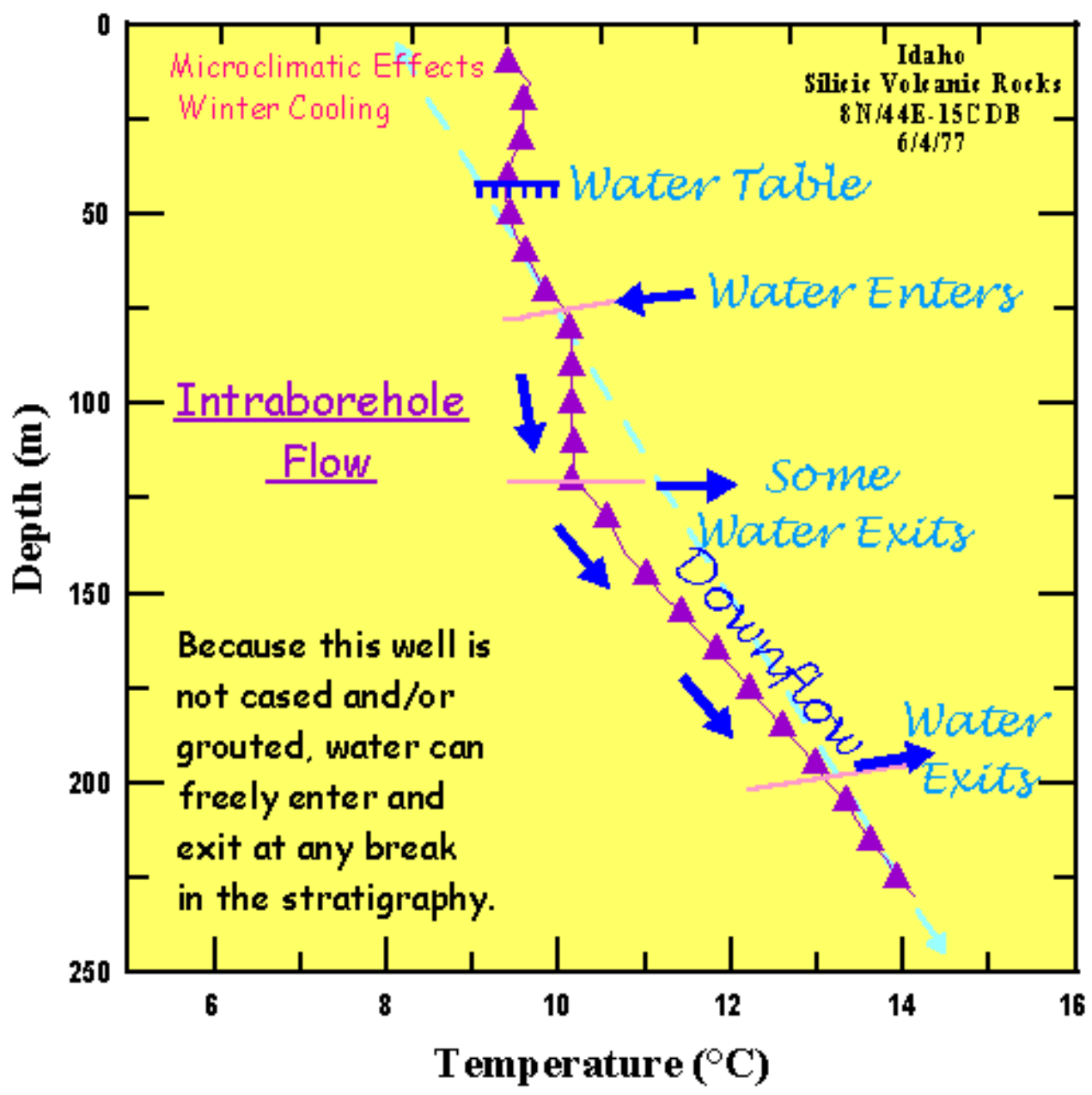

Figure 10.1. Example of Interbore hole flow within a well and its surrounding formation. This is one of nine categories that have similar temperature -- depth curves shown with instructive information about how to interpret what is found. 


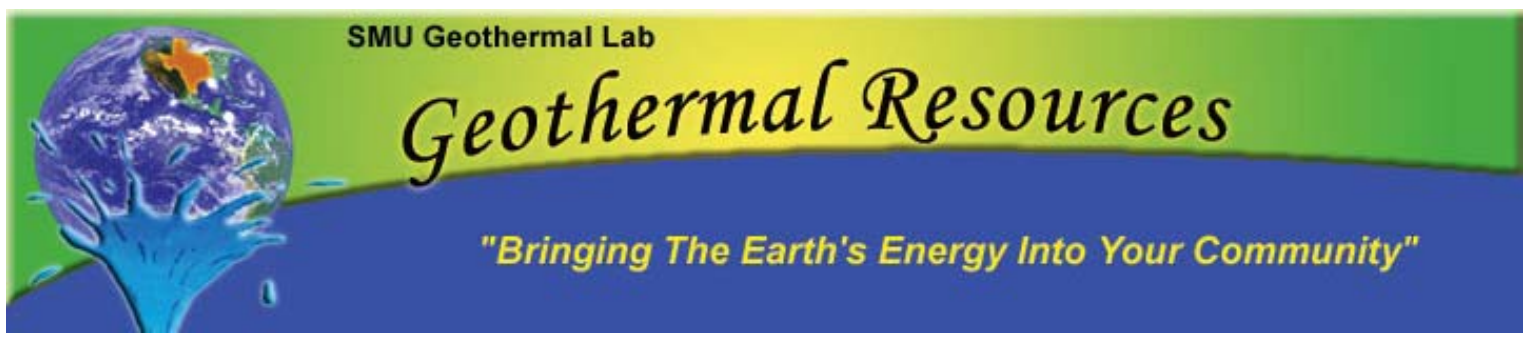

\subsection{Geothermal Resources}

This portion of the website (www.smu.edu/geothermal/georesou/Geo_openingpage.htm) is designed to be instructive in the what geothermal resources are available through SMU and other agencies. It highlights the two databases described below, and how this information is then used for research and to create maps. We are pleased that daily people download the data base files. This is a resource not only for the geothermal exploration field in the United States, but for individuals, students, government agencies throughout the world.

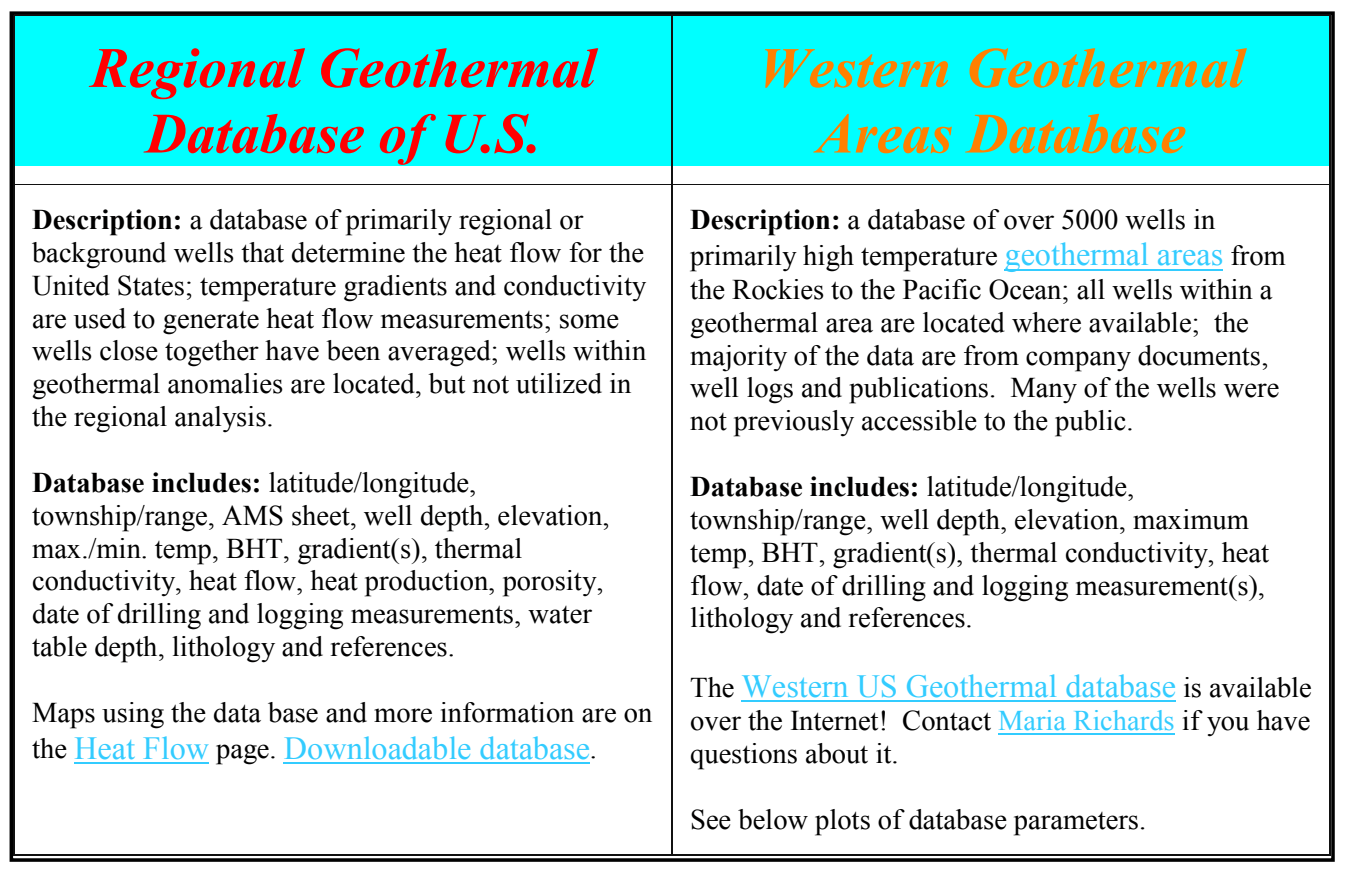

\section{Companies with Significant Contributions to Database}

\begin{tabular}{|l|l|l|l|}
\hline AMAX & Aminoil USA & Oxy Geothermal & NuFuels \\
\hline Gulf & Chevron & Earth Power Production Co. & Phillips \\
\hline Ensearch & Union Geothermal & Transpacific Geothermal & Getty Oil \\
\hline Hunt & Anadarko Petro. & Southland Royalty & Sunoco \\
\hline
\end{tabular}

\subsection{Reference List}

The complete data base references are available on the website www.smu.edu/geothermal/georesou/alldata.htm. There is a reference list for both of the SMU data bases described above with over 500 references listed. To conserve paper and we did not print them. 


\section{Section 11. Publications}

Benoit, Dick, Randy Norman, Colin Smithpeter, Steve Thompson, David Blackwell, Design, fabrication, installation, and testing of an advanced wellbore/reservoir monitoring system at the Dixie Valley, Nevada geothermal field, Twenty Forth Workshop on Geothermal reservoir Engineering, Stanford University, v 24, 319-324, 1999.

Blackwell, D.D., B. Gollan, and D. Benoit, Temperatures in the Dixie Valley, Nevada geothermal system, Geothermal Resources Council Trans., 24, 223-228, 2000.

Blackwell, D.D., B. Gollan, and D. Benoit, Thermal Regime in the Dixie Valley, Nevada geothermal system, ed. E. Iglesias, D. Blackwell, T. Hunt, J. Lund, S. Tamanyu, and K. Kimbara, Trans. World Geothermal Congress 2000, 991-996, 2000.

Blackwell, David D., Grame R. Beardsmore, Richard K. Nishimori, and Richard J. McMullen, Jr., High-resolution temperature logs in a petroleum setting: examples and applications, Geothermics in Basin Analysis, edited by Förster and Merriam, Kluwer Academic/Plenum Pub., 1 -34, 1999.

Blackwell, D.D., K.W. Wisian and M. Richards, Heat Flow / Thermal Gradient Exploration in the Western United States and the Evaluation of Geothermal Systems, Proceedings of the World Geothermal Congress 2000, CD-ROM, 2000.

Blackwell, D.D., K.W. Wisian, D Benoit, and B. Gollan, Structure of the Dixie Valley Geothermal System. a "typical" Basin and Range Geothermal System, from thermal and gravity data, Geothermal Resources Council Transactions, 23, 525-531, 1999.

Blackwell, D.D., K.W. Wisian, J.R. McKenna, Geophysical and geological models of the structure of normal faulting in Dixie Valley, Nevada, draft paper for submission to Jour. Geophys. Res., 2002.

Blackwell, David D., Mark Leidig, and Richard P. Smith, Regional Geophysics of the Dixie Valley Area: Example of a Large Basin and Range Geothermal Resource, Geothermal Resources Council Trans., 26, 519-522, 2002.

Blackwell, David D., Mark Leidig, Richard P. Smith, Stuart Johnson and Kenneth W. Wisian, Exploration and Development Techniques for Basin and Range Geothermal Systems: Examples From Dixie Valley, Nevada, Geothermal Resources Council Trans., 26, 513-518, 2002.

Blackwell, D.D., M. Richards, K.W. Wisian, and J.L. Steele, System specific geothermal gradient/heat flow database for the western United States, Geothermal. Res. Council Trans., 23, 461-466, 1999.

Bowers, R., R. Cunniff, M. Leidig, and D.D. Blackwell, Geophysical exploration in the Animas area, draft report to DOE, 2002.

Brikowski, T., D. Norton, and D.D. Blackwell, Natural state modeling The Geysers geothermal system, Final Report, DOE Contract DE-FG07-98ID13677, 20 pp., 2001.

Gallardo, J. and D.D. Blackwell, Thermal structure of the Anadarko Basin, Oklahoma, Bull. Amer. Assoc. Petrol. Geol., 83, 333-361, 1999.

Kelley, Shari A. and David D. Blackwell, Subsurface temperatures in the southern Denver Basin, Colorado, Rocky Mountain Geology: Paleontology and Stratigraphy of Laramide Strata in the Denver Basin (Part I), 37, 2, 215-227, 2002.

McKenna, J.R. and D.D. Blackwell, Thermal regime of a large mid-continent oil field (Butler County, Kansas) from high-resolution temperature logs, Oklahoma Geol. Sur. Circ., 106, 149-159, 2002. 
Richards, Maria and David Blackwell, The Forgotten Ones: Geothermal roads less traveled in Nevada, Geothermal Bulletin, v. 31, no. 2, 69-75, 2002.

Richards, Maria and David Blackwell, The Nevada Story- turning a loss into a gain, Geothermal Resources Bulletin, v. 31, no. 3, 107-110, 2002.

Richards, Maria and David Blackwell, A Difficult Search, Why Basin and Range systems are hard to find, Geothermal Bulletin, v. 31, no. 4, 143-146, 2002.

Richards, Maria and David Blackwell, Montana, waiting to be discovered, Geothermal Resources Bulletin, v. 32, no. 1, 35-37, 2003.

Richards, Maria and David Blackwell, Geothermal Resource Potential, Geothermal Resources Bulletin, v. 32, no. 3, in print, 2003.

Smith, R.P., K.W. Wisian, and D.D. Blackwell, Geologic and geophysical evidence for intra-basin and footwall faulting at Dixie Valley, Nevada, Geothermal Resources Council Trans., 25, 323-330, 2001.

Smith, R.P., V.J.S. Grauch, and D.D. Blackwell, Preliminary results of a high-resolution aeromagnetic survey to identify buried faults at Dixie Valley, Nevada, Geothermal Resources Council Trans, 26, 543-546, 2002.

Wisian, K.W., Numerical modeling of Basin and Range geothermal systems and other geophysical studies, PhD Dissertation, Southern Methodist University, 165 pp., 1999.

Wisian, K.W., Insights into extensional systems from hydrothermal modeling, ed. E. Iglesias, D. Blackwell, T. Hunt, J. Lund, S. Tamanyu, and K. Kimbara, Trans. World Geothermal Congress 2000, 1947-1952, 2000.

Wisian, Kenneth W., David D. Blackwell, Numerical Modeling of Basin and Range Geothermal Systems, Geothermics, in press, 2003.

Wisian, K.W., D.D. Blackwell, and M. Richards, Heat flow in the western U. S. and extensional geothermal systems, Proceedings, 24 ${ }^{\text {th }}$ Workshop on Geothermal Reservoir Engineering, Stanford University, Stanford, CA., 219-226, 1999.

Wisian, K.W., D.D. Blackwell, and M. Richards, Correlation of surface heat loss and total energy production for geothermal systems, $5^{\text {th }}$ International Workshop on Heat Flow and the Lithosphere Structure, Geophysical Institute, Academy of Sciences of the Czech Republic, 2001.

Wisian, Kenneth W., David D. Blackwell and Maria C. Richards, Correlation of surface heat loss and total energy production for geothermal systems, Geothermal Res. Council Trans., v. 25, 331$336,2001$. 